\title{
The Origins of Roman Christian Diplomacy
}

This book illuminates the origins of Roman Christian diplomacy through two case studies: Constantius II's imperial strategy in the Red Sea and John Chrysostom's ecclesiastical strategy in Gothia and Sasanian Persia.

Both men have enjoyed a strong narrative tradition: Constantius, as a persecuting, theological fanatic; and Chrysostom, as a stubborn, naïve reformer. Yet this tradition has often masked their remarkable innovations. As part of his strategy for conquest, Constantius was forced to focus on Alexandria, demonstrating a carefully orchestrated campaign along the principal eastern trade route. Meanwhile, while John Chrysostom's preaching and social reform have garnered extensive discussion, his late sermons and letters composed in exile reveal an ambitious program to establish church structures outside imperial state control.

The book demonstrates that these two pioneers innovated a diplomacy that utilized Christianity as a tool for forging alliances with external peoples - a procedure that would later become central to Byzantine statecraft. It will appeal to all those interested in early Christianity and late antique/medieval history.

Walter Stevenson is Associate Professor of Classical Studies at the University of Richmond, Virginia. His research interests include early Christianity, Roman history, and ancient literature. 
$\because$ Taylor \& Francis

Taylor \& Francis Group

http://taylorandfrancis.com 


\section{The Origins of Roman Christian Diplomacy}

Constantius II and John Chrysostom as Innovators

\section{Walter Stevenson}

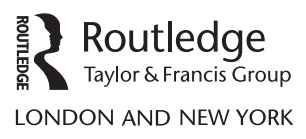


First published 2021

by Routledge

2 Park Square, Milton Park, Abingdon, Oxon OX14 4RN

and by Routledge

52 Vanderbilt Avenue, New York, NY 10017

Routledge is an imprint of the Taylor \& Francis Group, an informa business

(C) 2021 Walter Stevenson

The right of Walter Stevenson to be identified as author of this work has been asserted by him in accordance with sections 77 and 78 of the Copyright, Designs and Patents Act 1988.

All rights reserved. No part of this book may be reprinted or reproduced or utilised in any form or by any electronic, mechanical, or other means, now known or hereafter invented, including photocopying and recording, or in any information storage or retrieval system, without permission in writing from the publishers.

Trademark notice: Product or corporate names may be trademarks or registered trademarks, and are used only for identification and explanation without intent to infringe.

British Library Cataloguing-in-Publication Data

A catalogue record for this book is available from the British Library

Library of Congress Cataloging-in-Publication Data

A catalog record for this book has been requested

ISBN: 978-1-138-21946-5 (hbk)

ISBN: 978-1-315-41501-7 (ebk)

Typeset in Times New Roman

by Apex CoVantage, LLC 
To the Memory of My Very Dear Parents 
$\because$ Taylor \& Francis

Taylor \& Francis Group

http://taylorandfrancis.com 


\section{Contents}

Preface

1 Approaching Roman Christian diplomacy in context

Challenges to understanding: "religion" 2

Challenges to understanding: "secular" 3

Challenges to understanding: church and state 4

Challenges to understanding: Constantine as symbol

of Christian imperialism 6

The case for Constantine's mission to the Goths 7

Constantine's plan to Christianize Persia 11

Other historiographical challenges 11

Plan of the book 14

2 Mission to Himyar and Aksum in context

Literary source one: Philostorgius narrates the story 20

Excursus: the importance of the Indian Ocean trade route 22

Literary source two: Rufinus on Christianization of Aksum 23

Literary source three: Constantius's letters to Aksum and Alexandria 25

Summary of literary sources 26

The route: precedents 27

Logistics and reconstructing the actual route 28

Reconstruction of literary and logistical sources 29

Perceptions of the Himyarites 31

Perceptions of the Aksumites 31

Perceptions of the Alexandrians 32

Concluding perceptions of Constantius 32 
viii Contents

3 Constantius's bishop management program

Constantine's record on episcopal banishment 44

Constantius forced to innovate by circumstances:

Bishop Paul in Constantinople 48

A first politically successful exile: Paulinus of Trier 50

A western purge: Dionysius of Milan, Eusebius of Vercelli,

and Lucifer of Cagliari 51

New approaches to eliminating political enemies:

Liberius of Rome, Hilary of Poitiers, Hosius of Corduba 53

The staged deposition of Athanasius 57

Non-Nicene episcopal exiles: Eudoxius, Basil, and Eustathius 57

4 Constantius's bureaucracy abroad

Constantius's addressee Strategius Musonianus 73

Constantius creates a network of agents in the 350s 78

Speculation on the missions of these agents traveling to the Red Sea 85

Chronological and textual problems in CTh 12.12.2 86

Aims and perceived dangers inherent in the act of promulgating the edict 89

Christian mission in Constantius's Red Sea policy 90

5 John Chrysostom's mission to Gothia

Why so cosmopolitan? Exotic ethnic lists as guides to action 108

Eudoxia as patroness 112

6 Marouta of Maiferqat and the mission to Persia

Chrysostom and Marouta 120

Sasanian innovation in religious policy 124

Why was John Chrysostom the first bishop to plan a mission to Persia? 128

Syriac-speaking Christianity and Antioch's

exceptionalism 128

Influence of Marouta and Sasanian policy on John? 131

Some concluding ruminations on John's ecclesiastic

diplomacy 131 
8 First steps toward a new Christian diplomacy

Case studies 160

Criterion one: potential for success 162

Criterion two: personnel choices 164

Criterion three: linguistic ability 166

Criterion four: cultural literacy 166

Criterion five: source of origination 169

Criterion six: logistical complexity 169

Criterion seven: religion 170

Conclusions 171

9 Byzantine trajectories

Changing diplomatic world: Vandal North Africa 180

Justinian's diplomacy in the Red Sea theater 184

Justinian and the Black Sea theater 189

Justinian's mission to Nubia 191

The conversion of Rus' 194

Index 


\section{Preface}

A diverse but vivid audience engaged my imagination as I composed this book: colleagues in other fields like anthropology, linguistics, mathematics, modern history, political science, and so on; the many intelligent people that I chat with at auto repair waiting rooms, coffee shops, tailgates, funerals, and wedding receptions; book clubs and church/mosque/synagogue groups; my administrators; confident left and right wing editorialists; and family members. In the United States we live in an odd but not unwelcome cultural moment where the (tenured) professor, a relatively well-paid member of society who spends time writing on "academic" topics, anxiously ponders: one, the desire to reach past the dozen readers in a welldefined field; and two, the necessity of public outreach for survival of that field. Accordingly, I have made a concerted effort not only to make recondite material accessible but also to make it attractive to my curious and educated fellow humans. Not that I pretend to have successfully solved the problem often called, somewhat superciliously, "responsible popularizing" in the contemporary academy, but rather, I am defending what some will condemn as the breezy style of the learned essayists of the Anglo-American tradition.

This essayist strategy forces me to turn to my specialist colleagues and deliver a brief defense. I am aware from decades of reading academic referee reports that you are passionate about defending the dignity of your field, the virtues of recent scientific progress, and the careers of those who excel therein. I understand and welcome your dissatisfaction at having an outsider skim the cream, often sloppily, from your vat to make a crowd-pleasing cheese, one that leaves a cloying aftertaste in your mouth. I can only hope that someone from each subfield will pay this book the compliment of attacking the many distortions and lacunae required for the accessible, synthetic style of this book. I am speaking of African studies, Byzantine studies, ethnic studies, frontier studies, Gothic studies, historiography (Ammianus, cultural historians, diplomatic historians, ecclesiastical historians, intellectual historians), Iranian studies, patristics, Syriac studies, theology, and each area's subfields in archaeology, epigraphy, history, numismatics, and philology. I made an effort to read as widely as possible in your fields in the hope that this synthetic book might bring more attention to your work, work that I believe passionately deserves a much broader audience. And I took on the voice of an expert lecturer, not to pretend to lofty expertise, but rather, to avoid the tedium of a relentlessly 
cautious academese - "it is perhaps plausible to guess ...," "apparently . ..," "perhaps one could conjecture ...," and so on.

I have indulged in discussions of method throughout the book. Once again, the practitioners of many well-developed fields of modern academic theory will be dismayed by the "reductionist" approach I take. My defense here is twofold: one, my graduate education occurred in the 1980s amid enormous enthusiasm for, and formal attention to, theoretical musings on method, in which I participated fervently; and two, this book's analyses were self-consciously constructed to heed theoretical teachings while retaining accessible language and brevity. Let me try to explain this with an example.

The productive recent focus on embodiment in the study of antiquity, among many others, nourished this book. Though most of this work has been directed toward illumination of gender and toward a healthy antidote to the somewhat hidden but surprisingly prevalent ingredient of mind-body or spirit-body duality in human tradition, ${ }^{1}$ I made the effort to apply this theoretical approach to ancient history. Many students of antiquity will spend a satisfying 10 minutes at a conference discussing the challenges of traveling from Austin, Texas, to Berkeley, California. Not many things bring more awareness to the body than bloodshot eyes, cricked necks, aching lumbar regions, cramped knees, and throbbing feet. In this book I frequently tried to extend the reader's attention from lofty thoughts of Roman diplomatic theory to the challenges of traveling from Antioch to Ethiopia that is, to the corporeal demands of thirst, hunger, and heat as well as the tangible requirements of shelter and transport. This focus on the physical extends to frequent considerations of material remains and all their ramifications for how embodied life was lived, especially on the eastern fringes of the Roman world. One reader's low tolerance for perceived tediousness will with any luck be balanced by another reader's appreciation for understanding the embodied world of late Roman diplomacy.

With this apology humbly delivered, I turn to the content of the topic at hand. The study of Roman diplomacy begins from the truism that the high Roman Empire communicated with its neighbors through military threat and violence, until the 3rd century CE brought Rome its first military equals, Goths and Sasanids, and the 4th century introduced disasters like the Gothic victory at Adrianople and frequent defeats due to superior Hunnic cavalry. Realizing that military might could be used more effectively in a framework of diplomacy, the Romans gradually developed a diplomatic machine that reached its tangible climax with the Byzantine emperor Constantine VII's published works, the De administrando imperio and De caeremoniis, describing the elaborate workings of a mature, professional state diplomacy. From these 10th-century classics, through early-modern treatises, ${ }^{2}$ to the present, ${ }^{3}$ the practical necessity of diplomatic training based on past experience has kept the topic front and center. Though I could enter into a complex discussion of how the above wide array of modern academic fields has stunted a discussion of the role of Christianity in the development of Western diplomacy, I would rather let the inherent interest of the topic speak for itself. 
Finally, I would like to publicly thank the many people who have knowingly or unknowingly supported this work. I can sincerely and emphatically say that none of these people should share in any of the criticisms or blame for failings that inevitably will follow publication. I have enjoyed the support of my colleagues on the University of Richmond Faculty Research Committee, the Gloria Wills foundation, the library at Dumbarton Oaks, and the amazing University of Richmond Interlibrary Loan Department. My students, both at the University of Richmond and at the Ukrainian Catholic University, have been a constant inspiration and stimulus to me over the years. Thanks need to go to Dumbarton Oaks Papers for allowing me to reuse significant parts of my article published there in Chapter $3 .^{4}$ Innumerable colleagues were involved in conversations, criticisms, and suggestions in the writing of this book, but I reserve the place of honor for one central figure. As a professional classicist, I came to the late antique world on my own 25 years ago and suffered all the misfortunes that an academic orphan deserves. But through it all, Susan Harvey has believed in me, supported me, and pushed me onward. I owe a special debt of gratitude also to my editor, Michael Greenwood, who likewise stuck with me through delays caused by my often turbulent life. Last of all, but most important, I have been blessed with more supportive families than any single person could deserve: to the Harts, the Kims, and the Stevensons, no less the peculiar families of my fishing companions and classics department colleagues, you all have my deepest gratitude and love.

\section{Notes}

1 My perception is that the opposition of intellectual/spiritual to body does not originate with Plato and only infest the West. Readers familiar with the Buddhist, Hindu, Manichaean, and Mazdaist traditions of late antiquity will be aware that the East also participated in this very human tendency. Orientalist instincts may often be at work here, as critiqued in, for instance, E. Slingerland, Mind and Body in Early China: Beyond Orientalism and the Myth of Holism (Oxford, 2019).

2 Bernard du Rosier, Ambaxiatorum brevilogus (1436), Ermolao Barbaro, De officio legati (ca. 1500), Etienne Dolet, De officio legati, and De immunitate legatorum (1541), and Conrad Braun, De legationibus (1548).

3 A. Becker, 2015, continues to refine the sociological conceptions surrounding Roman changes in diplomacy.

4 W. Stevenson, "Exiling Bishops: The Policy of Constantius II," Dumbarton Oaks Papers 68 (2014) 7-27. (C) 2014 Dumbarton Oaks Research Library and Collection, Trustees for Harvard University. Originally published in Dumbarton Oaks Papers 68, edited by Margaret Mullett. 


\section{Approaching Roman Christian diplomacy in context}

Twenty years before the Christian era, a group of "Ethiopian" diplomats were escorted by Roman soldiers to Octavian's winter palace on the Greek island of Samos. ${ }^{1}$ Only recently titled Augustus, ${ }^{2}$ he had begun officially receiving embassies as an individual. ${ }^{3}$ Though republican Romans asserted that the senate handled foreign policy, ${ }^{4}$ ambitious nobles had gradually paved the road to monarchical diplomacy by individually cultivating powerful non-Roman clients. Against his own propaganda of a restored republic, however, Augustus established early in his reign that all diplomacy would be focused on him as princeps, ${ }^{5}$ a precedent that would take root and grow through the 4th century into the celebrated practice of the Byzantine court. ${ }^{6}$ Augustus's legate Petronius had recently repulsed an attack by the famous Kandake (queen), Amirenas, ${ }^{7}$ driving his army through weak opposition all the way south to the cult center of Napata (modern Karima, Sudan, about 300 miles north of Khartoum and 700 miles west of Mecca). ${ }^{8}$ When the queen's ambassadors approached the general seeking peace, he insisted that they must proceed to Augustus. They pled ignorance of both Augustus and the route to find him, so Petronius sent a contingent of guides that appeared shortly thereafter on the Greek island of Samos with Amirenas's trusted legates. No doubt, the discussions were held in Greek, ${ }^{9}$ exotic place names beyond the fringe of the empire were investigated, and Augustus's court immediately equated the city of Swennet (modern Aswan), named for the goddess of childbirth, with the familiar goddesses Eileithuia (Greek) and Lucina (Roman), names that would soon be attached to the conquered city. ${ }^{10}$ After these ceremonious discussions, Augustus magnanimously dismissed the delegation to announce to the Kandake that the Roman emperor had relieved them of paying their tribute.

In these and similar events of the 20s BCE, Augustus deftly slipped into the ageold and archetypal role of potentate. Via his posthumously published biography, now called the Res Gestae, Augustus underscored his supreme geopolitical status by noting only reception of diplomatic gifts, never donation. ${ }^{11}$ And the land of the Kandake, rarely a stranger to diplomacy with potentates from pharaohs to Persian and Hellenistic kings, immediately fell into a comfortable, shallow détente with the distant emperor. This condensed tale must serve as our introduction to Roman diplomacy, a topic this book will explore throughout and summarize in earnest in Chapters 8 and 9. Foreign embassies would bring gifts, news, and requests to the 
emperor, and the emperor would send forth armies, royal assignments, and stories of conquest. Augustus did commission an exploratory party to South Arabia, but this became in the Res Gestae a conquering army bringing the furthest regions of the known world under his rule. ${ }^{12}$ In this Augustan form, diplomacy started from armies, from violence applied, and from military commanders' circumscribed discretion. Note well that neither the emperor nor the Nubians ("Ethiopians") nor the near-contemporary author (Strabo), throughout the episode, took any interest in differences of language, self-understanding, or religion. Three hundred years later at the end of the 3rd century, the emperor Diocletian would underscore unity with the same southern "barbarians" by repurposing the temple compound of Philae on an island in the Nile (now inundated about 60 miles south of the Aswan Dam), a grand testimony to common gods and culture. ${ }^{13}$

But within a century of Diocletian's gesture, the dramatic eruption of Christianity on both sides of Roman imperial boundaries would foster the first glimmerings of a grand shift from Augustus's to Justinian's diplomacy (6th century $\mathrm{CE}$ ), from potentates receiving generic emissaries to holy kings sending specific missionaries. This chapter will argue against a long-standing tradition still held by contemporary scholars that Constantine, upon his conversion and along with his ambitious Christian allies and successors, immediately set out to convert the world. Throughout the rest of the book, we will instead turn to two case studies that illustrate simultaneously how slowly, and ineffectively, Augustus's diplomatic precedent was altered and yet how boldly and originally our two innovators, the emperor Constantius II and the bishop of Constantinople John Chrysostom, experimented. But such a story requires a setting. This chapter will argue that the tale of innovations only makes sense when situated in a murky world of complex and uneven change, change from clear Roman geopolitical dominance to ambiguous coexistence, change from settled Roman views of self and subjects to new understandings of cultural difference, and change from traditional Roman practices of diplomacy (Constantine) to new Christian techniques (Constantius).

\section{Challenges to understanding: "religion"}

Perhaps the most impenetrable barrier to modern understanding of late Roman culture confronts us dauntingly in our profound feelings surrounding the concept of "religion," feelings ranging from abhorrence to fanaticism. We naturally project these emotions across the millennia, but how historically useful can this projection be? For hundreds of years, Western scholars have celebrated the wistfully noble "pagan" resistance to a destructive Christian intolerance, while learned Christians have championed the victory of their civilizing truths over polytheistic darkness. This dialectic, often masked, and usually far more nuanced, has both driven and benefitted the growth of late antique studies. But this book will try to venture onto a less traveled course, a quixotic journey to an ever-receding land always just beyond our cognition, a world meeting "religion" for the first time.

How can we approach the topic of "religion" in antiquity? It requires a vivid imagination for a modern Westerner to approach traditional Greco-Roman cult. 
What was the experience like drinking at a pre-party before attending a comic performance in Aristophanes's Athens? Many have had a few drinks before moving on to the comedy club, but the Athenians were performing a very different action. First, the whole state was involved. Elected state officials, archons, oversaw everything from funding of the chorus to selection of the best plays, to judging of those plays. All Athenians were invited, and a significant portion of the state's population might attend (20,000 could easily be 25 percent of citizens). ${ }^{14}$ This whole "religious" event, the city Dionysia, was thought to have originated when the city Eleutherae, having voted to leave the neighboring city-state of Boeotia and join Athens, sent their holy cult statue of the god Dionysus to Athens's capital. ${ }^{15}$ In fact, comic performances may have been a deliberate addition to the festival in the early 5th century as an expression of democratic leanings - that is, cheap entertainment for the common citizens through mockery of the powerful. And, of course, the Athenians "worshipped" Dionysus, the god of wine (and release from stress), with drinking, dancing, and laughing at pointed satire of the elected officials. This was the sort of state cult that makes it difficult to imagine walking past a friend on the way to the theater and hearing him say he was not attending because he is not very religious. In fact, when Euripides publicly summoned such a reluctant figure to the stage in $407 \mathrm{BCE}$, Pentheus in his masterpiece, the Bacchae, this Dionysus-dissident suffered the tragic flaw that most of us would connect with religious fanaticism. And he died violently for it. The drinking, acting, and laughing all supported the state and thus were expected from citizenship in the state while simultaneously forming the essence of the cultic expression to a divinity - one that would be anathema to modern welfare states with their strict mechanisms for suppressing drunkenness. This was not going to a bar or going to the theater or going to a rowdy public festival or going to a church/mosque/ synagogue or some combination of the above. Belonging to an ancient city-state required "religious" participation in state cults. With religion and state tightly melded, what were the prospects of ancient citizens even understanding the words "religious" and "secular"?

\section{Challenges to understanding: "secular"}

"Secular" is a Roman word (saecularis) whose modern meaning is expressed better by the ancient Latin profanus or Greek bebe $l o s$, "profane" - in the sense of "outside the circumscribed zone of sanctification." 16 But do these words mean "secular" in the sense of "removed from religion, not-religious, religion-free"? Was there a "secular space" in Greco-Roman antiquity? How much of a space is required to begin to distinguish religion from state? The trial of Socrates in 399, in which the street philosopher was convicted to death for corrupting the state's "religious" institutions (our modern language), at least according to Plato's and Xenophon's versions thereof, ${ }^{17}$ revealed no trace of an argument that the state lacked a right to judge a citizen's religious beliefs and accordingly to punish using its full judicial power. No doubt Athens, and a few other city-states, had philosophers on the fringe of society who espoused a rationalist agenda similar to some 
modern secularist views, ${ }^{18}$ but these remained on the sidelines of policy throughout antiquity. A rare and exhaustive insight is afforded through Cicero's dialogue De Natura Deorum, in which extraordinarily well-educated Roman aristocrats are depicted staking out philosophically sophisticated positions on something close to what our modern term "religion" suggests. But most of their utilitarian ratiocination, for instance, with respect to politics, assumes that the state requires religion in its current form - that is, as a state cult fronted by priests selected from the political elite. ${ }^{19}$ Readers who deny that this state cult had a presence in the people's day-today lives should consult a Roman calendar or the pages of imperial literature. ${ }^{20}$ The so-called Skeptical, or Academic Skeptical, school of philosophy represented by Gaius Cotta, in Cicero's dialogue, had its influence in the empire, especially in the late 2nd-century figure Sextus Empiricus. But this "school" never overtly taught that religion should be sequestered from public life and was eventually absorbed into Augustine's theology. ${ }^{21}$ Gaius Velleius's detached view of the gods in the dialogue may have been influential in the modern undermining of traditional theological positions, ${ }^{22}$ but nowhere does the character produce a hint at even understanding what "secular society" would be. In short, the philosophical discussions emanating from ancient salons and schools never affected society to the extent that any community would have understood the modern term "secular."

\section{Challenges to understanding: church and state}

So without a socially functional conception of the secular, how distinct could church and state become? The answer is, thanks to the advent of Christianity, surprisingly distinct. The origins of Roman interaction with Christianity established new political and social divisions. ${ }^{23}$ Augustus's autocratic political system, the "principate," feared secret meetings, as seen from the liberal, but telling, letter of Pliny as provincial governor to the emperor Trajan (112 CE) asking how to punish Christians for such meetings. ${ }^{24}$ From the Roman perspective, the fanaticism of this exclusive cult, in which devotees would face torture and death rather than recognize imperial divinity, automatically set it apart. Of course, as the fanatic sect spread, the opposition fitfully mounted until in the early 4th century, persecution of Christians in eastern cities had become manifestly counterproductive. ${ }^{25}$ When Constantine relaxed Roman suppression of Christianity, there was already a natural division. Devout Christians would be loyal to their bishops, and traditional Romans would resent this. What happened thereafter represents one of the most fascinating political and sociological events in history. The Christian church sprang out from the underground as an improbably parallel institution to the Roman state. Wherever a Roman official was collecting taxes or meting out justice, a Christian bishop was taking collections and overseeing courts. The awkward Christian imitation of Roman provincial units (still called "dioceses" today) went unchecked, and by the middle of the 4th century, we will see that bishops may well have outstripped provincial governors in political influence as well as resources, especially in intensely Christian areas like Egypt. In this book we will specifically investigate competition between the emperor Constantius and the bishop 
of Alexandria, Athanasius, in which two aspects of church-state relations should become clear: one, Constantius's court recognized the danger of losing political control of the empire to bishops, especially Athanasius; and two, the devout Christianity of the imperial court often contrasted and melded with the ruthless political tactics of Roman aristocrats-turned-bishops to such an extent that lines were often blurred. ${ }^{26}$ So while there was no discussion of a secular space in ancient society, there was certainly a distinction between church and state; this distinction between the emperor's court and powerful bishops finds no parallel in modern experience. It may be naïve to try to banish the influence of Voltaire, or even Khomeini, from our consciousness. But the effort will be made to repress the "war on Christmas" and conjure something more like state law enforcement against mafia in Sicily.

As for "state," the Roman polity of the 4th century presents itself as a curious specimen. On the scale of modern statehood, between Switzerland and South Sudan, ${ }^{27}$ where would we place the Roman state that Constantine inherited? Starting from basic modern criteria for fragile statehood - that is, ethnic and religious division, widespread corruption and inequality of wealth, and factionalism of elites, we would have to consider Diocletian's Rome on the South Sudan-end of the spectrum: frequent religious conflicts, border wars with hostile ethnic groups, disastrous taxation efforts, an oppressed tenant farmer class, and violent rebellion by almost every member of the elite who gained an army. Between 306 and 324, the emperor Constantine did almost nothing but battle incursion and insurgence including bloody conflict in the streets required to retake the capital city (312) and a long campaign against a brother-in-law, Licinius, who had stolen the eastern empire (ca. 316-324). Meanwhile, Christian strife was widespread, ranging from the Donatist factionalism to the Arian schism. The enormously influential courtier Eusebius of Caesarea's accounts of rule in the East, however tendentious, paint a picture of cruel and open oppression under the Eastern rulers Galerius and Maximinus II, both of whom strove to topple Constantine. The emperor Galerius, who grew up in Dacia, was even said to have initiated his brutal head tax as a punishment for Trajan's tribute inflicted centuries earlier on the newly conquered Dacians. ${ }^{28}$ Chapters 3 and 4 of this book will tell a small part of the story of state building under Constantine's son Constantius - a remarkable tale, given the chaotic forces whose impetus Constantine reversed but whose significant residue was inherited by his sons. Suffice it to say here that basic cohesion or unification, no less functional bureaucratic and juridical structures, essential to our conception of a state were sorely lacking in 4th-century Rome.

As for church, the diversity and vigor of Christianity in the early-4th century suddenly came into display when Constantine's court (preceded by Licinius's) ended persecution. In fact, months after the Edict of Milan was published, Constantine confronted the leaders of a bloody conflict between "catholics" and Donatists who arrived in Rome to seek his justice, ${ }^{29}$ and shortly after that meeting (concilium), the Council of Arles (314) would condemn Donatus and perpetuate centuries of conflict in African Christianity. That conflict concerned the condemnation of perceived traitors to the faith during the persecutions of Diocletian, but theological conflicts in the East concerning the nature of Jesus's divinity spilled over from the 
Council of Nicaea (325), a meeting designed to contain them. The power of bishops became apparent as they raised impressive funds; sat in judgment in their courts; ${ }^{30}$ and, most importantly, connived with each other to create factions, eject enemy bishops, and manipulate the imperial court. While the creative chaos of the 4th century would give final shape to the canonical Christian scriptures, generate many of the fundamental formulations of Christian theology, codify an impressive body of canon law, and drive the basic shape of ecclesiology for the next millennium, the "church" did not remotely achieve institutional stability. As the rest of this book will make obvious, modern or early-modern conceptions of an organized, expansionist, unified national church must be scrapped when visiting the 4th century. This riotous gathering of bishops, rich widows, monks, visionaries, ardent believers, and calculated converts presented an ever-moving target to all ancient imperial designs for unification, or modern scholarly hopes for generalization.

\section{Challenges to understanding: Constantine as symbol of Christian imperialism}

As heroic and successful as Constantine was in reversing the forces of political dissolution, we need to keep this success in context. In fact, because the demonstration of Constantius's innovation over his father is central to this book, it will be necessary to briefly demonstrate that Constantine, in the midst of his endless struggles as well as his creation of a new capital, did not harness Christianity to any significant diplomatic activity. This claim, in turn, runs into age-old and grand traditions of glorifying and vilifying Constantine for his ardent Christianity, an irrepressible piety that supposedly burst forth in a fireball of Christian triumphalism both within and without the empire. ${ }^{31} \mathrm{We}$ cannot take on a critique of the whole liberal tradition from Gibbon through the Whigs to our contemporary rationalizers, but a terse and pointed inspection of particulars may help to frame Constantius's innovation.

Timothy Barnes's provocative arguments that Constantine intended to Christianize Gothia and Persia will serve our purpose well..$^{32}$ This project was followed and set in a broader frame by the fascinating work of Garth Fowden. ${ }^{33}$ And both were revived recently by Elizabeth Fowden's focused piece on Constantine and easterners. ${ }^{34}$ These studies attempted to hammer down in detail the origins of how Christianity altered Roman imperialism, and Garth Fowden's in particular set this new style of imperialism in the context of the transformation of Rome's eastern neighbors in late antiquity. While it will be obvious that this book was partly inspired by the brilliant work of these scholars, it will be necessary to argue against some of their details and chronology.

The scattered evidence that Constantine sent imperial Christian missions, or even planned them, is ambiguous at best and, even when massed together and carefully interpreted, only illustrates the first Roman Christian emperor stumbling on modest and opportune missionary propaganda. We will focus on two serious and detailed arguments in favor of it: first, that Constantine was involved in the Christianization brought about by Wulfila among the Goths; and second, that 
Constantine had a plan to Christianize the Sasanian Empire. For each putative mission, court rhetoric and its later emanations via ecclesiastical historians present a possibility, but in each case, a close reading of our sources illuminates a lack of imperial policy. In reviewing these, we will see that the case for Constantine as the first missionary emperor is weak.

\section{The case for Constantine's mission to the Goths}

We start with the Goths whose Christianization Barnes asserts was at least claimed by Constantine. It is clear that Gothic evangelization began in the 3rd century, and Chapter 5 will argue that, after Constantius II and Valens took some interest, John Chrysostom was the first Roman official to actively foment it. But due to contradictions in our sources, it is possible to push some missionary activity back in time to the very end of Constantine's reign and tangentially connect it to his imperial program. The assertion has been made that Constantine had a hand in the ordination of Wulfila, the first bishop of the Gothic peoples. This assertion is built on a technical, chronological argument that has not been widely discussed. ${ }^{35}$

The most sympathetic sources for the life and work of Wulfila come from openly Arian authors, Auxentius and Philostorgius. ${ }^{36}$ These two authors' accounts are harmonized to give us the standard life: ${ }^{37}$ Wulfila was the grandson of a Cappadocian who was captured and taken as a slave in the Gothic raids of the 250s; from this, he is presumed to have been Greco-Roman on his maternal side, which might explain his fluency in Greek and Latin, and Gothic on his father's side, leaving him with his name "little wolf" in Gothic. He was born around 310 in Balkan Gothia to a family of sufficient influence that it was able to send him to Constantinople to be ordained bishop of all the Goths either at the end of Constantine's reign or at the beginning of Constantius II's sole reign in Constantinople (337). He returned to shepherd those living in Balkan Gothia for seven years until he was driven out by the first Gothic persecution of Christians in the late 340s. After this, he guided his flock into the Roman province of Moesia for 33 years, during which time he wrote a good deal and apparently produced the Gothic translation of the Bible and his Gothic grammar, both partially extant today. ${ }^{38} \mathrm{He}$ was present at the Council of Constantinople of 360 at which he signed the Homoian creed of Eudoxius and may have been involved in the negotiations the Goths held with the Arian emperor Valens in the mid-370s, before the battle of Adrianople. Philostorgius diverges from Auxentius by stating that the young Wulfila was sent with an embassy to meet with Constantine. Barnes builds upon the latter to suggest that the meeting with Constantine may have coincided with Constantine's tricennalia in 336, and thus, Wulfila may have been ordained bishop to be paraded, in Roman triumphant style, as a new Christian version of Roman imperialist propaganda. ${ }^{39}$

The heart of the Arian version has the merit of being based on Wulfila's student Auxentius's direct personal knowledge, and we can presume that, as Arian, it is at the least a sympathetic narrative. But the striving for biblical overtones undercuts confidence in these accounts' historical veracity. In these sources Wulfila appears as a combination of Jesus, David, and Moses, starting his ministry at 30 years old like 
Jesus, serving seven years in his kingdom and 33 years out like David, and as the Gothic Moses leading his people to freedom across the wilderness. ${ }^{40}$ Philostorgius's less intimate relation to Wulfila and more tendentious approach can only add to skepticism with his account. In fact, the only clear merit of privileging Philostorgius's chronology is to show Constantine's imperialistic/missionary zeal. Barnes seems to be pushing the sources as far as possible in this direction, and his argument is thus left hanging. Certainly, if we privilege one unique detail in Philostorgius's account, which had many opportunities for corruption and interpolation between the author's composition and the transmission in Photius, and we explain away the numerous accounts opposed to this, and we push the chronology to its furthest possible extent, we can establish the possibility that Wulfila was ordained under Constantine. But the context of Constantius's more extensive interest in missions makes it that much more likely that Wulfila's imperial support began under him, if there ever was such support. Why Auxentius, student and friend of Wulfila, would deliberately falsify the ordination of his mentor is not clear, perhaps to set his glory in the time of the more Arian-friendly Constantius? But it seems less likely that all the orthodox authors would agree with their Arian brethren and that we would wind up with only one voice promoting a Constantinian ordination. Even if Wulfila were ordained under Constantine and were paraded in the tricennalia, this would hardly be evidence in itself that he had a profound interest in, or strategy to, Christianize Gothia.

Barnes cites more evidence for Constantine's interest in Gothia elsewhere, claiming that Constantine intended, or at least wanted to appear intent, to Christianize Gothia:

When Constantine concluded a treaty with the Goths in 332 . . he insisted on including religious stipulations, which enabled him (and his panegyrist Eusebius) to claim that he had converted the northern barbarians. ${ }^{41}$

He bases this contention on three sources, which deserve some scrutiny. Barnes's first piece of evidence is drawn from Athanasius's Apology against the Arians (86). In this section Athanasius, whose relations with Constantius in the mid-350s as bishop of Alexandria, as we will see in Chapter 3, were greatly strained, is quoting a letter from Constantine to the eastern bishops chiding their contentiousness:

For indeed through my devotion to God, peace is preserved everywhere, and the Name of God is truly worshipped even by the barbarians, who have hitherto been ignorant of the truth. And it is manifest, that he who is ignorant of the truth, does not know God either. Nevertheless, as I said before, even the barbarians have now come to the knowledge of God, by means of me, His true servants, and have learned to fear Him Whom they perceive from actual facts to be my shield and protector everywhere. And from this chiefly they have come to know God, Whom they fear through the dread which they have of me. But we, who are supposed to set forth (for I will not say to guard) the holy mysteries of His Goodness, we, I say, engage in nothing but what tends to dissension and hatred, and, in short, whatever contributes to the destruction of mankind. ${ }^{42}$ 
If we can trust Athanasius to have quoted accurately, and we have little reason to doubt him, this statement comes close to Barnes's contention that Constantine was claiming to have Christianized barbarians. The letter manifestly shows Constantine taking credit for barbarian Christianity. But the context of this letter should not be lost. Of all places to make the claim that one has Christianized, and intends to continue Christianizing, external people by the sword, a letter sent to quell the squabbles of eastern ecclesiastics seems an unlikely place. Even if Constantine were already contemplating a crusade against the Sasanids (to be discussed below), an announcement of intention to Christianize beyond the borders of the empire would call for more than a side comment in a letter. It seems more likely that Constantine merely made this comment in passing to shame the bishops: how could they continue to fight when even the barbarian hordes have settled down in Christian peace? The lack of detail also undermines any sense that Constantine was claiming a successful policy of Christianizing the barbarians.

The second testimony comes from Eusebius's Life of Constantine (4.5) and requires full quotation. Here, at the end of the work, Eusebius praises Constantine's purported pacification of the northern barbarians:

What need is there for me to mention even incidentally how he subjected barbarian races to Roman rule, how he was the first to subjugate the Gothic and Sarmatian tribes which had never before learnt to serve, compelling them to accept the Romans as their masters even against their will? Previous rulers had even paid tribute to the Goths, and Romans served barbarians with yearly payments. Such a reckoning was not acceptable to the Emperor, nor did it seem good enough to the Victor to make the same payments as his predecessors. Confident in his Saviour and brandishing the victorious trophy over them too, he very soon subdued them all, sometimes taming the refractory with the military arm, sometimes pacifying the rest by reasonable negotiations, converting them from a lawless animal existence to one of reason and law. In this way the Goths learnt at last to serve Rome. As to the Sarmatians, it was God himself who thrust them under the feet of Constantine, defeating men who gloried in their barbaric mentality in the following way. When the Goths attacked them, the masters armed their servants to repel their enemies. But when the slaves had won, they turned their arms against their masters and drove them all from their own land. The masters found no other safe refuge than Constantine alone. He knew the meaning of rescue, and received them all as subjects in Roman territory. Those who were suitable he enrolled in his own forces; to the rest he apportioned land for cultivation of the means of subsistence, so that they acknowledged that the disaster had turned out good for them in that they enjoyed Roman liberty instead of barbaric bestiality. Thus God bestowed upon him victories over all the nations, so that of their own accord all sorts of barbarian tribes were willing to submit to him. ${ }^{43}$

It is not clear how this passage demonstrates that Constantine and Eusebius were claiming that they Christianized the barbarians. Eusebius stresses a military and 
political pacification of the Goths and only adds that God's hand was clear in the similar pacification of the Sarmatians. Emphasis at the end is placed on civilization and not Christianization. In fact, the passage presents an excellent opportunity for Eusebius to praise Constantine's external missions, but Eusebius not only does not include such a statement in the passage above but continues the narrative by discussing the outrageous appearance of the barbarians when they arrived in Constantinople to pay tribute (4.7) ${ }^{44}$ Rather than underlining Constantine's intention to Christianize external peoples, this section of the Life of Constantine underscores Constantine's (and Eusebius's) remarkable lack of interest in external missions. Beyond reference to the Christian God's hand in domesticating the Sarmatians, the whole passage reads like any traditional triumphal account of barbarian tribes brought under the Roman yoke.

Further reason to doubt Eusebius's (and Constantine's) missionary intentions can be drawn from two other genres. It is well known that Eusebius is the father of ecclesiastical history but less well recognized that his own historical writing all but ignores missionaries outside the empire. ${ }^{45}$ If Constantine were so intent on Christianizing the northern barbarians, it is strange that Eusebius ignored the topic in his own history. Furthermore, we would expect that an emperor and his supporters would want to extoll successful policies like Christianizing foreigners in their propaganda. But the panegyrics to Constantine fail to include any mention of Christianizing foreigners. The burden of proof seems to be on those like Barnes who suggest that Constantine wanted to Christianize barbarians. The very lack of intentional discussion of the topic in Eusebius argues that neither the author nor his ruler considered external Christianization important.

Barnes's last piece of evidence appears in the ecclesiastical history traditionally attributed to Gelasius of Cyzicus. ${ }^{46}$ In this section, the historian, writing in the late-5th or early-6th century, is discussing how the Iberians (ancient people living in Caucasus) were converted, in which he closely follows his predecessors Rufinus, ${ }^{47}$ Socrates ${ }^{48}$ Sozomen, ${ }^{49}$ and Theodoret ${ }^{50}$ in describing how a captured Roman slave woman performed miracles among the Iberians and convinced them to convert, after which they sent to Constantine for priests (or a bishop). The historian then adds a few details at the end of his account of the conversion of the Iberians (people in the Caucasus): ${ }^{51}$

The reverent and Christ-loving emperor Constantine received their delegation kindly and he rejoiced when he received their request. He ordered the bishop of Constantinople, Alexander, to appoint a bishop for the Iberians, at the same time comprehending that it was the will of God to subject the foreign tribes to him. ${ }^{52}$

In this section, our historian was following Rufinus's Ecclesiastical History - these are the only two accounts to mention their source, a certain Bacurius who was acquainted with Rufinus in Palestine. ${ }^{53}$ Since the sentiment expressed in Rufinus, that Constantine was happier with the conversion of this unknown people than he would have been by conquering them, stands out as typical of the apologetics 
practiced by church historians, there is little reason to presume that the anonymous historian did anything more than echo Rufinus. Such testimony can hardly demonstrate that Constantine intended to Christianize northern barbarians.

\section{Constantine's plan to Christianize Persia}

Barnes, and the Fowdens following Barnes, extend this argument to suggest that Constantine's planned expedition to Iran was part of a strategy to Christianize the peoples under Sasanian rule. ${ }^{54}$ After building a convincing case that Constantine was concerned for the Christian subjects of Shapur, and that he was planning an attack on Sasanian territory, Barnes extends himself to this:

Constantine proposed to conduct his Persian expedition as a religious crusade. Bishops were to accompany the army, a Christian version of the Old Testament tabernacle was prepared to accompany him, and he proclaimed his intention to be baptized in the River Jordan before he invaded Mesopotamia. ${ }^{55}$

The only source for this assertion is Eusebius's Life of Constantine, which makes no mention of crusade or a goal of conquering Persian lands in the name of Christ. ${ }^{56}$ Most of even Eusebius's account could apply to the traditional Roman habit of mounting a Persian expedition. If almost every significant emperor from Trajan to Julian attempted such an expedition, why should we see Constantine's as unique in motivation? It seems obvious that a Christian emperor would bring along Christian devotional trappings. Why do these imply a crusade? It is more likely that Constantine had achieved enough control of the traditional empire that, as had his predecessors, he sought out new methods of bolstering his reputation.

\section{Other historiographical challenges}

The scarcity of source materials manifest in discussing Constantine's career above calls for some introspection. Do we really have enough historical information to discuss topics like missions outside the empire and diplomacy? Do we even have enough to discuss relations with the world east of the Roman Empire? For those interested in Roman military campaigns or early relations with the Parthians/ Persians, authors like Tacitus and Ammianus Marcellinus provide a relatively bountiful and trustworthy narrative. What do we know about imperial relations with far-flung regions of the world? What we do learn from scattered sources often provides its own aura of caution. For instance, Pliny the Elder's Natural History, a goldmine of scattered and arcane information, offers us this story. When Annius Plocamus was collecting taxes on the Red Sea, one of his freedmen got caught in a storm off the east coast of Arabia and was swept to Sri Lanka. ${ }^{57}$ This freedman spent six months there, achieved fluency in their language, and ended up conversing with the king about Rome. When the king tested various Roman denarii and discovered that they all had uniform amounts of gold, he decided that he should become acquainted with these unusually just people. So he sent to the 
emperor Claudius an embassy from whom the Roman court learned a good deal about the culture, economy, and geography of Sri Lanka. Judging by Augustus's record alone, we have every reason to believe that these sort of embassies were frequent and that the wealth of information shared was not systematically recorded and archived. How did Pliny learn of this story? ${ }^{58}$ As tempting as it may be to imagine that Claudius's court kept an archive of such information from which curious scholars like Pliny could draw, it is unlikely. ${ }^{59}$ Most likely, Pliny was living in Rome at the time and received the story orally. ${ }^{60}$ As for an account shared by Annius's freedman, we can be certain this in itself would have been ignored. Strabo, writing in his Geography shortly before the story quoted at the beginning of this chapter, candidly states:

As for the merchants who now sail from Egypt by the Nile and the Arabian Gulf as far as India, only a small number have sailed as far as the Ganges; and even these are merely private citizens and of no use as regards the history of the places they have seen. ${ }^{61}$

We will see in the next chapter that these merchants not only served as the undoubted source of the most reliable information on the nautical world to Rome's east but also as the agents of exchange, eventually becoming informal ambassadors for Christianity. To know that major authors like Strabo, and most likely Pliny the Elder, openly and categorically rejected merchants' testimony due mainly to class bias opens up to us the complexity and depth of our source challenges. An unlikely concatenation of events brought Pliny's report to us: storm-tossed freedman survived, he made significant contact with foreign king, embassy arrived at Roman court, someone remembered the embassy's report and shared it orally, Pliny retained this information and chose to include it, and the text of Pliny survived. If our ancient authors were ignoring the best source material - that is, merchant stories - and if we needed a near miracle to luck into the wisdom of the Sri Lankan king's embassy, and of course, if we can sift out the misinformation sneaking into the transmission from ambassadors to courtiers through Pliny's cognition and writing (and textual problems) to us, then we are not surprised that the ancient extant record should not be considered more than a random sampling of stories about diplomacy and foreign peoples. ${ }^{62}$

No doubt, caution is due. But on the bright side, as long as modern critics proceed cautiously with our spotty record, there are reasons for guarded confidence. One example can be drawn from Pliny's same story, what might be called an unguarded aside. Pliny states, as though a commonplace, that Annius Plocamus had won the franchise to tax the Red Sea region and that he was taxing all along the Arabian coast. This exposes to us the frustrating question: what were the understood boundaries of empire? Most maps draw the line of empire roughly along the eastern boundaries of what are now the modern nations of Jordan and Syria. While more than a few will grant Augustus his boast and draw the province of Egypt extending not only down the Nile to Aswan but drawing a line east across to the Red Sea, thus including the important port of Berenike, ${ }^{63}$ none draw a provincial 
line that would include the Arabian Red Sea coast; add on that Annius's freedman must have been taxing along the coast of modern Oman and Yemen on the Gulf of Aden or the Arabian Sea in order to plausibly be blown east to Sri Lanka. Who would have known that Roman tax agents were granted such franchises? Who would have thought that Roman freedmen were sailing the Arabian Sea in the 40s shaking down local ports and merchants? And yet the very unguardedness of Pliny's comment lends it more credence. ${ }^{64}$ Such tidbits of information open up whole new areas of investigation in Roman eastern policy. Finally, and perhaps most importantly, we rely on the industriousness of modern scholars to have gathered all these pertinent details from highly scattered literary remains and on modern archaeologists to have excavated, interpreted, and collated the far more plentiful physical remains. Synthesizing the smattering of literary clues with the robust archaeological record should bolster enough faith to confront the formidable challenges inherent in reconstructing Roman diplomacy.

On the topic of methodological challenges, anachronism, in all its layers and manifestations, demands attention. We have already passed quickly over the problem of projecting our strong modern feelings regarding "religion" and "church and state" onto the 4th-century context. Lovers of history will always have to negotiate their dilemma that the very passion driving interest in past events can distort clear understanding of those events. Other facets can quickly be added. For instance, all our 5 th-century ecclesiastical historians naturally imagine the well-formed institutions of their own time as already in place in the inchoate 4th century. In Chapter 4 we will review assumptions that the familiar and well-defined roles fitted to ranks like agens in rebus or notarius (high-level messengers and functionaries of the imperial court) under Theodosius II are assumed to be operative in the free-form nascent bureaucracy of Constantius. On the other hand, while antennae are kept tuned to anachronism, a fanatical anti-anachronistic stance cannot be fruitful. We understand the past by building bridges from our own current experience across the many accrued layers of storytelling and mythmaking back to an often scantily documented object. For this reason, analogies and metaphors from the present will be used in apparent contradiction to cautions against anachronizing.

Finally, this book's method will be to borrow a convention of crime fiction and so to build a strong circumstantial case for our early missions. On the one hand, all the little clues above, when organized carefully into a clear narrative, can add up to a convincing case. On the other hand, abundant clear evidence and pure certainty come along rarely. Little in ancient history can be proven beyond a doubt, and many well-accepted accounts have been overturned. For instance, to turn to a famous example, in 1900, it was accepted fact, and an important part of aesthetic approval, that ancient Greek sculpture and monumental architecture was designed to be unpainted. So powerful had been the aesthetic pleasure of gazing upon weathered monochrome ruins - and this aesthetic had been so deeply instantiated in modern monumental buildings from Rome to Washington - that it took decades for the countervailing evidence to sink in that all ancient sculpture and buildings were painted. Millennia of sunshine and rain wore the paint off. Assuming that ancient buildings were stark and white was a reasonable certainty whose 
many layers of "narrative" in modern experience spoke convincingly to us from the east facade of the Louvre (1670) through the U.S. Supreme Court Building's facade (1935) to the present. Now the enormous aesthetic and cultural authority of an unpainted neoclassical building still leaves many of us resisting the fact that the Parthenon was painted brightly. Undoing a lifetime of visual instruction requires a great effort, but at the same time, our interest in, and affection for, the Parthenon's symmetrical columns was born from both observable facts and the "narrative" of modern buildings. The layered narratives surrounding late Rome and early Christianity are no less powerful and omnipresent in our consciousness, so they will require a similar effort for us to begin revising.

\section{Plan of the book}

Girded with cautions against treacherous source material and nagging anachronisms, we lurch forth to discover a strange diplomatic land between Augustus's supercilious reception of embassies (1st century) and Justinian's aggressive Christian outreach (6th century). The quest requires gathering as many scattered sources as possible and then organizing them in a narrative that will often extend into speculation. Most critical throughout the project is building a gradual context up from the known to the unknown. We will start with a smattering of evidence surrounding Constantius's mission to the peoples on the far end of the Red Sea, which, once carefully organized in a chronology, gains credence by its coherence and its ability to explain details previously underutilized or disconnected from this narrative. The context is then expanded to Constantius's overall career, with particular interest paid to his management of bishops, most of which ended up focused on Athanasius whose relations in Aksum bring us full circle. With this remarkable mission initiated by the imperial court (or state) described, we move on to the first organized external missions initiated by Greco-Roman clergy. Enough clues remain of John Chrysostom's program to structure Gothic Christianity that a responsible reconstruction can be pieced together. Though less is known on his efforts directed toward Christians living under Sasanian (Persian) rule, an extension based on analogy with the Goths reveals tantalizing speculation both about John's motives and the general context of Christianization that made the religion susceptible to diplomatic exploitation. Perhaps most speculative will be the effort to put these two innovators in perspective within the development of the mature Byzantine "commonwealth" of Christian kingdoms/states. ${ }^{65}$ No doubt, such speculation will naturally elicit criticism. It can only be hoped that the process of opening a new area of investigation on the origins of Roman Christian diplomacy will initiate a fruitful discussion.

\section{Notes}

1 Strabo, Geography 17.1.54, who calls the people of Meroe Ethiopians, who might more accurately be called Nubians. Cracco Ruggini, 1974, explores the line between history and romance in this story. 
2 Res Gestae 34.

3 Badian, 1958, p. 262: "The Empire was based on the personal loyalty of leading men throughout the provinces to leading families at Rome, and this attachment proved to be independent of political vicissitudes and ... on the whole unaffected even by the fortunes of those families. It was the foundation on which the emperors were to build."

4 Polybius, Hist. 6.13, or, for instance, Sherwin-White, 1986.

5 Benoist, 2012, expounds on the language of Augustus's diplomatic shift.

6 Millar, 1982 and Luttwak, 2009. Gagé, 1959, pp. 227-228, reminds us of the perhaps more telling precedents of Marc Antony in Alexandria, including the public beheading of the Judaean king Antigonus and the triumphal parading of Artavasde, king of Armenia, in gold chains.

7 Török, 1997, pp. 448-467.

8 Strabo, Geography 17.820.

9 Strabo, Geography 15.719, quotes Nicolaus of Damascus who met three ambassadors in Antioch on their way from the Indian king Porus to Augustus. They had a letter handwritten in Greek on vellum by the king himself. The rulers of India from the time of Ashoka had proven their familiarity with the language of the neighboring Hellenistic kingdoms.

10 Beaumont, 1871, p. 260, for example: the city's name could derive from language of trade also and was famous in antiquity for its quarries. It was known as Syene throughout the period of interest in this book.

11 Res Gestae 26-33, summarizes the "foreign policy" of Augustus. All credit for subjection of new kingdoms as well as all glory for reception of emissaries is focused manifestly on Augustus ("me" in the first person in the document).

12 Res Gestae 26, where a fabulous claim of conquering all the way to the border of Himyar (modern Yemen) is floated. Strabo's account is discussed in Chapter 2.

13 Procopius, Wars 1.19. Nautin, 1967.

14 Henderson, 1991, illuminates the role of women as spectators at Athenian drama.

15 Rhodes, 2003, p. 111. In spite of his article's title, Rhodes is merely trying to correct perceived overemphasis regarding democracy's intimate relation to Attic drama.

16 Thuc. 4.97, for instance, where the Boeotians charge that the Athenians performed

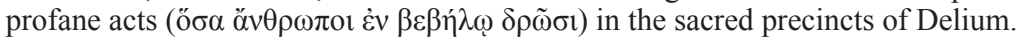

17 Plato, Apology, and Xenophon, Apology and Memorabilia.

18 Protagoras of Abdera and Theodore of Cyrene (the "atheist," not the mathematician) jump to mind, both of whom generated many mythical stories and no secularizing policy.

19 Cotta, for instance, at De Natura Deorum 3.5-6, after spending all of book one criticizing the intellectual foundations of theology, vehemently defends his priesthood, the Roman state cult, and the traditions behind them. That is, traditional ritual, auspices, and prophetic warnings are conventions beyond philosophical questioning.

20 Responsible estimates have over 100 festival days per year with theatrical events from the time of Nero through to Constantius, DuPont, 1985, p. 63.

21 Augustine, Contra Academicos.

22 For instance, Fosl, 1994.

23 Rives, 2009, illuminates how Jews, both within and without the empire, held diplomatic relations with the emperor and how the Christians appear to have followed this precedent. Beyond these two religions, and the semi-religious cult of athletes, only cities were in the habit of sending embassies to the emperor. Such a practice in the 2 nd and 3rd century would also contribute to the division of "church" and state.

24 Pliny, Ep. 10.96. A similar fear is still present in the late-2nd century when Millar, 1982, p. 15, reminds us that Commodus's treaty with the Marcomanni stipulated no more than one public meeting a month and that with a centurion always present.

25 Both Eusebius and Lactantius celebrate the accommodation forced on Galerius in the eastern empire in 311 , most likely caused by resignation that torturing and killing Christians had become countereffective. 
26 Milner, 2015, details a fascinating story of the placement of Constantius II's statue in place of an athlete-hero in a provincial city whose setting illuminates Christians' newfound comfort participating in emperor cults. Salzman, 2000, summarizes the mentalité of Western aristocrat-bishops.

27 South Sudan edged out Somalia in the Fragile States Index for 2018.

28 Lactantius, De Mortibus Persecutorum 23, paints a vivid scene of suffering in the eastern empire under Galerius.

29 Girardet, 1989.

30 Humfress, 2011, provides a judicious view of the hazy world of bishops and their legal courts (episcopalis audientia). But there are many other interesting perspectives - for example, Slootjes, 2004, Kauffman, 2003, and Lenski, 2001.

31 Eusebius of Caesarea is often seen as the source of Christian triumphalism, for instance, in Trompf, 2000, p. 213, discussing Sokrates, Sozomen, and Theodoret: "Those extollers of the pro-Nicene Christian 'establishment,' that intellectual triumvirate who confirmed for all time the role of Church history as a necessary act of rhetoric and a distinct literary genre, followed their most notable predecessors, Eusebius of Caesarea, Rufinus of Aquileia and Philostorgius of Cappadocia, in documenting the apportionments of divine justice in ecclesiastical and wider affairs. From Eusebius . . . they imbibed confident providentialism, if not triumphalism, reassuring their readers that God was protecting His people against error and political disorder."

32 Barnes, 1986, 1990.

33 Fowden, 1993.

34 Fowden, 2001.

35 Barnes, 1990, p. 544: "It may be suggested that he associated the consecration of Wulfila with the celebration of his tricennalia in order to give the traditional clichés of Roman imperialism a specifically Christian colouring." Against this position, see Kulikowski, 2005 , p. 361.

36 Heather, 1992, builds the most detailed narrative of early Gothic history, though Gothic religion gets little attention.

37 Gryson, 1980, pp. 244-251, for Auxentius, and for Philostorgius, Winkelmann, 1981. For more early biography, see also Sivan, 1996.

38 See PL18 or Streitberg, 2000. For an exciting epigraphic discovery, see Harmatta, 1997.

39 Barnes, 1990, p. 545: "It may be suggested that he associated the consecration of Wulfila with the celebration of his tricennalia in order to give the traditional clichés of Roman imperialism a specifically Christian colouring."

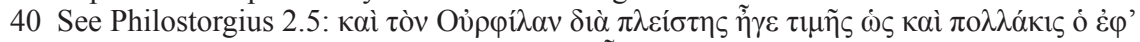

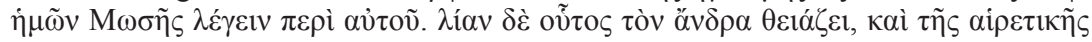

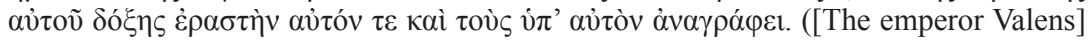
held Urphilas himself in such high honor, that he would often speak of him in conversation as the Moses of his day. [Photius's comment:] Philostorgius obviously defines the man as one sharing in his heresy.) See Auxentius 307r, Gryson, 1980, p. 246: vir beatus Wulfila cum grandi populo confessorum de varbarico pulsus in solo Romanie athuc beate memorie Constantio principe honorifice est susceptus. ut sicuti Deus per Moysem de potentia et violentia Faraonis et Egyptioum populum suum liberavit et per mare transire fecit et sibi servire providit, ita et per sepe dictum Deus confessores sancti Fili sui unigieniti de varbarico liberavit et per Danubium transire fecit et in montibus secundum sanctorum imitationem sibi servire dedit.

41 Barnes, 1986, p. 131.

42 Translation from Robertson, 1892.

43 Translation from Cameron and Hall, 1999, p. 155.

44 Eusebius, Vita Constantini 4.7.

45 Brock, 1995, p. 26, "Eusèbe passe presque totalement sous silence l'histoire de l'Église située à l'est de l'Empire romain." See also Stevenson, 2003, for a discussion of ecclesiastical historians' reticence to discuss external missions. 
46 The latest edition, Hansen, 2002, persuasively argues that the author was not Gelasius of Cyzicus and that this anonymous author wrote around 480 .

47 Rufinus HE, 1.10.

48 Socrates HE, 1.20, Hansen, 1995.

49 Sozomen HE 2.7.

50 Theodoret HE 74-76.

51 Barnes quotes 3.10.10, but in Hansen's edition, his point is illustrated at 3.10.20-21.

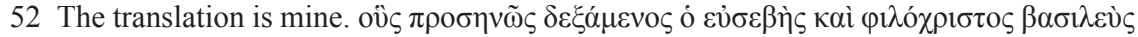

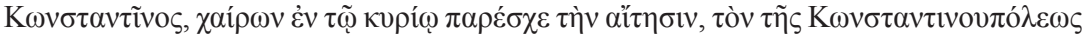

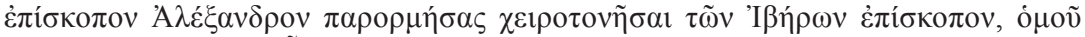

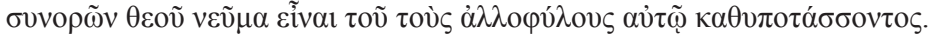

53 Rufinus HE 1.10: "Quibus (Iberian ambassadors) illo (Constantine) cum omni gaudio et honore transmissis, multo amplius ex hoc laetatus est, quam si incognitas Romano imperio gentes et regna ignota iunxisset. haec nobis ita gesta, fidelissimus vir Bacurius . . . exposuit." Theophanes Confessor (24), following our anonymous historian or the Greek translation of Rufinus, also reports the story with Bacurius as source. For a thorough study of Rufinus, Thélamon, 1981. For more detail on Bacurius, Haas, 2008, p. 108.

54 Barnes, 1986, pp. 126-136, and 1990, pp. 541-545; Fowden, 1993, 2001, pp. 377-398, that revives and strengthens some of the former's claims.

55 Barnes, 1986, p. 130.

56 Eusebius, Life of Constantine 4.56 and 4.62.

57 Weerakkody, 1997, provides a good survey of source materials on ancient Sri Lanka.

58 Dihle, 1964, is the classic source for caution on this topic.

59 Millar, 1982.

60 Meredith, 1953, p. 39.

61 Strabo Geography 15.4.

62 In the next chapter the Periplus Maris Erythraei, the best early source for the world east of the Roman Empire will be discussed. The text appears to be based on the experience of merchants.

63 Cottier, 2010, pp. 142-143.

64 De Laet, 1949, pp. 306-311, explains Annius's franchise by comparing severe import duties of 25 percent exacted along the Syrian border also, perhaps as an expression of Augustus's and Tiberius's repugnance for eastern luxury goods - for example, Tacitus Annals 3.52-54.

65 Obolensky, 1971, is the classic formulation. Kaldellis, 2017, p. 278, questions its historical foundation. Contemporary examination of 19th- and 20th-century historiography underscores the complexity - for example, Ignjatovic, 2016.

\section{Bibliography}

Badian, E., Foreign Clientelae (264-70 B.C.) (Oxford, 1958).

Barnes, T.D., "Constantine and the Christians of Persia," Journal of Roman Studies 75 (1986) 126-136.

Barnes, T.D., "The Consecration of Wulfila,” Journal of Theological Studies 41 (1990) 541-545.

Beaumont, W., To Sinai and Syene and Back in 1860 and 1861 (London, 1871).

Benoist, S., "Les membres de la domus Augusti et la diplomatie impériale. À propos de l'empire et des 'autres'," in A. Becker and N. Drocourt (eds.), Ambassadeurs et ambassades au coeur des relations diplomatiques (Metz, 2012) pp. 65-82.

Brock, S., "L'église de l'Orient dans l'empire sassanide jusqu'au VI siècle et son absence aux conciles de l'Empire romain," Istina 40 (1995) 25-43. 
Cameron, A. and S.G. Hall, Eusebius: Life of Constantine (Oxford, 1999).

Cottier, M., "The Customs Districts of Roman Egypt," in T. Gagos (ed.), Proceedings of the 25th International Congress of Papyrology (Ann Arbor, 2010) pp. 141-148.

Cracco Ruggini, L., "Leggenda e realtà degli Etiopi nella cultura tardoimperiale," in Atti de IV congresso internazionale di studi etiopici (Rome, 1974) pp. 141-193.

De Laet, S.J., Portorium: Étude sur l'organisation douanière chez les Romains, surtout a l'epoque du haut-empire (Bruges, 1949).

Dihle, A., "The Conception of India in Hellenistic and Roman Literature," Proceedings of the Cambridge Philological Society 10 (1964) 15-23.

DuPont, F., Le acteur-roi ou le théâtre dans la Rome antique (Paris, 1985).

Fosl, T., "Doubt and Divinity: Cicero's Influence on Hume's Religious Skepticism," Hume Studies 22.1 (1994) 103-120.

Fowden, G., Empire to Commonwealth: Consequences of Monotheism in Late Antiquity (Princeton, 1993).

Fowden, E., "Constantine and the Peoples of the Eastern Frontier," in N. Lenski (ed.), The Cambridge Companion to the Age of Constantine (Cambridge, 2001) pp. 377-398.

Gagé, J., "L'empereur romain et les rois: politique et protocole," Revue Historique 221.2 (1959) 221-260.

Girardet, K.M., "Die Petition der Donatisten an Kaiser Konstantin (Frühjahr 313) historische Voraussetzungen und Folgen," Chiron 19 (1989) 186-206.

Gryson, R., Scolies Ariennes sur le concile d'Aquilé (Paris, 1980).

Haas, C., "Mountain Constantines: The Christianization of Aksum and Iberia," Journal of Late Antiquity 1.1 (2008) 101-126.

Hansen, G.C., Sokrates Kirchengeschichte (Berlin, 1995).

Hansen, G.C., Anonyme Kirchengeschichte (Berlin, 2002).

Harmatta, J., "Fragments of Wulfila's Gothic Translation of the New Testament from HácsBéndekpuszta," Acta Antiqua Academiae Scientiarum Hungariae 37.1-2 (1996-1997) $1-24$.

Heather, P., Goths and Romans 332-489 (Oxford, 1992).

Henderson, J., "Women and Athenian Dramatic Festivals," Transactions of the American Philological Association 121 (1991) 133-147.

Humfress, C., "Bishops and Their Law Courts in Late Antiquity: How (Not) to Make Sense of the Legal Evidence," Journal of Early Chrisian Studies 19.3 (2011) 375-400.

Ignjatovic, A., "Byzantium's Apt Inheritors: Serbian Historiography, Nation-Building and Imperial Imagination, 1882-1941," The Slavonic and East European Review 94.1 (2016) 57-92.

Kaldellis, A., "Did the Byzantine Empire Have "Ecumenical” or "Universal" Aspirations?" in C. Ando and S. Richardson (eds.), Ancient States and Infrastructural Power (Philadelphia, 2017) pp. 272-300.

Kauffman, P.I., “Augustine, Macedonius, and the Courts,” Augustinian Studies 34.1 (2003) $67-82$.

Kulikowski, M., "Constantine and the Northern Barbarians," in N. Lenski (ed.), The Cambridge Companion to the Age of Constantine (Cambridge, 2005) pp. 347-376.

Lenski, N.E., "Evidence for the Audientia episcopalis in the New Letters of Augustine," in R.W. Mathisen (ed.), Law, Society, and Authority in Late Antiquity (Oxford, 2001) pp. 83-97.

Luttwak, E.N., The Grand Strategy of the Byzantine Empire (Cambridge, MA, 2009).

Meredith, D., "Annius Plocamus: Two Inscriptions from the Berenice Road," Journal of Roman Studies 43 (1953) 38-40. 
Millar, F., "Emperors, Frontiers and Foreign Relations, 31 B.C. to A.D. 378," Britannia 13 (1982) 1-23.

Milner, N.P., "A New Statue-Base for Constantius II and the Fourth-Century Cult at Oinoanda," Anatolian Studies 65 (2015) 181-203.

Nautin, P., "La conversion du temple de Philae en église chrétienne," Cahiers archéologiques 17 (1967) 1-43.

Obolensky, D., The Byzantine Commonwealth: Eastern Europe 500-1454 (New York, 1971).

Robertson, A. (trans.), “Apologia Contra Arianos," in P. Schaff and H. Wace (eds.), Nicene and Post-Nicene Fathers, Second Series, vol. 4. (Buffalo, NY, 1892).

Rhodes, P.J., "Nothing to Do With Democracy: Athenian Drama and Polis," The Journal of Hellenic Studies 123 (2003) 104-119.

Rives, J.B., "Diplomacy and Identity among Jews and Christians," in C. Eilers (ed.), Diplomats and Diplomacy in the Roman World (Leiden, 2009) pp. 99-126.

Salzman, M., "Elite Realities and 'Mentalités': The Making of a Western Christian Aristocracy," Arethusa 33.3 (2000) 347-362.

Sherwin-White, A.N., Roman Foreign Policy in the East 168 B.C.-A.D. 1 (London, 1986).

Sivan, H., "Wulfila's Own Conversion," Harvard Theological Review 89.4 (1996) $373-386$.

Slootjes, D., "Governor Trumped by Bishop: Shifting Boundaries in Roman Religious and Public Life," in L. de Blois, P. Funke, and J. Hahn (eds.), The Impact of Imperial Rome on Religions, Ritual, and Religious Life in the Roman Empire (Münster, 2004) pp. 219-231.

Stevenson, W., "Sozomen, Barbarians, and Byzantine Historiography," Greek Roman and Byzantine Studies 43 (2002-3) 51-75.

Streitberg, W., Die Gotische Bibel. Band 1: Der gotische Text und seine griechische Vorlage (Heidelberg, 2000).

Thélamon, F., Paiens et chrétiens aux iv siècle: l'apport de l'histoire ecclésiastique de Rufin d'Aquilée (Paris, 1981).

Török, L., The Kingdom of Kush: Handbook of the Napatan-Meroitic Civilization (Leiden, 1997).

Trompf, G.W., Early Christian Historiography (London, 2000).

Weerakkody, D.P.M., Taprobane: Ancient Sri Lanka as known to the Greeks and Romans. Indicopleustoi: Archaeologies of the Indian Ocean (Turnhout, 1997).

Winkelmann, F., Historia ecclesiastica (fragmenta apud Photium): Philostorgius. Kirchengeschichte (Berlin, 1981). 


\section{References}

1 It has become accepted that when using the word "India," ancients meant the far end of the Red Sea, the horn of Africa, and the variety of ports in what we now call India, Nedungatt, 2010. Phillips, 1997, provides an excellent overview of the deep history of Ethiopia's trade connections.

2 Gregory of Nyssa, Contra Eunomium PG 45:264, connects this Theophilus, upon whom he bestows the apparently derogatory epithet "the Blemmyan" (o B $\lambda \dot{\varepsilon} \mu \mu \nu \varsigma)$, with Eunomius's colleague, in Anomaean theology, Aetius. In a vein of rhetorical invective, Gregory states that Theophilus was tied to the group that Constantius's nephew Gallus had put to death including the praetorian prefect of the east, Domitianus, and his quaestor, Montius (Ammianus 14.7). According to Gregory, Theophilus alone survived Gallus's wrath in 354. Philostorgius HE 4.1 adds that Theophilus accompanied Gallus when he was summoned back to the court of Constantius during which the emperor exiled the "Blemmyan" bishop for his support of the rebellious caesar. The mystery of how Theophilus survived both Gallus's and Constantius's disfavor has not been solved. Woods, 1993, pp. 608-610 makes a useful but unsuccessful attempt. The safest conclusion is that Theophilus was politically active in Eastern Roman circles and was a survivor. It is noteworthy that Gregory does not mention Theophilus's mission.

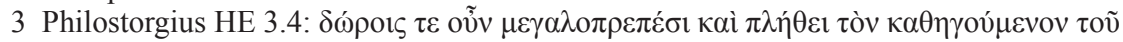

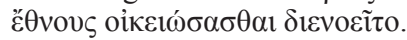

4 The Judaism of Himyar has spurred a good deal of fascinating discussion, Tobi, 2013, Prioletta, 2008, Robin, 2006, Gadja, 2010, and for broader context, Stroumsa, 2015.

5 Loreto, 2012, gives an excellent overview of the bibliography on Himyar.

6 Cerulli, 2012, p. 9, states that the island of Divus is modern Socotra. Diba is Prakrit (a name used for later dialects of Sanskrit) for "island." See below for discussion of archaeological breakthroughs in Socotra.

7 Philostorgius HE 3.6.

8 Youinou, 2008, opens up some interesting speculation on Constantine's possible role in Christianizing east of his empire, though others find the story of Metrodorus, central to Youinou's discussion, close to fictional - for example, Warmington, 1981.

9 An important distinction should be made between the planned, sustained, and systematic exploitation of a colonial economy and occasional plunder. For instance, Strabo, 16.4.22, claims that Augustus sent his expedition under Gallus to find a way to share the mythical wealth of the Himyarites and Ethiopians, but it is not clear in context that the transfer of wealth would come from exacting plunder, receiving gifts, or enhancing trade. Romans habitually participated in all three of these forms of enrichment throughout their history without any colonial project.

10 Mairs, 2008, p. 28, discusses the fascinating role of Greek gymnasia in the cultural "colonization" of the area called Afghanistan today.

11 Ptolemy II initiated the Greco-Roman presence on the Red Sea by mining the area for war elephants and thus, most likely, opening up a lively ivory trade in the mid-3rd century BCE. The best and most comprehensive survey can be found in Seland, 2014. For a Mediterranean perspective, see Desanges, 1969; Burstein, 1996; Ballet, 1996; De Romanis and Tchernia, 1997.

12 Dridi and Gorea, 2003.

13 A bilingual Greek-Palmyrene inscription was found in Berenike and published recently, Dijkstra and Verhoogt, 1999.

14 Hellyer, 2001.

15 Tomber, 2012; Autiero, 2015; Wendrich et al., 2003.

16 Textual evidence of 12 distinct languages have been found in the excavations at Berenike, Seland, 2014, p. 381. 
17 Sidebotham and Zitterkopf, 1995; Sidebotham, 2011; Sidebotham and Gates-Foster, 2018. Religious evidence also points to lively cosmopolitan trade at the time, Sidebotham, 2014. Some textual evidence on Berenike has come to light also: Peppard, 2009; Lunde and Porter, 2004.

18 For instance, Seland, 2014, and Stark, 2012.

19 Ramelli, 2011, emphasizes Pantaenus's role, but within the context of trade routes.

20 Raith et al., 2013.

21 Gadja, 2010. Briquel-Chatonnet, 2010 adds her own fascinating insights into the Christianity in the coastal area of the Arabian Peninsula where one bishop was even a signatory of the Acts of the Council of Seleuceia in 410.

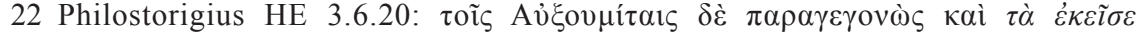

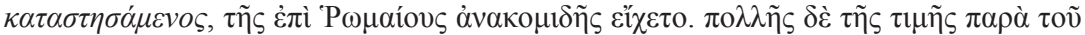

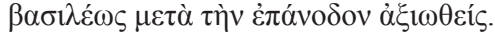

23 There is a fascinating discussion regarding the relationship between Greco-Roman sources and Ethiopian sources on Frumentius. For instance, this piece with a translation of a Ge'ez homily, Haile, 1979; the classic is Selassie, 1972.

24 Sterk, 2010, though focused on women, helps to understand how the captive boys might have fit into the early Christianization of Aksum.

25 Deramay, 1895; Cracco Ruggini, 1974; Dombrowski, 1984; Haas, 2008.

26 Brakmann, 1994.

27 Bausi, 2012, addresses the additional element of language.

28 For the most discussed dissent, Altheim and Stiehl, 1961. In response, Dihle, 1989, and Munro-Hays, 1988, Schneider, 1988.

29 Brakmann, 1994, pp. 68ff.

30 Anfray et al., 1970.

31 Black, 2008.

32 Procopius, Wars 1.19.29-37.

33 Athanasius, Apology to Constantius 31.

34 The date in the Historia Acephala has been widely accepted - for example, Barnes, 1993, p. 119, and Haas, 1991, p. 286.

35 Martin, 1996, p. 503, has the letter arriving in Egypt after May 357. I take this as an implicit argument that Athanasius saw it before it arrived in Aksum. There may also be an implication that it was unconnected with Theophilus's mission.

36 Brennecke, 2007.

37 Athanasius, Apology to Constantius 32.

38 CTh 12.12.2.

39 Strabo 16.4.22-24.

40 Buschmann, 1991.

41 Periplus Maris Erythraei 20. Translation from Casson, 1976.

42 Excavations at Myos Hormos reveal that it was deserted by the Romans in the 3rd century and not revived again as a major port, Cuvigny, 2003.

43 Mayerson, 1996a, p. 122, 1996b; Ward, 2007. The canal leading from the Nile probably was critical for the success of Clysma, but it appears to have silted up from the 3rd century till it was rechanneled by the Umayyad Caliphate in the 7th century, Redmount, 1995.

44 Engels, 1978, esp. Appendix 1. Recent studies have been done by the Pennsylvania State University and University of Kentucky on racehorses both arriving at an average of 30 liters of water per day per horse. The studies establish the bare minimum of five gallons a day unless the horse is gaining fluids from extensive grazing on fresh grass. Ancient horses may have been smaller, but since these were fine specimens and facing desert conditions, the approximation should suffice.

45 Sidebotham and Zitterkopf, 1995.

46 Though sailors certainly have known the reliable seasonal changes of wind and current on the Red Sea for millennia before the author of the Periplus explained them, the 
fascinating oceanographical mechanisms driving them are only recently coming under study, Rasul and Stewart, 2015. Facey, 2002. The international environmental group PERSGA has also made a wide variety of publications available on their website.

47 This region in modern Egypt in summer has an average high temperature of about 100 degrees Fahrenheit with an average low of about 80 .

48 Avi-Yonah, 1951; Borstad, 2008.

49 Philostorgius explicitly mentions these (i $\pi \pi \alpha \gamma \omega \gamma$ oi $\varsigma \pi \lambda$ oíorৎ) HE 3.4.

50 Thucydides History 2.56 for Pericles and History 6.43 for 30 horses per ship. Later in the war, he describes a similar tactic with 200 horses, History 4.42.

51 Plutarch, Life of Pyrrhus 15. Those familiar with the history of the Punic Wars will remember the massive use of horse transports (e.g., Polybius History 1.27.9 - i $\pi \pi \eta \dot{\gamma}$ or), as well as Belisarius's expedition to Africa (Procopius Wars 3.11), and on into Crusader tales, Martin, 2002.

52 Burstein 1996, argues that elephant hunting shifted from the Red Sea to interior Africa and India in the 2 nd century BCE, though the ivory trade carried on.

53 ChT 12.12.2. Chapter 4 will be dedicated to explicating this rich and perplexing document.

54 Because of the testimony from Periplus quoted above, it is clear that most if not all watering and foraging would be performed on the Egyptian shore of the Red Sea. Following our current knowledge of the few port towns along this shore, it seems likely that the horse transport ships would have had to be able to store a good deal of forage and water for runs of three or more days at sea.

55 The march from the ports of Mouza or Adane to Zafar is roughly 150 miles.

56 The medieval port of this city, Mocha, became famous for its coffee in the early-modern period.

57 This calculation is rough, and it is complicated by the regular monsoon winds on the Indian Ocean blowing westward across the Arabian Sea in the winter and reversing eastward in the summer. If the mission did sail down the east coast of Africa (modern Somalia) as suggested by Philostorgius, this would be done in the winter, and the sail back would be in the summer.

58 The date in the Historia Acephala has been widely accepted - for example, Barnes, 1993, p. 119, Haas, 2006, p. 286, and Martin, 1985.

59 Haas, 2006, pp. 282-294, supplies great detail and provocative theories on this important episode.

60 Periplus 23 calls the Himyarite king "Friend of the Emperors" for his frequent embassies and gifts, presumably throughout the 1 st century CE, so Constantius was reviving an established Roman pattern.

61 Sterk, 2010, p. 11, brings to light an alternative story of Theognasta who reportedly converted Himyar in the 5th century.

62 Munro-Hays, 1991.

63 This episode is discussed in Chapter 3.

64 Athanasius denied this charge, Apology to Constantius 6-11, but admitted that he unsuspectingly received Magnentius's envoys, the bishops Sarvatius and Maximus, among others. In the context of the length, detail, and vehement rhetoric of this denial sent in early fall 357 and of the sharp reversal of tone to hostility against Constantius in the History against the Arians published a year later, suspicions easily arise. In fact, History of the Arians 74.4 openly names Magnentius as a legitimate emperor (basileus) along with Gallus and Vetranio. But the fact that Magnentius sent such a high-level embassy to Athanasius, that Athanasius admitted receiving it, and that Constantius recognized this embassy with a public accusation is more than enough to prove that the emperor perceived Athanasius as a rebel (or at least wanted it on the public record that Athanasius was accused of collusion with Magnentius). Martin, 1996, pp. 464-473, treats this episode in impressive depth. 
65 Haas, 2006, pp. 282-294.

66 Ammianus Marcellinus 22.11.

67 Recent work clarifies that the Sasanid economic interest in Himyar was fading at the time of Constantius's mission, Kennett, 2007.

68 Procopius Wars 1.20.9.

69 Cracco Ruggini, 1974, pp. 185-188.

70 Chapter 7 discusses identity in depth.

71 The pragmatic nature of Constantius's court is argued in depth in Chapter 3.

1 Barnes, 1993, p. 145, where the narrative appears intent upon emphasizing that Athanasius had no reason to complain about his treatment at the hands of his "anti-Christ" Constantius, since such treatment remained consistent with that of all bishops under the "orthodox" Constantine. Girardet's work emphasizes the universality of Constantine's precedents by underlining a consistent, rational, and long-lasting juridical basis for the interactions between emperors and bishops. Girardet, 1974a, 1974b, 1975, 1989, 1994, 2007, 2009, 2010. Wirbelau, 2008, though following Girardet closely, finds one exceptional case, the bishop of Rome Liberius's exile, which, he argues, set new precedents for later imperial usage. Fournier, 2006, provides a fascinating analysis of the next generation of exiled bishops after Constantius's reign.

2 The analysis in this paper is influenced by Van Dam, 2007, p. 13: "Being a Christian emperor certainly raised practical problems for Constantine, for instance about his readiness to use coercive force or his attitudes toward bishops." Van Dam succeeds in demonstrating best how the bishops, especially Marcellus of Ancyra and Eusebius of Caesarea, developed innovative methods for manipulating emperors - for example, 286-293. The book leaves us to wonder if Constantine had formed "policy" for disciplining disruptive bishops. My enormous debt to Barnes, 1993, and Brennecke, 1984, will be obvious, as it is to all studying the reign of Constantius.

3 Henck, 2001, presents a new perspective on Constantius's ambitious, and often overlooked, building program.

4 Barnes, 1993, p. 145.

5 Rapp, 2006, p. 262, wisely qualifies her position: “Constantine's response usually consisted in referring the matter to a meeting of bishops, the decision of which he declared binding (italics are mine)." Drake, 2000, pp. 106-107, states it more directly: "Decrees of synods could not be enforced and could be contradicted by synods elsewhere. The only criteria for adjudicating between councils that reached contradictory conclusions were informal, with certain sees being accorded wider prestige than others because of the fame or antiquity of their community. ... In the decades following Constantine, this lack of clear criteria for precedence and jurisdiction will become a cause of frequent turmoil."

6 Two colorful examples of Constantius's influence can be found in the treatment of John Chrysostom by Arcadius's court (Chapters 5 and 6) and the North African bishop Fulgentius by the Vandal king Thrasamund (Chapter 9).

7 Washburn, 2013, p. 1.

8 Washburn, 2013, pp. 82-97. Washburn argues that banishment was intended to reform as well as remove undesirable bishops. I will treat the first two efforts at "reform" less generously as reeducation.

9 Epiphanius Panarion 2.92. Most assume that Marcion was a suffragan bishop under his father in Sinope, and he surely took on the role of bishop in his subsequent evangelism.

10 The literature on early Christian "discipline" does not seem vast. Washburn provides a bibliography, but in addition to his list, I found Pfeiffer, 2003, and Hein, 1975. The bibliography on ancient exile has been growing recently but is still mostly focused on the practices of city-states and literary reactions to these practices: most interesting, in addition to Washburn's list, is Bladeau, 2008, and Stini, 2011. See also Gorman, 1994.

11 For example, Romans 16:17-18 and 1 Corinthians 5. 
12 Wirbelau, 2008, pp. 38-40, discusses the interesting cases exposed by the Chronograph of 354 .

13 Rolfe, 1914, pp. 220-222, and Fisher, 1977, pp. 3-4.

14 Canon law discussions have gone into great detail on this issue. Girardet, 1974a, pp. 87-88, surveys a good deal of this discussion and concludes: "Du point de vue du droit processif, le 'Reichssynode' fonctionne comme un consilium du iudex public; ainsi la compétence juridique des évêques, en tant que consiliarii, se limite à connaître de la question de culpabilité, ils ne peuvent pas prononcer une sentence pénale exécutoire. ... Enfin le iudex terrenus (emperor) qui dirige le procès prononce la sentence pénale en se basant sur la culpabilité reconnue par les évêques-consiliarii, sentence frappant non pas un évêque en fonctions, mais un homo privatus." How clearly such a process was understood in the period from 337 to 361 opens a question more pertinent to the topic of this paper.

15 Washburn, Banishment, 16-40, delivers a magisterial overview of the history of Roman exile language and, in particular, the complexities of legal terms in Latin.

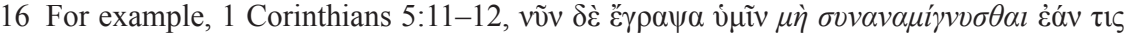

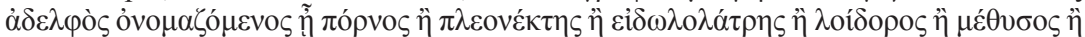

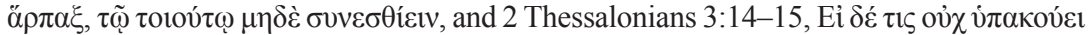

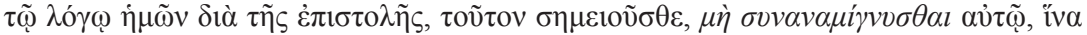

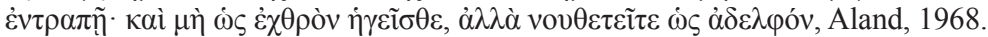

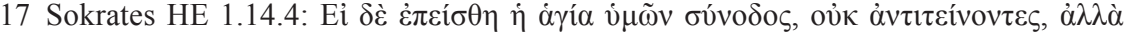

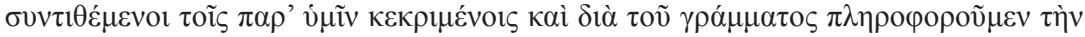

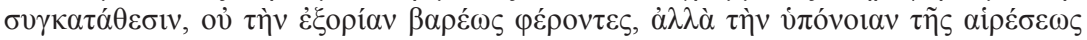

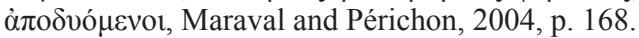

18 We see the earliest evidence of this tendency in this letter from the Council of Nicaea to the city of Alexandria, in this section passing judgment on Meletius, Urkunde 23.6, Opitz, 1934, vol. 3, pp. 48-49: "The Council took pity on Meletius, although strictly speaking he was wholly undeserving of favor, and decreed that he remain in duty in his own city but exercise no authority either to ordain or nominate for ordination; they also moved that he appear in no other district or city on this pretense, retaining no more than the normal level of authority" (Translation adapted from the "Fourth Century Christianity" website: www.fourthcentury.com/urkunde-23/). In this letter, they explicitly refuse to restate their condemnation of Arius, Secundus, and Theonas. But in Eusebius's and Theognis's letter of repentance, they use the official language of exile, Urkunde 31, Opitz, 1934, vol. 3, p. 65.

19 Washburn, 2013, pp. 48-49, tersely sums up Constantine's record. The sources are not in agreement on what happened to Arius's episcopal colleagues after Nicaea. The ecclesiastical historians agree that the council forbid his supporters, Secundus of Ptolemais and Theon of Marmarica, from returning to their episcopal homes, Philostorgius HE 1.9 and Theodoret HE 1.6. Sokrates HE 1.8 adds a few more depositions to the list. Eusebius's Life of Constantine is silent concerning exile and very positive that Constantine's exhortations to harmony were successful, VC 2.17-23. Barnes, 2009, asserts that Constantine did exile Arius and argues at length against Brennecke et al. regarding the dates of readmission into communion/imperial favor. See also Sozomen HE 2.27 on Constantine's reconciliation with Arius. At the least, it is safe to say that we have little solid evidence to discuss Constantine's practice of exiling bishops.

20 Washburn, 2013, p. 48, calls attention to Constantine's innovation in sending threats of banishment to bishops.

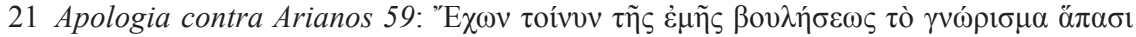

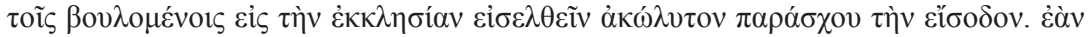

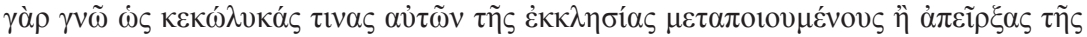

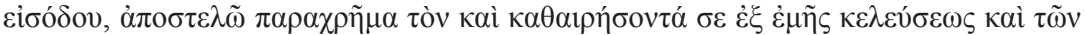

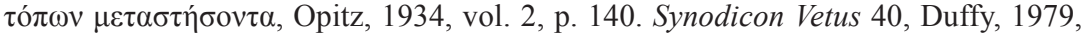




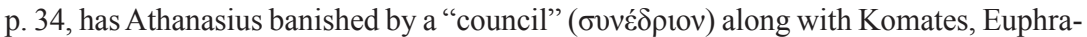
tes of Antaradus, Euprepius of Adrianople, Lucius the Confessor (of Adrianople), and Marcellus of Ancyra.

22 Washburn, 2013, pp. 46-52. An emperor's unilateral exile of a bishop would undermine the 5th canon of the Council of Nicaea. On the other hand, the tradition of canon law has argued that the emperor, from the first precedent of Constantine, had the duty to sentence and execute sentence after a synod made its ruling, Girardet, 1974.

23 Barnes, Eusebius and Constantine, 214. Sokrates HE 1.11, Maraval and Périchon, 1:142-144; Sozomen HE 1.10, Bidez and Hansen, 22. Not surprisingly, for ideological reasons, Eusebius does not mention Paphnutius in his Ecclesiastical History or Life of Constantine.

24 Rufinus HE 10.4, PL 21:482: "Constantine thought of him with such respect and affection that many times he called him into the palace, hugged him, and warmly kissed the eye which had been gouged out during his confession of faith."

25 Licinius, of course, was officially exiled before he was murdered. On the other hand, Constantine started his own career with a reputation for recalling those exiled by Maxentius (Eusebius VC 1.41) and appears to have resisted using exile as a political punishment.

26 Of course, Arius was not a bishop, so his case lies outside this study.

27 The longest list of bishops here that is only found in Sokrates HE 1.8.

28 A close reading of Sokrates HE 1.9; Maraval and Périchon, 1:112-140; and Sozomen HE 1.23 reveals a part of the edict that has been understood to contain the command of banishment. It orders Arius's publications to be burned and anyone harboring a copy to be killed, but the extant quotation says nothing of exile. In addition, the document that indicates Arius's restitution several years later makes no mention of exile. Only a letter from Constantine to the Nicomedians found in Athanasius's De Decretis Nicaenai Synodi 41 (Urkunde 27.15, Opitz, 1934, vol. 3, p. 62) states "on this account (that Eusebius had harbored Arius and accomplices) I decided to do this regarding these thankless men:

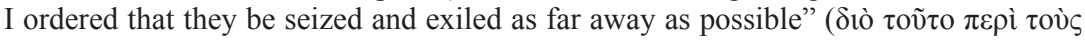

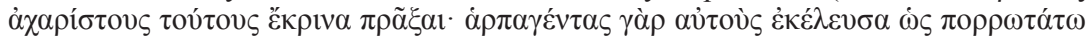
$\dot{\varepsilon} \xi$ opı $\theta \tilde{\eta} v \alpha 1)$. Barnes, 2009, p. 125, cites Schwartz, 1959, vol. 3, pp. 202-203 for a reconstruction that Arius was not exiled but ordered to live in Nicomedia. Schwartz trusts his interpretation of Urkunde 27.15-16 more than the testimony of Philostor-

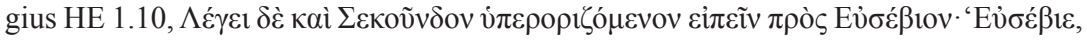

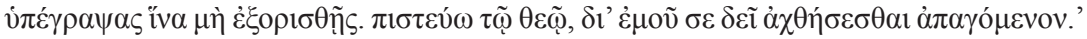

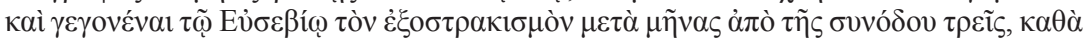

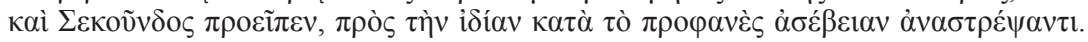
The latter implies that Arius was exiled along with his faithful ally Secundus. Schwartz also cites Bidez, 1913, p. 11, where Niketas Choniates's Thesaurus Orthodoxiae Fidei is quoted to give a location of exile (Latin translation available in PG 139:1369). The passage will be difficult to find in Greek and is worth quoting: oi $\delta \dot{\varepsilon} \gamma \varepsilon \pi \varepsilon \rho \grave{~ E v ̉ \sigma \varepsilon ́ \beta ł o v ~}$

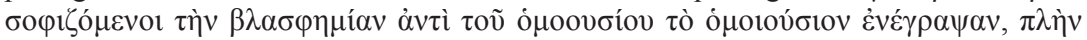

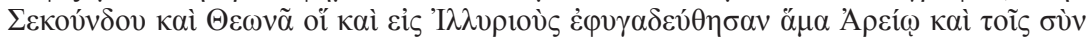

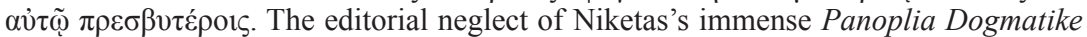
(translated to Latin and excerpted in PG 139 as the Thesaurus) makes it difficult to assess the credibility of his witness, Simpson, 2013, p. 36.

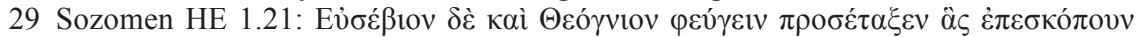
$\pi 0 ́ \lambda \varepsilon 1 \zeta$.

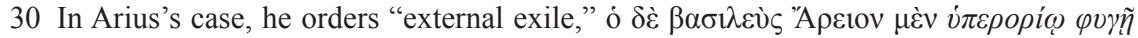

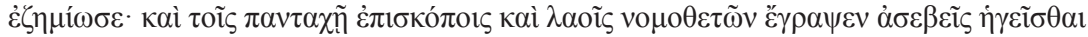

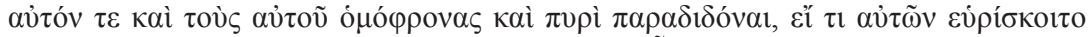

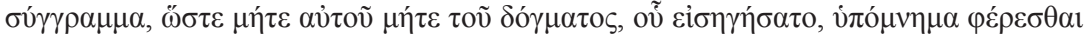
(Sozomen HE 1.21). Was there to be a hierarchy of exiles with the heresiarch suffering a more severe punishment via distance? Then why not specify whither Arius must be sent? 
Or is Sozomen anachronizing the policies of Constantius, or more likely of Theodosius, back onto Constantine as Van Dam, 2007, p. 342, implies? The phrase "external exile"

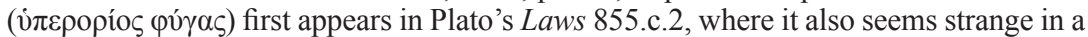
work dedicated to expounding dozens of kinds of exile, all outside of the convict's $\pi$ ó $\lambda$ is. Sozomen may be indulging his literary penchant by alluding to Plato, but the phrase still draws a deliberate distinction from the exile of Eusebius and Theognis.

31 Sozomen HE 8.8. CTh 16.5.6 in Chapter 5.

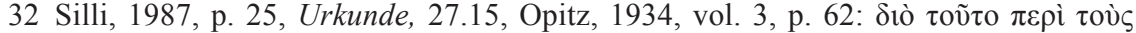

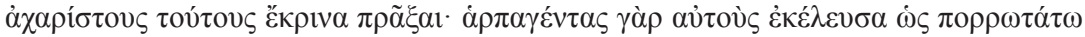
$\dot{\varepsilon} \xi$ opı $\sigma \theta \tilde{\eta} v \alpha$. The context of the letter could easily be read to lead to different conclusions: a) Constantine had not originally exiled the Arians but requested them to come to his court; b) those ordered into exile in this letter appear to be not only Eusebius and his allies but also the Arians with him; c) if so, then Constantine's order of exile appears not to follow from the Council of Nicaea but rather as an imperial response to direct disobedience by all the bishops involved, both Alexandrian and Nicomedian.

33 Barnes, 2009, p. 125; Schwartz, 1959, vol. 3, pp. 202-203.

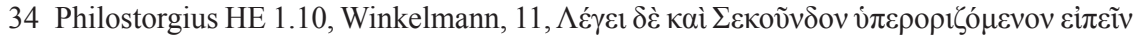

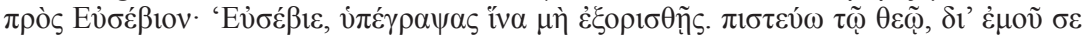

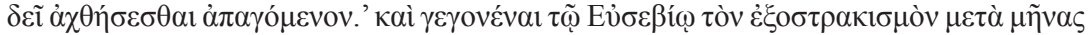

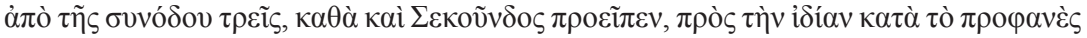

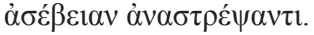

35 Mayer, 2010, pp. 161-162, describes the use of praetorian guardsmen to force John Chrysostom on his way east into exile in 404 during which march he wrote to influential friends to find out what his eventual destination would be. Whether or not we can project such a mechanism back onto Constantius's first banishments remains difficult to say.

36 Parmentier and Scheidweiler, 1954, p. 89.

372 Samuel 16.

38 Van Dam, 2007, pp. 339-342.

39 Barnes, 1996, pp. 550-555, argues that Sozomen is a trustworthy source to demonstrate that, for instance, mid-4th-century bishops were instructing local military officials to execute exiles voted in by synods. I would tend to side with Van Dam that almost all of Sozomen's depiction of exile reflects his 5th-century experiences.

40 This episode is chosen as late in Constantine's reign. An excellent discussion of his first disinclination to exile a bishop, Caecilianus, has been elaborated: K. M. Girardet, 1989. Parvis, 2006, provides a full treatment of Marcellus's see.

41 Barnes, Constantine, 240-242. Recent discussions of Athanasius's theological opponents have left us without any useful names for the various groups beyond the tendentious "Anomian," "Arian," "Eusebian," and so on, while the less rhetorical homoousian/ homoiousian/heteroousian terminology fails to capture the shifting distinctions in factions so important to this study. Sokrates 2.41, Maraval and Périchon, 2:218-222, list eight groups, leaving us with a much more complex situation than Athanasians vs. Arians or Nicenes vs. Eusebians. Gwynn, 2006, is a good place to start figuring out how to name the various factions. For the purposes of this paper, I will uncomfortably use traditional names like Eunomian, Eusebian, Nicene, and Semi-Arian to separate the various possible groups. The record reveals more flexible views for our leading bishops than either ancient or modern commentators are comfortable with.

42 H. Drake, 2000, pp. 314-315, reconstructs a group of bishops chasing Athanasius to Constantinople after the Council of Tyre, who call his bluff in the presence of Constantine.

43 H. Drake, 2000, p. 314, reads this "exile" as Constantine's effort to cool Athanasius off. 44 Apology against the Arians 87, Opitz, 1934, vol. 2, pp. 166-168.

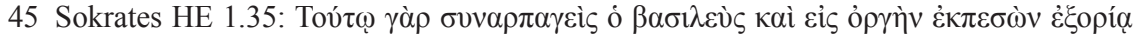

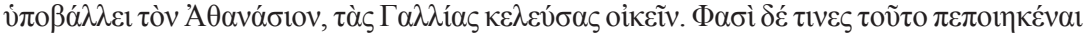




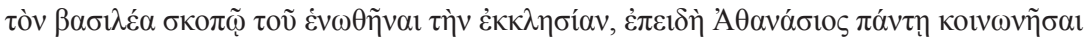

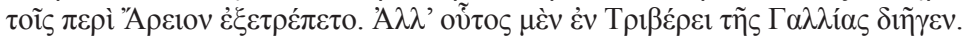

46 Wirbelau, 2008, pp. 32ff., following Girardet, brings up the case of Constantine adjudicating between the feuding bishops of Carthage, Caecilianus, and Donatus, in 313 - a good example to show precedent for calling a sort of local juridical synod to advise the emperor. But the case did not produce a verdict of exile, even though an efficient, distant, and permanent exile of Donatus may have saved Constantine and following emperors trouble.

47 Barnes, 1993, p. 212.

48 Barnes, 1993, p. 214.

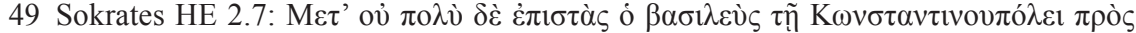

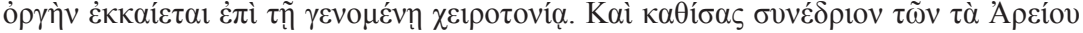

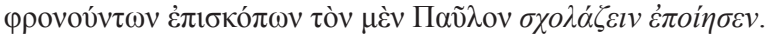

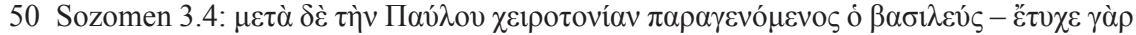

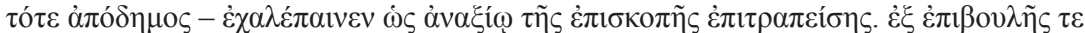

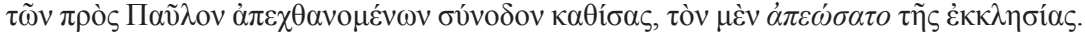

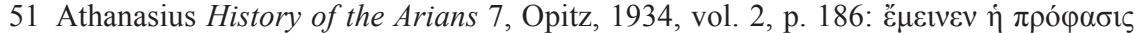

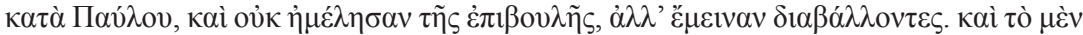

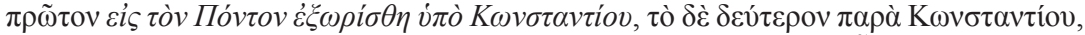

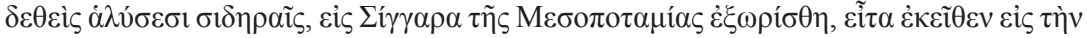

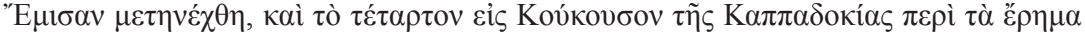

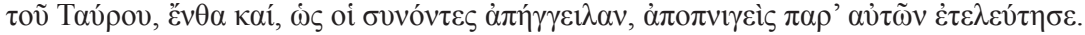

52 Barnes, 1993, p. 213, Sokrates HE 2.12, Athanasius Apology against the Arians 21-35, Opitz, 1934, vol. 2, pp. 102-113.

53 Sokrates HE 2.13, Sozomen 3.7, Athanasius History of the Arians 7, Opitz, 1934, vol. 2, p. 186.

54 Libanius Oration 59, Foerster, 1908, pp. 256-257, translation from Lieu and Montserrat, 1996, p. 186.

55 Barnes, 1993, pp. 219-220, CTh 3.12.

56 Athanasius's detail, History of the Arians 7, Opitz, 1934, vol. 2, p. 186, that Paul was escorted bound in chains stands out as the greatest embellishment of that passage.

57 Barnes, 1993, pp. 63-70.

58 Rapp, 2006, p. 254, discusses canon 8 of the Council of Serdica. She points out its intent to regulate the number of bishops visiting the imperial court by requiring that bishops could only make such a visit with the emperor's invitation. Surely there was a wish from the court to control the constant flow of bishops, but as Rapp goes on to discuss, the canon was not enforced. As this chapter shows, bishops freely flowed to the court in a constant stream. She discusses the details of travel cost and hospitality on pp. 265-266.

59 Barnes, 1993, p. 84. Murder of, and murder threats toward, bishops will not be discussed in this chapter, though killing could be seen as simply a more sudden and permanent form of exile.

60 Barnes, 1993, p. 214. Note that Sokrates HE 2.16, states that Paul was banished to Thessalonike while Athanasius's enthusiastic passage from History of the Arians 7, Opitz, 1934, vol. 2, p. 186, had the third exile to Emesa in Syria. Barnes, 1993, pp. 215-216, emends the text to mean that Paul went to the court of Constantius in Emesa in his 4th exile whence he was sent to Cucusus in Armenia where he was reportedly strangled.

61 As above, Athanasius History of the Arians 7, Opitz, 1934, vol. 2, p. 186, states Emesa in Syria, while Sokrates 2.16, states Paul ended up in Thessalonike. Barnes, 1993, p. 214.

62 Barnes, 1993, p. 91.

63 Barnes, 1993, p. 92.

64 Negotiations between Magnentius and Athanasius would certainly have underscored competition between the emperor and his main ecclesiastical enemy. Haas, 1997, p. 461, 
n. 10, cites Zosimus 2.51-52, Epitome de Caesaribus 42.4-8, and Eutropius 10.12 in his discussion of Alexandrian unrest in the 350s.

65 Gentili, 1992, pp. 192-208, supplies interesting insights on the conflict from the perspective of the localities.

66 Girardet, 1974a, pp. 63-91, carefully attempts to reconstruct the edict issued after the Council of Arles.

67 Suda, s.v., praises Agapetos, bishop of Synnada, and comments on Eusebius of Caesarea's great admiration for his miracles. Agapetos may have been seen as loyal to the court of Constantine and thus trustworthy as a host for exiled bishops.

68 Hilary of Poitiers, Contra Constantium 11, Rocher, 1987, p. 190, Crouzel, 1976, pp. 180-181. Beckwith, 2005, pp. 27-28. Sulpicius Severus Chronicle 2.39, de Senneville-Grave, 1999, p. 314.

69 Sulpicius Severus Chronicle 2.45.

70 Fiedrowicz, 2010, pp. 149-164, provides a fitting epitaph for this heroic bishop.

71 Ammianus 15.7, Seyfarth, 1978, pp. 55-57, cleverly juxtapose Constantius's heavyhanded treatment of Liberius, bishop of Rome, with the elevation of Julian.

72 Barnes, 1993, p. 116.

73 Scholars as from Barnes, 1993, p. 116, to Crouzel, 1976, pp. 184-185, accept Severus's comment: "igitur cum sententiam eorum, quam de Athanasio dederant, nostri non reciperent, edictum ab imperatore proponitur, ut qui in damnationem Athanasii non subscriberent, in exsilium pellerentur." (Chronicle 2.39) But right before this, Severus tells the story of how Valens of Mursa fooled Constantius into thinking his victory over Magnentius was due to the emperor's holiness: "facilis ad credendum imperator palam postea dicere solitus, se Valentis meritis, non virtute exercitus vicisse." (Chronicle 2.39).

74 Barnes, 1993, pp. 118-119.

75 Barnes, 1993, pp. 118-120.

76 Crouzel, 1976, pp. 175-176.

77 Crouzel, 1976, p. 178, sorts out Sokrates's and Sozomen's assertion of Dionysius's see as Alba.

78 Hilary To Constantius 8, PL 10:562: Conventus ut in Athanasium subscriberet, ait, De sacerdotali fide prius debere constare; compertos sibi quosdam ex his qui adessent, haeretica labe pollutos. Expositam fidem apud Nicaeam, cuius superius meminimus, posuit in medio: spondens omnia se, quae postularent esse facturum, si fidei professionem scripsissent. Dionysius Mediolanensis Episcopus chartam primus accepit: ubi profiteri scribendo coepit, Valens calamum et chartam e manibus eius violenter extorsit, clamans non posse fieri, ut aliquid inde gereretur. Res post clamorem multum deducta in conscientiam plebis est: gravis omnium dolor ortus est, impugnata est a sacerdotibus fides. Verentes igitur illi populi iudicium, e Dominico ad palatium transeunt. cuismodi sententiam in Eusebium longe ante quam ecclesiam ingrederetur scripserint: de se loquitur ipsa sententia (end of the letter).

79 Athanasius Apology to Constantius 27, Brennecke, 2006a, 2006b, p. 301; Theodoret HE 2.12 .

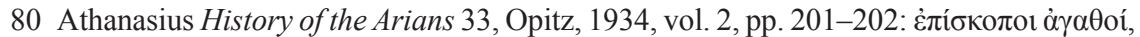

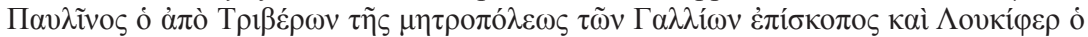

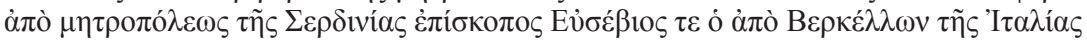

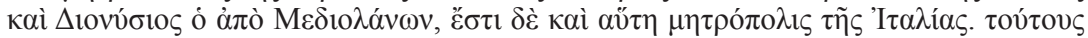

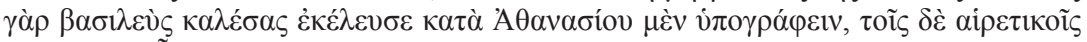

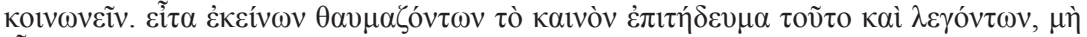

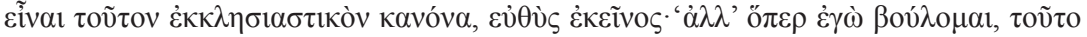

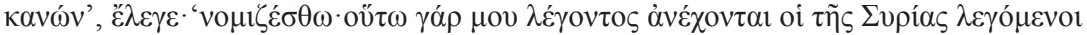

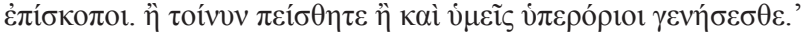




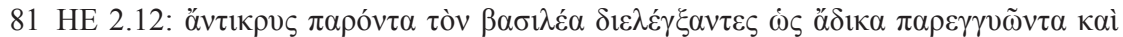

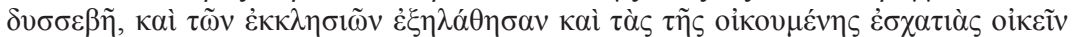

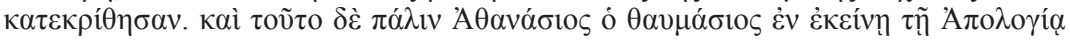

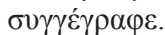

82 Sulpicius Severus Chronicle 2.39: illinc epistolam sub imperatoris nomine mittunt, omni pravitate infectam, eo nimirum consilio, ut, si eam aequis auribus populus recepisset, publica auctoritate cupita proferrent; sin aliter fuisset excepta, omnis invidia esset in rege, et ipsa venialis [quia etiam tum catechumenus sacramentum fidei merito videretur potuisse nescire]. igitur lecta in ecclesia epistola populus aversatus. Dionysius, quia non esset assensus, urbe pellitur, statimque eius in locum Auxentius episcopus subrogatur.

83 Sokrates HE 2.37: "When the emperor learned (what had happened at Milan), he used

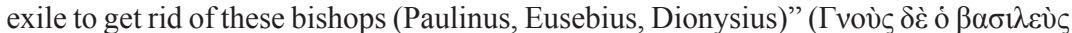

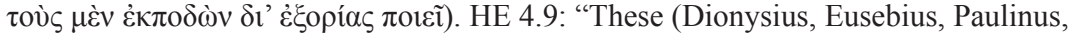
Rhodanus and Lucifer) were convicted to exile for speaking so directly, and Hilary

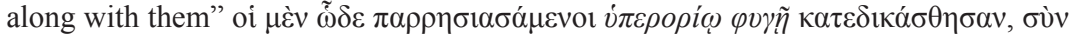

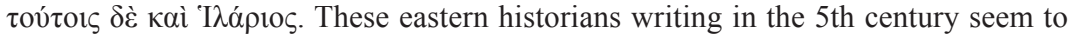
have compressed Athanasius's writings and thus have left us a muddled narrative of councils from Arles to Constantinople. Hilary of Poitiers Contra Constantium 2.3-6, places Dionysius clearly in the post-Milan exile group.

84 Speller, 1985, pp. 157-165, pulls sermons of pseudo-Maximus of Turin into a wellformulated mystery surrounding Dionysius's role at the Council of Milan.

85 Dattrino, 2010, pp. 699-720.

86 Washburn, 2009, pp. 731-755.

87 Ammianus 19.12.5, remarks on convenient remoteness. Washburn, 2009, p. 733, conflates chronology a bit. He connects Eusebius's exile to Ammianus's description of Constantius's horrifying treason trials held in Scythopolis in 359, quite possibly after Eusebius had escaped to Egypt.

88 Tietze, 1976.

89 Summary at PL 13:744. Tietze, 1976, pp. 61-66.

90 Sokrates HE 2.37 describes Eudoxius maneuvering to become the Eusebian bishop of Germanicia, and Epiphanius Panarion, Holl, 1922, vol. 3, p. 302, describes the antiAthanasian bent of Eutychius.

91 Sokrates HE 2.19, Eudoxius delivers the Eusebian creed to Milan in 355; HE 2.37, he requests Constantius to grant him leave from the court to tend to affairs in Germanicia around the beginning of 358 .

92 Amm. Marc. 15.7.

93 Theodoret HE 2.13.

94 Corroborated by Philostorgius HE 4.3.

95 T.D. Barnes, 1992a.

96 Brennecke, 1984, pp. 266-269. Also Mirri, 2003, provides an overview of issues at Biterrae.

97 Crouzel, 1976, p. 182.

98 History of the Arians 34-41, Opitz, 1934, vol. 2, pp. 202-206.

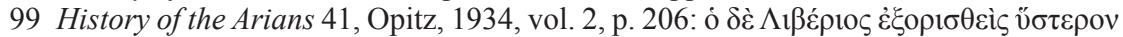

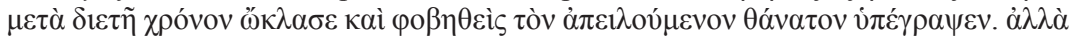

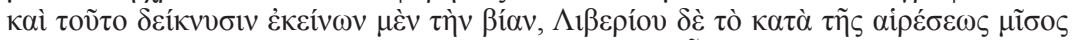

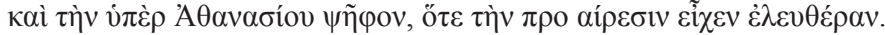

100 Brennecke, 1984, p. 268.

101 Sozomen HE 4.15: "the bishops convened at Sirmium wrote . . whatever illegalities might have occurred in the ordination of Felix, or the banishment of Liberius, can be buried in oblivion." See Note 63 above on Athanasius's flirting with Magnentius.

102 For Hilary as the "Athanasius of the West" Barnes, 1992b.

103 Beckwith, 2008, summarizes the history of the discussion and argues for a Christian motive. 
104 Barnes, 1993, p. 141, and Crouzel, 1976.

105 See Note 67 above.

106 Rhodanius's death is included with Paulinus's at Sulpicius Severus Chronicle 2.45.

107 For instance, in De Synodis 90, PL 10:542-543, Hilary, writing to Basil of Ancyra shortly after the publication of the Council of Ancyra's moderate formulation, mentions that bishops have brought him a copy. Beckwith, 2008, brilliantly reconstructs Hilary's intellectual (and political) context during exile when the De Trinitate was edited into its current form.

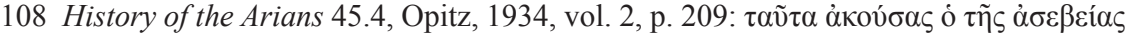

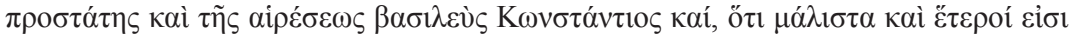

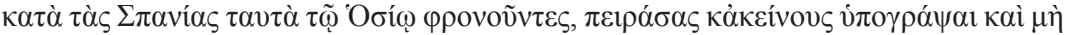

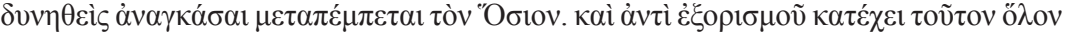

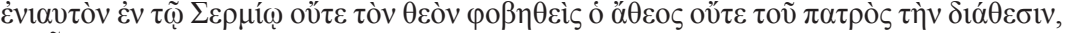

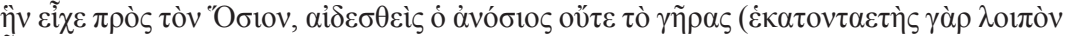

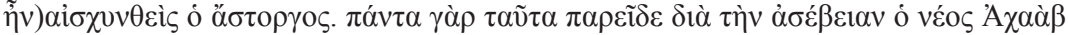

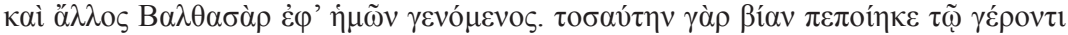

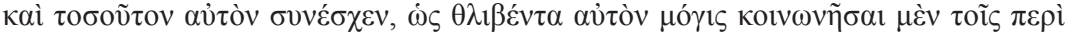

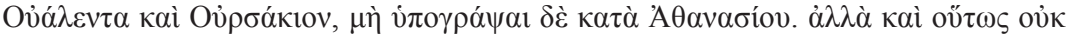

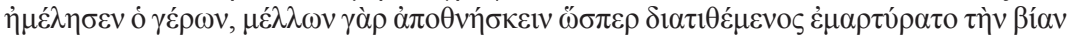

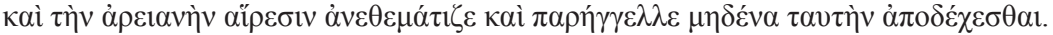

109 Amm. Marc. 16.10: Constantius left Rome on May 29 to fend off attacks in Pannonia. Ammianus mentions Ursicinus being first called east to Sirmium to help out and then being sent further east, along with the young Ammianus, to prepare for a Persian campaign. The narration makes it unlikely that Constantius left trusted officers in Sirmium and strongly implies that his attention was turned toward Julian's successes in Gaul.

110 Germinius earned villain status in an extant text purporting to report a dialogue between him and a lay member of his flock, Heraclianus, Caspari, 1883, pp. 133-147. One line rings true in our context when Heraclianus charges: tu, qui pro scandalo hoc in populo praedicas, et Graece nosti dicere. Germinius's importation from the Greekspeaking East may well have caused a grudge among the parochial Illyrian Christians.

111 Sozomen HE 4.12, Athanasius History of the Arians 45, Opitz, 1934, vol. 2, p. 209,

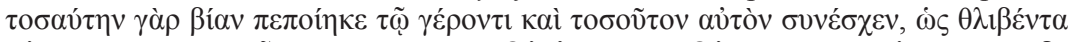

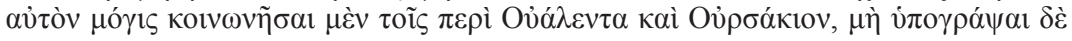

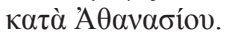

112 Sozomen HE 4.12.

113 Hilary's production of the De Synodis and De Trinitate during his Phrygian exile seems to demonstrate a breakdown in the Phrygian exile strategy that had martyred Paulinus and Dionysius. On a more speculative note, the compromises forged by Hilary with his Galatian neighbor Basil of Ancyra may explain why this particular exile was less rigorous. At least equally likely, Hilary's prominence required a different treatment.

114 Sozomen HE 4.12.

115 Beckwith, 2008, p. 57. Sokrates HE 2.39; Sozomen HE 4.13.

116 Sokrates HE 2.39-41. Sozomen confuses the chronology HE 4.12ff. Cyril of Jerusalem is caught in the middle of this factionalism, suffering exile at his rival Acacius's hands, apparently, H.J. Drijvers, Cyril of Jerusalem: Bishop and City (Leiden, 2004), Kalleres, 2005.

117 Sozomen HE 4.14.

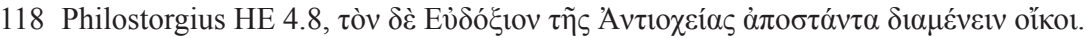

119 Kelly, 2004, p. 222, underscores the role of whispering campaigns, especially among the women in the court.

120 Woods, 1991, p. 289.

121 Phil HE 4.8.

122 Phil HE 4.8: "He says that Basil, having taken with him Eustathius, bishop of Sebaste, and other leaders of the churches, brought charges to the emperor against Aetius and 
Eudoxius, alleging various things, but especially that they were aware of the conspiracy against Gallus, and had actually participated in it. Theophilus too was implicated in the same series of charges. The emperor believed the story of Basil, which was supported by the women, whom Basil had already brought over to his side, and accordingly sentenced Theophilus to exile, and banished him to Heraclea on the Pontus, while he ordered Eudoxius to leave Antioch, and to keep himself within his own house. . . Eudoxius retired into Armenia, his native country. Others also, up to seventy, were condemned by the testimony of Basil and his party, and were sent into exile."

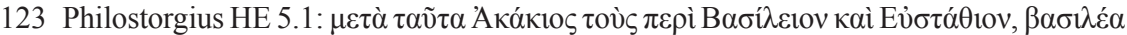

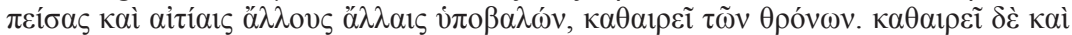

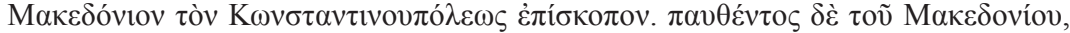

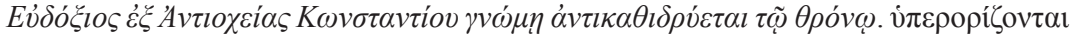

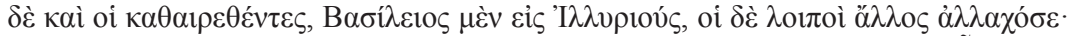

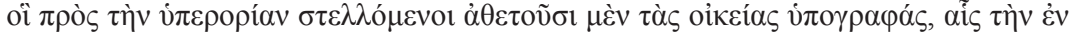

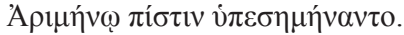

124 Barnes, 1996, p. 550.

125 In the category of threatening exile, I pass over the technique of holding whole councils hostage until all the bishops sign. Barnes, 1993, p. 145 (esp. n. 11) says Constantius held bishops against their will for months at Ariminum. Sulpicius Severus Chronicle 43: ita dimissis legatis praefecto mandatum, ut synodum non ante laxaret quam conscriptae fidei consentire se omnes subscriptionibus profiterentur: ac, si qui pertinacius obsisterent, dummodo is numerus intra quindecim esset, in exsilium pellerentur.

126 Girardet, 1974a, pp. 90-91, spells out a case for Constantius's legal right to proceed against Athanasius under a crimen laesae maiestatis, which could easily cover Athanasius's dealings with Constans, Magnentius, and Constantius. It may be pointed out that Liberius also was returned to his original see, but I would contend that he showed opposition to the Council of Ariminum and would have proven even more difficult, if Constantius had maintained influence in Rome beyond Julian's ascent to Augustus in the winter of 360.

1 While some may see this argument as an attack on the carefully focused points in classic works the likes of Lee, 1993, and Austin and Rankov, 1995, this is not the case. Though both may overemphasize the point that organized systematic intelligence was unknown to the Romans, the emphasis on Constantius's mobilization fits into their conceptions of ad hoc intelligence collection. In addition, this study, by focusing on individuals and their strategies has little to say about the generalizations of previous scholars. Sheldon, 2003, provides an essential overview of the literature on the topic.

2 Sozomen HE 4.10 tells a plausible story of Athanasius deceptively eluding his pursuit by sneaking back into Alexandria.

3 Synesios of Cyrene, ep. 122 (Hercher, 1873), mentions the battle valor of the Aksumite priests. Though the episode described must have happened 50 years later, and though we wonder why priests from Aksum are taking part in skirmishes in Libya, it is tempting to project back into the 350 s the mettle of Athanasius's clergy. This episode is discussed in Chapter 8.

4 The scholarly tradition has accepted the date of January 15, 356, but Mommsen's proposed revision will be considered at the end of the chapter (Mommsen, 1905, vol. 1.2, p. 726).

5 Codex Theodosianus 12.12.2: "Idem (Constantius) aa. et Iulianus c. Musoniano praefecto praetorio. nullus ad gentem Aksumitarum et Homeritarum ire praeceptus ultra annui temporis spatia debet Alexandriae de cetero demorari nec post annum percipere alimonias annonarias. dat. xviii kal. feb. Mediolano indictione xv Constantio a. viii et Iuliano c. conss. (356 ian. 15)." Mommsen, 1905, vol. 1.2, p. 726: "Idem (Constantius) aa. et Iulianus c. Musoniano praefecto praetorio. nullus ad gentem Aksumitarum et Homeritarum ire praeceptus ultra annui temporis spatia debet Alexandria decedens inde morari nec post annum percipere alimonias annonarias. dat. xviii kal. feb. Mediolano 
indictione xv Constantio a. viii et Iuliano c. conss." (underlining added) Mommsen's more accurate rendition of the dating reveals another problem. Both problems are addressed at the end of the chapter, building on the exposition to follow.

6 Moser, 2018, p. 185.

7 Moser, 2018, p. 185.

8 Drijvers, 1996. Against Drijvers, Woods, 2001. Millar, 2009, has presented interesting, slightly later, evidence on bilingualism.

9 Amm. Marc. 14.7.5-6.

10 Translation Hamilton, 1986, pp. 86-87, slightly modified.

11 Drijvers, 1996.

12 Woods, 2001.

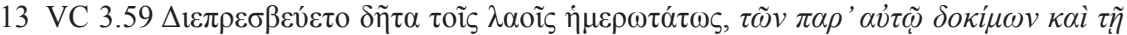

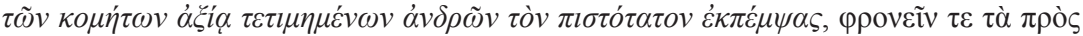

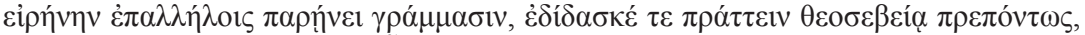

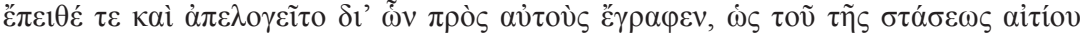

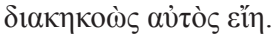

14 Amm. Marc. 18.5 - for example, "(Antoninus) utriusque linguae litteras sciens," where the author clearly means Greek and Latin.

15 Amm. Marc. 18.6.16, "Meiacarire nomine venissemus, cui fontes dedere vocabulum gelidi.” Kelly, 2008, pp. 116-117.

16 The other four times the term superstitio appears in Ammianus's history: 18.4.1 to describe the barbarous divination that Sapor employed; 21.16.18 to describe Constantius's "old womanish" superstition that caused all the theological division (Christianam religionem absolutam et simplicem anili superstitione confundens, in qua scrutanda perplexius quam componenda grauius excitauit discidia plurima); 25.4.17 to concede Julian's superficial observance of pagan ritual; 31.2.11 to describe the Hunnic religion.

17 For a list of "minority religions" in Persia, see, for instance, this inscription (discussed in Chapter 6) from the late-3rd century in which the Persian magus Kartir lists those he has supposedly exterminated from the empire: "The teachings of Ahriman and the demons disappeared from the empire and were made unworthy of faith. And the Jews and the Shramanas and Brahmins (Buddhists and Hindus) and the Nasoreans and Christians and the Muktiks ("purifiers," Judaeo-Christian Baptists) and the Zandiks ("heretics," Manichaeans) were driven from the empire and their idols were destroyed and the nests of demons were scattered which now have become the places and dwellings for the gods." Translation adapted from Gignout, 1991.

18 Epipanius Panarion 3.13-17 (Holl, 1933) discusses Mani's background in Red Sea trade and the penetration of his religion into the Eastern Roman Empire.

19 Athanasius Hist. Ar. 15.3.

20 In this section, I am following closely to Scholten, 1998.

21 Libanius, Epistle 430.6-7, my translation.

22 One of the main themes of Libanius's correspondence. See, for instance, the unlikely letter to Barbatio, Bradbury, 2004, pp. 58-60. Jovianus was killed for his ambition to become emperor, PLRE 1.460-461, Ammianus 25.8.14.

23 Bradbury, 2004, p. 20, Foerster, 1927, 1.400-405. Bradbury, 2004, dates these letters to spring 356. Libanius's relations with Strategius are no better in the summer of 356 when he writes to a former student, Bradbury, 2004, pp. 57-58.

24 Themistius Oration 4.57b.

25 Themistius and Libanius may be poking a little fun at Shapur when they refer to his realm as that of the Achaemenids.

26 Amm. Marc. 17.5.12: praefectus praetorio meus opinatus adgredi negotium publicae utilitati conducens cum duce tuo per quosdam ignobiles, me inconsulto, sermones conseruit super pace. non refutamus hanc nec repellimus: adsit modo cum decore et honestate nihil pudori nostro praereptura vel maiestati. 
27 If this letter is not refering to Clematius, then there were even more agents unknown to us traveling across the border into Persia at Constantius's orders.

28 Marcos, 2012, pp. 507-510. Contra Seager, 2010.

29 Scholten, 1998.

30 Agentes in rebus, in their mature form in the 5th century, were under the direct authority

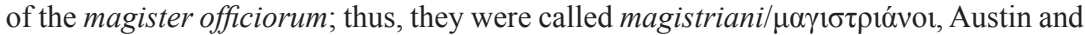
Rankov, 1995, pp. 218-220, Boulenger, 1618, p. 590. But throughout the discussion of our agents who were active in the 350 s, there is no mention in all the sources of orders from a magister officiorum. See further discussion below.

31 Austin and Rankov, 1995, p. 221. Giardina, 1977, pp. 103ff. includes a prosopography of the agents and arguments against the traditional interpretation of functions.

32 For example, W. Blum, 1969.

33 Sinnegan, 1959, for "secret police."

34 The original scholarly source on agentes in rebus is Boulenger, 1618, IV.42. Most contemporary scholars recognize O. Hirschfeld and R. Helm as pioneers in this study.

35 From the beginning of scholarship on agentes in rebus, observers noted that Constantine first mentioned them in an edict of 319, CTH 6.35.3 - for example, Arias Bonet, 1957, p. 198. Austin and Rankov, 1995, p. 219, believe that Diocletian most likely set up the agentes as a replacement for the frumentarii as couriers, following a long tradition - for example, Hirschfeld, 1893, p. 422. Dvornik, 1974, offers an accessible introduction to this topic.

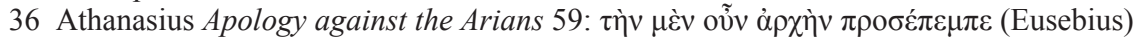

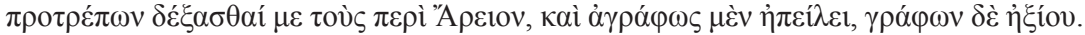

37 The latest edition, Hansen, 2002, persuasively argues that the author was not Gelasius of Cyzicus and that this anonymous author wrote around 480. After a long quota-

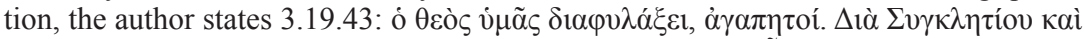

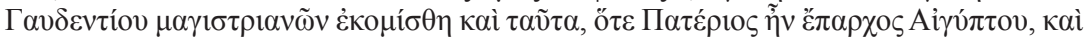

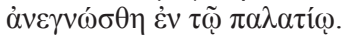

38 The first datable use of the Greek term $\mu \alpha \gamma 1 \sigma \tau \rho$ ióvos comes from an inscription dated to the reign of Honorius and Arcadius, IG XIV 949a, Paschoud, 1983, p. 235, and Giardina, 1977, p. 127. Athanasius, writing around 357, does transliterate the Latin term into Greek for two agents we know very little about, Apology to Constantius 10.15-22. It has been asserted that all agentes in rebus were palatini, PLRE 1.661, Palladius 16. Though Boulenger, 1618, p. 589, notes the two could overlap, he cites the Codex Theodosianus to demonstrate that they could be distinguished also, Boulenger, 1618, p. 590.

39 Athanasius History of the Arians 51, PLRE 1.658, Giardina, 1977, p. 103.

40 PLRE 1.460-461. Amm. 25.8.14.

41 PLRE 1.262; Libanius Oration 42.24-25; Amm. Marc. 14.7.9ff.

42 Amm. Marc. 14.11.9.

43 PLRE 1.146-147.

44 Austin and Rankov, 1995, p. 220.

45 Amm. Marc. 17.5.15-16.

46 CTh 6.29.1-5.

47 Athanasius Apology against the Arians 73.

48 An important point, outside the scope of this book, reflects the unstable identities of state officials and clerics. Not a few bishops were formerly agentes in rebus - for instance, Augustine's close friend Evodius, Confessions 9.8.17, Jerphagnon, 2003, p. 168.

49 Zosimus New History 2.53.

50 Purpura, 1973, and Paschoud, 1983, support this point with a good deal of detail.

51 There is no denying an overall expansion. For instance, CTh 6.29.23 is often cited to show that there were 1,174 agents listed in 430. Given Constantius's many edicts directed to the agents, it seems probable that he was responsible for the first expansion 
(as Julian was responsible for the first major contraction at the Commission of Chalcedon in 361).

52 Amm. Marc. 16.5.11, “et imperator 'rapere' inquit 'non accipere sciunt agentes in rebus'."

53 Amm. Marc. 22.3.2-3: causas vehementius aequo bonoque spectaverunt praeter paucas, in quibus veritas reos nocentissimos offerebat. 3. et Palladium primum ex magistro officiorum in Brittannos exterminarunt suspicione tenus insimulatum quaedam in Gallum conposuisse apud Constantium, dum sub eodem Caesare officiorum esset magister.

54 Chapter 2 provides the detailed analysis of the travel.

55 As noted in Chapter 2, Theophilus's loyalty to the Caesar Gallus, according to Philostorgius HE 4.1, cost him exile in 354. Perhaps in parallel to the exile of Eudoxius in 359 preceding elevation to the bishopric of Constantinople (Chapter 3), Theophilus's unusual expertise in all matters Red Sea overcame Constantius's anger . The mystery of Theophilus's career, however, remains unsolved.

56 Mommsen, 1905, vol. 1.2, p. 726, and Barnes, 1993, p. 120.

57 Mommsen, 1905, vol. 2, p. 726.

58 A third issue with this edict is presented in Becker, 2015, p. 107, who points out perceptively that the use of gens with genitive plurals (Axumitarum, Homeritarum) is unique in the Codex Theodosianus. Becker explains that it has to do with the special trading status of eastern kingdoms close to Persian influence.

59 A traditional Egyptian calendar designed for tax purposes. The details of epochal dates, changes, and reforms run into deep discussions, Luisier, 2007, and Thomas, 1978. My quite inexpert sense is that Mommsen's indiction dating is in a time range that experts agree upon.

60 Haas, 1996, passim, but esp. pp. 282-294, argues that the Athanasian faction had congregated in the central areas of Alexandria, thus controlling the financial and trading centers, while Arians and pagans had migrated to the suburbs. Sozomen HE 4.10 tells a story of Athanasius pretending to sail up the Nile and then sneaking past his pursuers downriver and back to Alexandria where he remained hidden. Socrates HE 2.28 and Theodoret HE 2.11 appear to mimic Athanasius's own account (Apology for His Flight 6-8) of George's Arian persecution, none of which supports or negates Haas's contention.

61 Lenski, 2004, argues convincingly that Valens waited till Athanasius's death in 373 before even attempting to discipline the monks. This indicates at once both the power and prestige of Athanasius and also the monks' fierce loyalty, especially in Egypt. Valens cleverly moved to break up the monasteries by conscripting the monks into the army and treated conscientious objectors as deserters by pummeling them to death. Ghica, 2012, esp. on pp. 194-195, working from archaeological evidence explains the dynamic of the Athanasians in Egypt, west of the Nile.

62 See CTh 6.29.2.4 or CTh 6.29.5 for explicit evidence that this avarice and corruption was becoming common at least in the western part of Africa, but the new emphasis on curiosi in all provinces supports the likelihood of patronage schemes elsewhere that the emperor wanted disbanded.

63 There are only three other edicts in the Codex Theodosianus that limit delay: CTh 6.33.1 that limits the duration of the office of chief of imperial guards to two years; CTh 8.5.1 that one must delay one's trip for an available ox at the station rather than taking one from a neighboring ploughman; and CTh 8.8.9 that (under Honorius and Theodosius) financial officers sent out to exact a claim must return and report their function within one year.

64 See CTh 6.29.2.4 or CTh 6.29.5 for explicit evidence that this avarice and corruption was becoming common at least in the western part of Africa. Constantius addressed the latter edict to all agentes in rebus in 359 shortly after our episode (cesset omnis ambitio atque suffragium in schola vestra). 
65 Cottier, 2010, surveys the traditional duties and taxes. In addition to the 25 percent

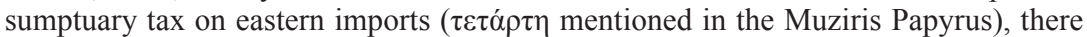

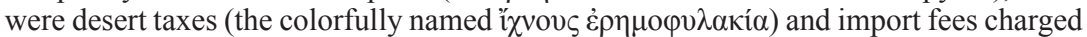
at the canal into Alexandria, Bogaert, 2000, p. 201.

66 Interesting comparative material suggesting the traditional background of statesponsored trade routes can be found in Isidore of Charax's Stathmoi Parthikoi. The gathered fragments make clear that the Parthians made considerable efforts toward building stations along suggested trade routes both for the caravan's convenience and for steering trade through the various custom stations built along the routes. Isidore's work has been recently and impressively treated by Hartmann, 2017.

67 Libanius Oration 1.115-116, PLRE 1.423.

68 Libanius, Ep. 331.

69 Russell, 2000, p. 10, on Theophilus's building program. Also Haas, 1996, pp. 206-214.

70 Trimingham, 1978, and Bowersock, 1980.

71 Discussed in Chapter 9.

1 Kelly, 1995, is the most useful biography for John's missionary tendencies. Allen and Mayer, 2000, gives an excellent, accessible biography and several translated letters pertinent to John's relations with the Goths.

2 Lenski, 1995, pp. 77-79, argues that there was deliberate Roman evangelization in Gothic territory in the 4th century, though it does not appear to have any diplomatic intent. Lenski concludes that "encouragement rather than active sponsorship seems to have characterized imperial attitudes to the process of Christianization beyond the borders," p. 80. He nevertheless goes on to discuss Valens's efforts to influence bishop selection in Arabia and Armenia as well as briefly mention Constantius's efforts in the Red Sea.

3 Recent work has made a powerful case against a deeply entrenched and dominant 4th-century Arian controversy: Gwynn, 2007, Gwynn, 2010, and Ward-Perkins, 2010. Nigro, 2012, opens a discussion of peaceful Gothic-Roman interaction that we will take up at the end of this book.

4 This is not to say that there never was, and still is not, a substantive discussion over how Jesus the Son is subordinated to God the Father, from the Cappadocians all the way to myriad contemporary theologians, with a rough divide between those who favor refined philosophical language and those who prefer simple biblical language.

5 Athanasius, with significant justification, continued to suspect that the Homoian creed was a mechanism to allow for heretical subordinationists to carry on as they preferred.

6 Expression of this disgust would climax with the Constantinople riot in 400, but it is worthwhile to look at the argument emphasizing aspects of Rome's beneficence toward Goths: Girardi, 2012.

7 This is not to say that some form of "Arianism" did not dwell in the self-identification of Goths, as is clear in recent work - for example, Cosentino, 2016.

8 For instance, at the Council of Serdica 343, Athanasius and allies unanimously voted to banish a long list of eastern bishops (Theodoret HE 2.8). Athanasius summoned his own council in 346 in Alexandria to confirm these banishments.

9 Theodoret HE 5.30-31.

10 The Goths have enjoyed a good deal of scholarly attention, almost all of which is contained in the bibliography of the excellent unpublished dissertation by Jonathan Stanfill (2015). Essential reading would include Thomson, 1966, Wolfram, 1988, Albert, 1984, Heather, 1991, and Lenski, 1995. For mission specifically, Sibiescu, 1973.

11 CTh 16.5.6. Stanfill, 2015, p. 201, n. 215, gathers the various edicts leading to the banishment of Arians from Constantinople: CTh. 16.5.8 (July 19, 381); CTh. 16.1.3 (July 30, 381); CTh. 16.5.11 (July 25, 383); CTh. 16.5.12 (December 3, 383); CTh. 16.5.13 (January 21, 384).

12 Sozomen HE 8.4. 
13 Battifol, 1899.

14 Sokrates HE 6.6.

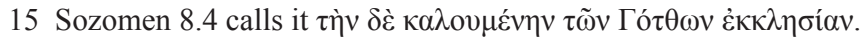

16 Here I am trusting Father Battifol's Greek-language instincts. I do note that John Chrys-

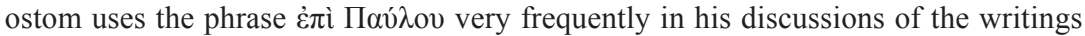
of Paul of Tarsus, thus, in a very different context, "according to Paul." As Battifol surmises, the editor who added the headings knew Chrysostom's style well and wanted to stay close to it. Nevertheless, the ė $\pi$ í with a genetive strikes me as odd here.

17 Albert, 1984, esp. Chapter 3 on John and Gainas, and Poguntke, 2016, esp. 252-259.

18 Sozomen HE 8.4 implies that the denial of his own city church began Gainas's rebellion. Theodoret's account provides dramatic dialogue but less historical context HE 5.32.

19 Laird, 2013, pp. 146-147.

20 Wulfila attended the Council of Constantinople in 360 and reportedly agreed to the "Homoian" creed promulgated there, according to his most sympathetic sources, Auxentius and Philostorgius. For text of Auxentius, Gryson, 1980, pp. 244-251, and for Philostorgius, Winkelmann, 1981.

21 Stanfill, 2015, has made a strong case for this, but it can be found in condensed form in Stanfill, 2013.

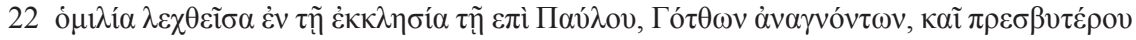

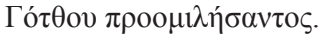

23 Theodoret particularly emphasizes John's single-minded crusade focused against the theological errors of the Goths, but this is not at all clear in any of John's writings or, as stated above, in an accurate historical understanding of Constantinople in the year 400 .

24 Schäferdiek, 2006, pp. 292-293, pushes in the direction of John's role in producing a Gothic identity in Crimea through his validation of the (Gothic) language of Wulfila's Bible translation at a time when the area was under Hunnic pressure.

25 Kelly, 1995.

26 Washburn, 2016.

27 John Chrysostom, Letters to Olympias 9.3.

28 Schäferdiek, 2006, asserts Crimea.

29 Stanfill, 2015, pp. 178-181, agrees on John's consistent plans in Gothia but adds a good deal of detail about the history of Chrysostom scholarship.

30 Barnes and Bevan, 2013, present an excellent translation with important commentary.

31 Barnes and Bevan, 2013, pp. 53-54.

32 Sozomen did show particular interest in Gothic conversion. For instance, Sivan, 1996, discusses Sozomen's particularly glowing and lengthy account of Wulfila's life and conversion of the Goths, HE 4.24 (meeting with Arians), 6.37 (conversion of Goths and of self), 7.17 (the tradition of preaching in Gothic language).

33 van Nuffelen, 2013.

34 W. Mayer, 2018a, expands on van Nuffelen's discussion into cognitive/linguistic readings of the two camps.

35 The role of the new bishop Proklos and the Roman bishop Innocentius I are often discussed, Kelly, 1995, pp. 288-290.

36 Mayer, 2004, presents a fascinating argument that John had formed a good deal of his agenda and even minutiae of behavior as he was groomed for the episcopate under Flavian in Antioch. From this perspective, the tendency toward "internationalism" we have seen in Flavian's bishop partner, Diodore of Tarsus, becomes even more significant. A hint at this can be seen in a simple category made by John like his dividing local choruses into three categories, Roman, Syriac, and barbarian, PG 63.472. Mayer, 2011, p. $92 \mathrm{n}$. 32, points out two homilies intended for Syriac audiences Cat. 8 (SC 50bis, 247-60), De statuis hom. 19 (PG 49.187-98). This discussion is expanded in Chapter 6. 
37 Barry, 2016, expounds an interesting interpretation of Eudoxia's and John's sicknesses/ deaths.

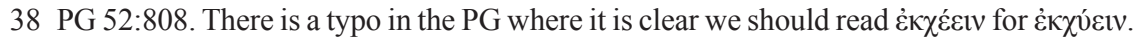

39 Voicu, 2002.

40 The Council of Constantinople in 381 created two canons of interest to our discussion. The 2nd canon ruled that bishops should not interfere in business outside their diocese and that barbarians (presumably Christians of non-Greco-Roman language and liturgy who were living outside the imperial boundaries) should follow their ancestral customs. As discussed below, John felt comfortable flaunting the first canon as he ordained bishops throughout Asia in 402, and for the second, we can assume that he understood the barbarians to be open to evangelization by any bishop. The argument has also been made that John interpreted the 3rd canon in which the bishop of Constantinople was elevated to equal honor with the bishop of Rome, to mean he was free to interfere wherever he wanted. See Stanfill, 2015, pp. 51-56.

41 Mayer, 2004, justly warns us that John's training as bishop and thinking on how to rule as bishop have roots in his Antioch days. The earliest potential clue as to his missionary thinking, I have found, was proclaimed in his sermons against the Anomaeans, preached in 386 or perhaps 387, de incomprehensibili dei natura 2.255-268, Malingrey et al., 1970.

42 Sokrates HE 6.19.

43 Sozomen HE 8.6.

44 Sozomen HE 8.6.6. Kelly, 1995, p. 178.

45 Wenger, 1952, brings to light a fragment of a sermon by John, which he interprets for the baptism of Theodosius II on Epiphany, January 7, 402. As Kelly, 1995, pp. 172-173, argues, after performing this necessary act as bishop of the capital, John must have immediately sailed for Ephesus.

46 Kelly, 1995, p. 144, stated, “John's great interest in promoting Christianity among barbarians and outside the borders of the empire was at this time unusual, not to say unprecedented."

47 The Cappadocian Fathers' relations to the Goths were, of course, more complex, Zuckerman, 1991. But there is no evidence that they were moved to send missions.

48 Heather, 1991, pp. 181-192 provides a detailed narrative of the "general racial tension" between Goths and Romans in the two decades before John's ascension to the see of Constantinople.

49 Juvenal, the bishop of Jerusalem in the early 5th century, did assign a native Arab sheikh as bishop of the "Arabs of the encampments," but this appears to be more a reaction to an opportunity than part of an active campaign. See more on this in Chapter 7.

50 S. Ivanov, 2003, p. 65.

51 Matthew 28.

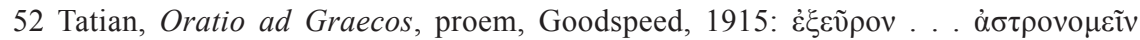

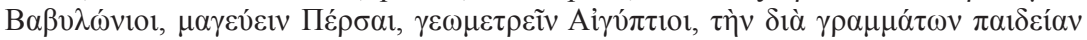
Фоíviкes.

53 Kalleres, 2005.

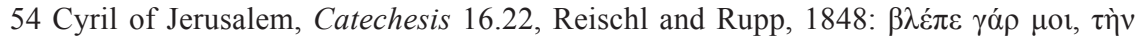

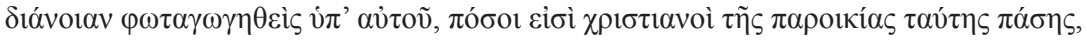

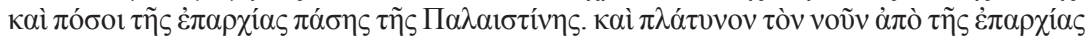

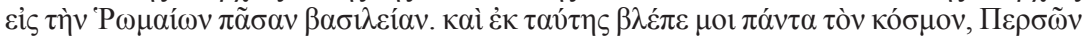

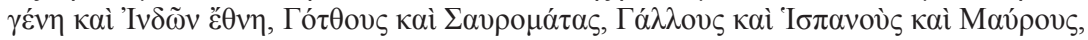

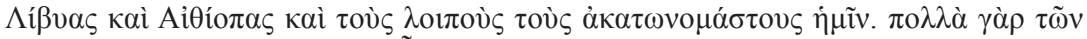

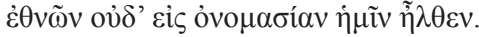

55 It will be no surprise that Athanasius, in his conflict with Constantius, may be the one responsible for reviving Tatian's rhetorical trope. 
56 John Chrysostom, De incomprehensibili dei Natura, homily 2, 11. 262, Malingrey et al.,

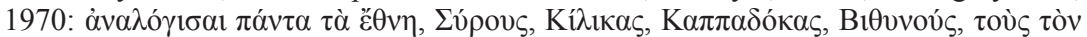

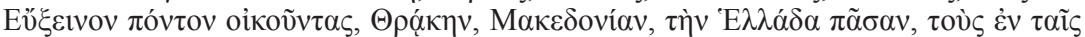

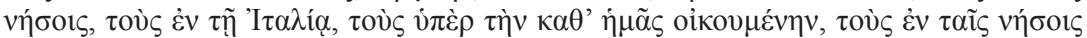

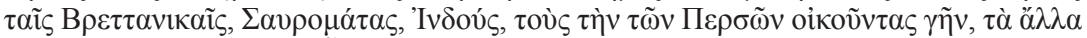

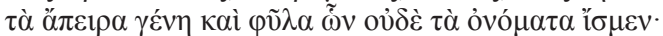

57 Theodoret emphasizes Diodore's influence on John in an interesting passage about Theodore of Mopsuestia, HE 5.39.

58 Readers of this book will not be surprised that Athanasius used the ethnic list as a "dissident" strategy also - for example, De Incarnatione Verbi 51.2.

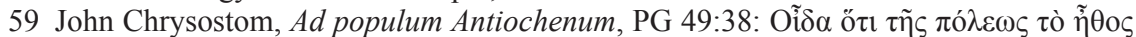

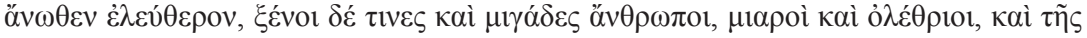

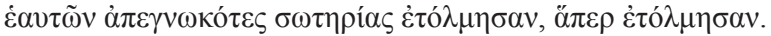

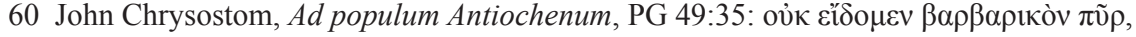

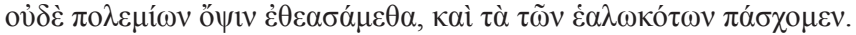

61 This point will be expanded in Chapter 6 .

62 John Chrysostom, Homilia habita postquam presbyter Gothus concionatus fuerat, PG

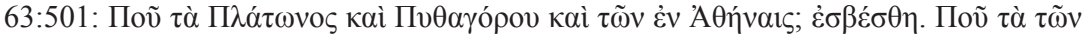

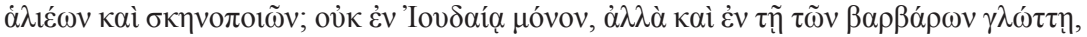

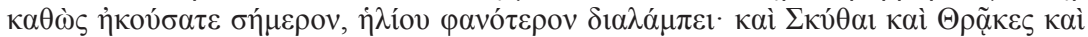

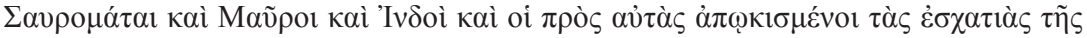

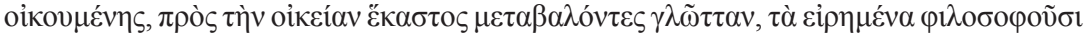
$\tau \alpha \tilde{\tau} \tau \cdot$. John returns to this trope elsewhere, most especially in his homilies on the Gospel of Matthew - for example, PG 57:18 and PG 57:392.

63 Dolezal, 2006, provocatively argues that John's movement with the Goths became policy several years later for Theodosius II, a position that might imply Eudoxia's support.

64 HE 11.6.

65 Stanfill, 2015, pp. 184-198, does a magisterial job of cataloging all the scholarly lore on the monastery of Promotus.

66 Mayer, 1999, fleshes out the importance of aristocrats forming female monasteries out of their households. For instance, Olympias appears to have upward of 250 members in hers when she leaves Constantinople. But this monastic formation should not be confused with a 2nd-language, male, ethnic monastery, which would be very unlikely for someone like Marsa to form in her house.

67 Note also that there are those, with good reason (i.e., Palladius's witness Life of John 4), who see Marsa as one of John's most effective enemies - for example, Delgado Jara, 2003.

68 Numismatic evidence argues that Eudoxia communicated a position of enormous power to the point that Honorius was alarmed in the western empire, Gambacorta, 2011.

69 A strong hint towards Eudoxia's interest in extra-Roman Christianity is found in John's sermon delivered to her upon translating relics of martyrs, PG 63.467-472, where he claims that the empress has sponsored choruses in many languages. Mayer, 2018b, persuasively undermines the traditional narrative that John and Eudoxia became enemies because of his criticisms.

70 Walafrid Strabo does mention a Gothic liturgy in the 9th century. See discussion in Green, 2008, p. 409.

1 For the literature left in Marouta's name, see Vööbus, 1982, pp. 439-440, and Brock, 1982b. See also Fiey, 1976; Marcus, 1932; Noret, 1973.

2 Sozomen HE 8.16.

3 Cyrinus, among the most openly hostile enemies of John, was wounded inadvertently by Marouta during a meeting in the victim's see, Chalcedon (Sokrates, HE 6.15). The wound apparently festered for several years and, after a series of amputations, caused his death, not before he was able to contribute to John's final exile. Sozomen (HE 8.16) 
compresses the period of suffering while also emphasizing Cyrinus's close relation to Theophilus, the bishop of Alexandria. It's reasonable to suspect that the story of Cyrinus's death by Marouta's accident came to these historians as part of Johnite propaganda that was intended to demonstrate God's vengeance against Cyrinus. Presumably Marouta, though he voted against John in 403, had become a Johnite hero by 410.

4 Briquel-Chatonnet, 2010, p. 179. Jullien, 2006, vol. 1, pp. 163-165, demonstrates Marouta's fundamental role in developing monastic rules in Sasanian lands.

5 Malingrey, 1968, Epistles 9.5.

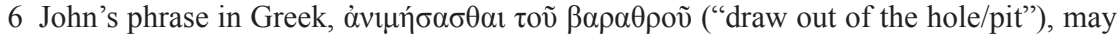
imply something different by its imagery. The verb suggests drawing water from a well - a possible metaphor for enticing Syriac ascetics who found solitude in cisterns or wells back into the world of affairs. For instance, see below our discussion of Macedonius, the Syriac holy man, whom Theodoret describes as spending a good deal of time in a cistern.

7 Sako, 1986, pp. 62-70, presents an embassy in 399 in addition to the one we will discuss in 410. Though he relies solely on al-Tabari as a source, his chronology fits well with my projected relations between Marouta and John.

8 There is some evidence that the see of Antioch also supported Marouta's work in Persia, S. Gero, 1981, p. 22. If we are to credit this evidence, then it would only support John's role due to his tight relations with Antioch. In addition Gero, 1981, p. 24, points out the prominence of the writings of John's teacher Diodore of Tarsus in the early Persian churches' Syriac exegetical tradition.

9 For a translation of the many testimonia regarding Marouta in Persia, see Vööbus, 1982, pp. 439-440. In these texts, a Syriac hagiographical tradition witnesses Marouta miraculously and widely evangelizing within the Persian realm. Brock, 1995, pp. 29-30, discusses details of Marouta's role and its context.

10 My translation of the French from Garsoian, 1999, p. 54. Chabot, 1902, pp. 256-257. For a concise survey of the history surrounding the Synod of 410, see Erhart, 2001.

11 McDonough, 2008, inspects various narrative threads on Yazdgard's career in more depth than I can here. Berti, 2013, p. 858, points to Marouta as an "imperial messenger" (messo imperiale) at the Council of Seleuceia in 410 and makes a case that this council began a fundamental change in Syriac Christianity. It is argued below that the nine-yearold Theodosius was unlikely to send Marouta to Seleucia, and the potential role of his regent Anthemius is opaque enough that John's influence could still be at work. As we just saw, the Acts of the Council specify that Yazdgard insisted on Marouta's participation in organizing the council. The new generation of Syriac specialists appears to take it for granted that Theodosius II instigated this church formation, Smith, 2012, p. 17.

12 It is clear that most of the canons of the Synod of 410 were ignored, Brock, 1995, p. 31, though the evidence has been read by specialists to support my reading - for example, Briquel-Chatonnet, 2010, p. 179.

13 Garsoian, 1999, p. 293.

14 The (mostly "secular") internal politics of Persia at this time are treated in great depth in the provocative book by Pourshariati, 2009, specifically discussing Yazdgard I and his son Bahram, pp. 59-70. Her view that Parthian factions simmered under the pretenses of a centralized Sasanian state opens up new ways to understand relations with the Romans in this period, but these extend beyond the scope of this study.

15 The date of 412 is taken from the context of Sokrates' narrative (Cyril's accession as bishop of Alexandria) and should not be taken as firm. It may well be that Sokrates' chronology is confused, and the story refers to Marouta's journey to establish a Sasanian church at the Synod of 410.

16 Sokrates, HE 7.8.

17 Theodoret, Historia Religiosa 8, Canivet and Leroy-Molinghen, 1977, indicate Anthemius's experience in eastern matters. 
18 Theodoret, HE 5.38.

19 To confuse this story further, Sokrates HE 7.8 tells us that Marouta and Abdas teamed up to combine the power of their fasting and prayer in casting out Yazdgard's son's demons. Sokrates tells us that the shah himself was so impressed he was on the verge of converting to Christianity when he died (420). Obviously, this story cannot harmonize easily with Theodoret's quoted above that Yazdgard had Abdas killed. And the likelihood that the son was Bahram, Yazdgard's successor, makes the matter even more confusing. Most traditional Christian churches (that celebrate martyrdoms) celebrate the martyrdom of Abdas (sometimes Audas), as bishop of Susa, on March 31 along with his deacon, Benjamin.

20 See discussion of Sasanian policy and Roman reaction below.

21 For instance, Cyril of Scythopolis's discussion of Aspebetos and his Arab tribe's migration, Life of Euthymius 18.22, Schwartz, 1939. See also Shahid, 1989, pp. 40-49.

22 Sokrates, HE 7.18.

23 Holum, 1982, p. $97 \mathrm{ff}$.

24 See Holum, 1977, on chronology.

25 Greatrex, 1993, dates the war to 420.

26 Some contemporary specialists will take issue with the term "state religion" - for example, Alram, 2008, p. 19, "The new type of coin chosen by Ardeshir emphasizes the special role that Mazdaism was to play in the Sasanian state from this time on. This does not mean, however, that Ardeshir elevated Mazdaism to a kind of 'state religion.' It is more likely that his main desire was to assert the king's absolute claim to power with regard to the Zoroastrian priests and to see his political course legitimized by religion." For our purposes, the last sentence defines a state religion, in stunning contrast to the usage of contemporary Arsacid and Roman rulers.

27 Howard-Johnston, 2008, presents a compressed and judicious summary of the Sasanian state in late antiquity. See also Daryaee, 2008, for a surprisingly detailed short narrative.

28 Chaumont, 1988, pp. 55-56: "Les mages en étaient encore à la première phase de leur organisation en corps constitué, organisation qui en fera, avant la fin du $\mathrm{III}^{\mathrm{e}}$ siècle, un État dans l'État."

29 Though a moderately developed literature exists on the fate of Christians and Zoroastrians in the Sasanid Empire, I have found very little dealing with the political strategies behind Sasanian religious policy. Shaked, 2008, ought to be read against my arguments below. Wiesehöfer, 1993, also argues against Zoroastrianism as a state religion, at least in the 3rd and 4th centuries, though his points strike me as more of a corrective against the sins of historiographical Orientalism than convincing proof there was not a strong connection between shah and mobad. Decret, 1979, is a pioneering work that is essential reading for my topic, though he deals only with the late-3rd to late-4th centuries in detail. Decret's thesis, that the ebb and flow of persecution in both empires is based on imperial conflicts and strategies explains the 3rd-century evidence well but, in my opinion, begins to lose its power by the time of Yazdgard II. Brock, 1982a, provides another essential perspective for my study. Brock follows Decret but refines the thesis to periods of war between the empires and extends the scope through 6th-century examples. Payne and Soroush, 2014, also offers interesting and provocative theses, though mostly aimed at later period of Sasanian history.

30 Edwell, 2013, provides a compressed history of military and political interactions between Sasanid shahs and Roman emperors. Canepa, 2009, especially the introduction, should be read for context.

31 A focused introduction to 3rd-century Sasanian history can be found in Gagé and Walter, 1964, which includes a collection of source materials.

32 Abka'i-Khavari, 2000, provides, along with an exhaustive catalog of royal iconography, an introduction to the development of Sasanid conceptions of kingship. 
33 Translated from quotation in Widengren, 1968, p. 274. For a full English translation, Kawerau and Kroll, 1985.

34 Gignoux, 1991, p. 24, gives a terminus ante quem of 293, when Narses, who was hostile to Kartir's patron, Bahram II, took power, and Kartir is mentioned on his Paikuli inscription. It is clear that Kartir's activities took place in the 20 years or so before the publication of this inscription. See Frye, 1983, p. 128, and Widengren, 1968, p. 305.

35 Translated from quotation in Widengren, 1968, p. 306. See also Brock, 1995, p. 27.

36 Chaumont, 1988, p. 56, et passim.

37 Chaumont, 1964, is a good place to start. Russell, 1987, p. 121, states it more strongly: "In ca. 226, Ardeshir defeated his Parthian overlords and set about a radical reformation of Iranian life. Throne and altar had never been entirely separate under Arsacid rule - Tiridates I of Armenia impressed the Romans as both monarch and Magus - but Ardeshir transformed the Zoroastrian Church into a militant, highly centralized bureaucracy at the service of a similarly centralized state." Russell, 1987, cites Frye, 1956.

38 My translation of the French of Gignoux, 1991, p. 71, 1.14-5.

39 Frye, 1983, p. 128. Decret, 1979, p. 127, states the following on the relations between Kartir and Bahram II: "Ces investitures des plus hautes charges ecclésiastiques, qui conféraient au bénéficiaire le rang et la dignité d'un 'Grand' du royaume, sont assez révélatrices de l'ascendant de l' 'archimage' sur l'esprit du souverain." The point is also made that Bahram's military losses played a role in the new focus on centralized Mazdaism and rejection of minority religions.

40 Russell, 1987, p. 123, sees internal Zoroastrian missions beginning with Ardeshir, though the first hard evidence comes from Shapur I: "There seems little doubt that the missionary activities in Armenia ascribed by Xorenaci to Ardeshir: the establishment of ormzdakan and vramakan fires and the destruction of image-shrines were in fact undertaken by Shapur I, his son."

41 Canepa, 2009, p. 49, incisively sums up the complexity of the Sasanian relation to Achaemenid "ancestors."

42 For more detail, see Brown, 1969, and Honigmann and Maricq, 1953, pp. 21-38.

43 Widengren, 1968, p. 275: "Shapurh a accordé au manichéisme une place tout aussi grande qu'au zoroastrisme, bien que, reconnaissons-le, la politique religieuse qu'il a pratiquée dans les pays conquis prouve que ses preferences allaient au second." Chaumont, 1988, p. 107, et passim, seems to disagree with Widengren, suggesting that Manichaeism had infiltrated all classes and regions of traditional Zoroastrian loyalty. Decret, 1979, p. 127, quotes the Chronicle of Seert to demonstrate how conflation of Manichaeism with Christianity led to confusion and harsh persecution of each sect at times. The chronicle proposes that the shahs were concerned with Manichaean asceticism and declining birth rates.

44 Manichaean relations with the Jews were also problematic, Neusner, 1970.

45 Widengren, 1968, p. 305. Decret, 1979, p. 129, concludes that, under Bahram II and his "archimage" Kartir, "cette politique religieuse était d'imposer le mazdéisme comme religion unique à l'ensemble des populations."

46 Chaumont, 1988, p. 112; Widengren, 1968, p. 307.

47 See Neusner, 1970.

48 Brock, 1975. Christianity may well have entered Parthian Mesopotamia centuries before our study. See Harrak, 2005, which contains a translation of an important Syriac and Arabic text along with useful historical discussion of early Christianization in the introduction.

49 Widengren, 1968, p. 308. Chaumont, 1988, p. 112: "Il est visible que Kartir avait résolu d'éliminer tout ce qui était susceptible de retarder, de près ou de loin, le triomphe de la religion officelle sur l'ensemble du territoire sassanide." Chaumont tentatively identifies the Shramanas with Buddhists. Lieu, 1986, p. 482, reasonably reads the Nasraye as native Syriac Christians, the Krestyane as deported Christians of Greek origin, possibly 
including Marcionites, the Muktiks as Judaeo-Christian baptists, and the Zandiks as Manichaeans.

50 Chaumont, 1988, pp. 102-103, mentions the account, found in the later Arabic chronicles, that Kartir took advantage of the young Bahram II to make his own ecclesiastical policy. But she soundly disregards the likelihood that Kartir's activities arose independent of the shah's knowledge or will.

51 Translation from Brock, 1995, p. 4.

52 Cited from Brock, 1995, p. 4.

53 Russell, 1987, pp. 128-129. For a full translation of this puzzling source, see Garsoian, 1989.

54 Russell, 1987, p. 126 suggests that in Armenia, conversion to Christianity was a political reaction to Persian oppression: "Armenia had suffered greatly already from Sasanian invasion and persecution, and it may have been feared that the country would be absorbed entirely into Persia, were Zoroastrianism allowed to remain as a potential instrument of control by a foreign priestly hierarchy."

55 Chapter 5 discussed John's enactment of the ethnic list trope.

56 Trombley, 1994, p. 105, emphasizes Flavian's "interest" from the perspective of traditional Romans: "It (Libanius Oration 30) expresses a deeply felt outrage at the methods used by the monks who had begun to penetrate the Syrian backlands in the years immediately after the death of Julian the Apostate in 363, but particularly during the patriarchate of Flavian of Antioch (381-404) who turned a blind eye to the extralegal methods used by the monks to disrupt sacrifices at religious festivals and pull down temples." We will see John try to extend a similar project in Gaza after Flavian's death below.

57 Contemporary Roman views of Syriac-speakers are difficult to ascertain. For instance, both Socrates and Sozomen comment negatively on Severian of Gabala (Sokrates HE 6.11, Sozomen HE 8.10), as they tell how his heavily accented homilies in Greek charmed the whole capital city. Sozomen even presents himself as expert enough in Syriac to appreciate the euphony of Ephrem (HE 3.16), stating that the Syriac eloquence emanating from Nisibis eclipsed even the greatest Greek writers. Feldtkeller, 1993, explores the early stages of Syriac Christian identity.

58 Yannoulatos, 1969.

59 Ancient imperial Christians' (and their Western modern progeny's) ignorance of Syriac Christianity began most emphatically with Eusebius, Brock, 1992. This lacuna impacts our study in ways too numerous and complex to delve into here.

60 PG 49:189. See discussion of Macedonius below.

61 In this homily, John, not surprisingly for us, follows his rhetoric of simple Christianity versus the sophistication of Greek philosophy. The sincere farmers of the Syrian countryside are formed to be wiser than all the great philosophers. His rhetoric for noble "barbarians" naturally falls into place when discussing Syriac-speakers.

62 Stanfill, 2015, pp. 37-41, expands on this topic. Laird, 2013, p. 146, adds some thoughts on how John's pedagogical/theological views made him receptive to Syriac-speakers.

63 Theodoret Historia Religiosa 26.11. Note this passage includes an ethnic list of real visitors to Simeon Stylites with an interesting addition, the Himyarites.

64 I consulted the excellent translation of Price, 1985, p. 103.

65 Gatier, 2014, provides a useful overview. Background on this discussion is found in these essential sources: Tchalenko, 1953; Liebeschuetz, 1976; Liebeschuetz, 1979; and Trombley, 1993-4. Mayer and Allen, 2012, present a succinct and judicious overview of the setting of Antioch as well as containing a wealth of insights into the Antiochene factions and their main characters. F. Trombley, 1994, p. 134, states: "The different varieties of evidence demonstrate conclusively that the period between about 365-425 was the crucible of religious transformation for the Syrian peasantry."

66 Millar, 2009.

67 Briquel-Chatonnet and Desreumaux, 2011. 
68 Itinerarium Egeriae 47.3-4, Marval, 1982, while discussing the Easter liturgy in Jerusalem, points out that the bishop preached in Greek with a simultaneous Syriac translation, and that readings were done in both languages. The author adds that even monolingual Latin-speakers could be accommodated by various brothers and sisters assigned as translators. This multilingualism seems to be aimed at the many pilgrims from the east and few from the west. Cyril, friend and ally of Diodore and Flavian, was the bishop of Jerusalem at the time and technically under the canonical jurisdiction of Antioch. Corbier, 2008, provides a stimulating overview of relations among languages in the Roman Empire.

69 Diodore continues to be read as an intermediary between Syriac and Greek fathers - for instance, mediating Eusebius of Samosata for Basil of Caesarea, Van Rompay, 1992.

70 Flavian was ordained in 381 as the successor of Meletius, the previous bishop from whom modern scholars have coined the term Meletian-Nicene party. It is noteworthy that Theodoret underscores Flavian's ordaining Macedonius as priest, however unwilling the hermit was.

71 Mayer, 2004.

72 Van Dam, 1985; Ashkelony and Kofsky, 2004.

73 The 7th canon of the Council of Nicaea (325) vaguely gave the bishop of Jerusalem, John, at the time we are dealing with, special status under the authority of Antioch. It is telling in ecclesiastic politics that when this John of Jerusalem was attacked by Epiphanius for his purported Origenist leanings (394), it was Theophilus, bishop of nearby Alexandria, that came to his aid, though Flavian was still alive (Jerome, Letter to Pammachius against John, PL 23:355-396).

74 Sako, 1986, and Rubin, 1986, do an admirable job of setting the scene.

75 Obviously John's successor, Arsacius, was openly hostile. Sozoman HE 8.27 calls the next bishop, Atticus (406-425), an enemy of John but admits that he much later persuaded Alexandria to reinstate him on their diptychs to avoid a Johnite schism throughout eastern Christendom. Socrates HE 7.18 gives Atticus a vague diplomatic role in the war between Rome and Persia begun in 421, but that section of his history contains enough patent errors to bring much of the rest into question. It should also be noted that the Syriac tradition emphasizes Atticus's later kindnesses toward John, Brière, 1933, pp. 160-162. Atticus, however, was born in Armenia where an innate understanding of the tensions between Romans and Sasanians could be considered part of the culture.

76 Chapter 5.

1 Among many potential sources, two might be good launching points: Pohl, 2005, and Swain, 2016. An excellent caution can be found in Geary, 2018. Geary, 1999, provides an excellent review of the history of Gothic identity.

2 There was a general use of Greek with Latin steadily gaining, especially in North Africa and the western empire, but the majority of Roman figures we have met in this book were at least functionally bilingual. As for religion, Diocletian's repurposing of Philae expresses well the general ancient tendency to equate polytheistic gods across cultures - for example, Herodotus famously explaining how Greek gods originated in Egypt, Histories 2.50, or Isis is assumed into Greco-Roman cult with the attributes of Aphrodite/Venus in Apuleius's Metamorphosis.

3 Smith, 2011, while successfully countering the many excessive hints at Julian's Alexander complex, also underscores the influence that Julian felt, as had his predecessors and kinsmen Constantine and Constantius. There are those who have amplified Alexander's mission civilatrice, but consensus reigns that neither Alexander nor Julian (nor Constantius) held strong missionary inclinations.

4 Smith, 2016, pp. 72-73, points out the irony that Julian was more interested in conversion (cultural) than his Christian predecessors, Constantine and Constantius.

5 Zuckerman, 2013. 
6 Wood, 2012, p. 172, "If the late twentieth century saw the admission of the variety of Christian practice in Mesopotamia within the shared discourse and references of the Syriac literature of Ephrem and Aphrahat, one of the problems that awaits Syriac studies is to integrate this into the broader study of the culture and politics of the Roman, Persian, and Islamic worlds in Late Antiquity."

7 Griffith, 2009, p. 281, persuasively dates the text to the 420s. I will be following this important article closely in the next section.

8 Ammianus tells a lively tale that should caution us at 18.5. Antoninus, a high-ranking official serving under the governor of Mesopotamia, perceived that he was soon to be swindled in complicated tax dealings. He set about discovering important intelligence about Roman positions all over the empire; bought a house on the Tigris River; shared secrets with the Persian governor, Tamsapor, across the river; and then bundled up his whole family and possesions, crossed the river for good, and became a Persian. Roman identity could be shaken with fiscal injustice.

9 Griffith, 2009.

10 Dunn, 2015.

11 Edwell, 2017.

12 Howard, 1981, p. 75.

13 Griffith, 2009, p. 286.

14 Sozomen HE 5.3 insists that Julian neglected Nisibis for its partiality to Christianity, but the historian's own partiality may have led to overstatement.

15 Russell, 2005, does a heroic job of synthesizing fragmented sources on the cultural background of Nisibis in the 4th century.

16 Lieu, 1986, catalogs the deportations including those the Romans inflicted on Persian subjects. It should be noted, as Lieu documents, that Constantius also paraded Sasanian prisoners of war to a location in Thrace.

17 Debié, 2006, p. 139, states Jovian's deal was intended to save Nisibene Christians from Persian - that is, pagan - rule.

18 Lieu, 1986, p. 496.

19 Amm. Marc. 25.8.14: "Nevertheless, however much the unhappy people (of Nisibis) were tormented with great fear of the future, yet they could sustain themselves with one slight hope, namely, that the emperor would, of his own accord or prevailed upon by their entreaties, keep the city in its present condition, as the strongest bulwark of the Orient." Ammianus, who grew up in this region where he spent his formative years as a soldier, testifies frequently for the Roman loyalty of Syriac-speaking communities in the borderlands. His open ambivalence toward Christianity is equally apparent.

20 Lenski, 2002, p. 245.

21 Socrates HE 3.1 suggest Julian's intent was to create Christian dissension. See Sozomen HE 5.5. and Theodoret HE 3.2.

22 It should be noted that Nectarius before John, and his brother Arsacius, as well as the long-ruling Atticus, were all originally from the diocese of Antioch, though obviously promoted by factions inimical to the Meletians.

23 Griffith, 1986, p. 34, discusses this topic from the perspective of Ephrem who died in the early stages of Eudoxius's project. Seleznyov, 2010, esp. p. 186, surveys the eastSyrian Christian tradition conceding that there was significant anti-Byzantine feeling in that community.

24 Griffith, 1986.

25 Fiano, 2015, p. 97.

26 Fiano, 2015, pp. 92-101, treats Barses and the 360s in Edessa in impressive detail.

27 Griffith, 2009, pp. 288-289.

28 Debié, 2006, treats this episode in depth. 
29 It would be remiss to ignore another major source of Syrian Christian identity - that is, its unique liturgical expression. Harvey, 1999, presents a compelling and lyrical view of Ephrem's liturgical vision as a unifying force.

30 Garsoian, 1999.

31 Greenwood, 2012, p. 124: "He devised and was at pains to promote an exclusive Armenian Christian identity, one defined in opposition to an external Persian and Zoroastrian threat. Elise studiously avoided any discussion of doctrinal dissonance and portrays only faithful Armenian Christians and renegade apostates. This notion of Armenian identity equating to membership of the Armenian Church proved to be particularly potent in the following centuries." (Italics added for emphasis.)

32 Greenwood, 2012, p. 131, discusses Justinian's deliberate attempt to undermine Armenian unity in the 6th century.

33 Greenwood, 2012, p. 129.

34 Rapp, 2014, offers a novel and interesting insight into parallels for our nascent ethnic identities.

35 Scardigli, 2000.

36 Lenski, 1995, lays out the details from the sources clearly, though his contention that 4th-century Roman emperors took an interest in converting the Goths to Christianity was disputed in Chapter 1.

37 Chapter 5.

38 Zosimus 4.33, Ambrose Letters 24.8 (PL 17.1037).

39 Zosimus 4.53 .

40 A relatively favorable witness, Philostorgius, says, "There was no small amount of barbarian audacity in her" (

41 As seen above in Chapter 5, she was tutored by the learned Pansophios, whom, in cooperation with John, she elevated to the bishopric of Nicomedia against strong popular protest.

42 Details in Chapter 5.

43 Zosimus calls Bauto a Frank, and Ambrose calls him a transrhenus ("someone from across the Rhine River"). The linguistic status of the 4th-century Germanic peoples living east of the Rhine is not well discussed outside of technical historical linguistics. From the 4th century we have one Frankish inscription of doubtful provenance, the Bergakker Inscription, whose runes are similar to those of early Gothic inscriptions, Looijenga, 2003. Though certainly the dialect that Bauto spoke growing up would be different from that of the Goths, growing up at the same time in the Carpathians ("Old West Germanic" versus "Old East Germanic"), it is reasonable to guess not only that Bauto's native language was intelligible to Goths but that a Christian like Bauto living his life in armies populated by Goths was familiar with Wulfila's Bible and a Gothic liturgy.

44 Chapter 5 tells the story of John's "diplomatic mission" to Gainas across the Bosporus in 400 .

45 Chapter 5 explicated this episode in John's letters, reacting to the uniate bishop Ounila's death.

46 Liebeschuetz, 1992, p. 153.

47 Holum, 1977.

48 In this section, I am closely following the evidence gathered by Brock, 1982. Brock argues persuasively against any sense of national identity in the 4th century, though he concedes the special case of Armenia's distinct identity suddenly flowering in the 8th century. Of course, most of his points are directed at Christians living in Iranian lands, and most of these are drawn on Syriac sources. The lack of a distinct term in Syriac for a people defining itself in religious and political terms in and of itself does not seem to me to deny the early stages of politico-religious identification.

49 Smith, 2012, carefully reads two versions of the martyrdom of St. Simeon composed in Sasanian lands to show a more collective and militant view in the 4th century than the 
5th. Examples like these are essential for keeping us cautious in our generalizations on religion and political identity.

50 I am deliberately avoiding the great uncertainty surrounding Constantine's letter to Shapur. Frendo, 2001, draws upon interesting source material to cautiously defend its historicity in a diplomatic exchange around 325. As argued in Chapter 1, Constantine's interest in Christians abroad appears marginal at most.

51 Demonstration 5.1.24, translation taken from Brock, 1982, p. 8. As discussed in Chapter 1, I believe that Barnes, 1986, tries to put too much weight on the testimony of Aphrahat in concluding that Constantine overtly planned to save Sasanian Christians. Barnes, 1986, also argues that Constantine planned his Persian campaign "as the self-appointed liberator of Persian Christians." A more detailed discussion can be found in Sebastian Brock, 1995, pp. 27-28. See also the more recent refutation in Smith, 2012, who pours welcome caution onto the standard reading of this passage.

52 Decret, 1979, p. 142, cites Aphrahat Demonstration 23 in which Shapur II's order to destroy the churches arose from a suspicion that Christians all must be allied with Rome. As with the quotation above, whether or not Shapur's motive is historical, Aphrahat was at least able to conceive of such a motive, and presumably, his audience not only understood but even sympathized with the idea.

53 J. Walker, 2006, pp. 1-16, gives a good orientation on the scholarly complexities of studying this text and its companions.

54 Brock, 1982, p. 14.

55 In this section we are ignoring the Christian communities deported into Sasanian lands from the Roman Empire, since they had an obvious identity, at least at first. Jullien, 2006, covers the topic well and shares useful bibliography.

56 Fascinating insights into Christian life in Sasanid Iran continues to come to light; for instance, P. Gignoux, 2010, explores evidence of early education. Of special interest are Christian stories of parents sending children to a Mazdaist school and the children running away as an act of Christian opposition. Of more significance to a slighter later time than our interest is Payne, 2015, p. 62, though the point is made that Sasanian Christianity did cling to Syriac, as opposed to Persian language due to the latter's strong connection to Zoroastrianism.

57 Brock, 1995.

58 The Acta Archelai, a remarkable text, demonstrates the context of Christian-Manichean tensions on the border in the 4th century, Scopello, 2008.

59 That is, Roman and Christian identities as well as Sasanian and Zoroastrian identities would be caused to join at a relatively popular level. And such a melding might not only take place on both sides of the imperial boundaries but also more intensively among those caught in the cross fire, in many smaller border states.

60 My translation of Life of Euthymius 18.22. See also translation and notes by Festugière, 1962, pp. 71-72.

61 Shahid, 1989, pp. 40-49, argues that the event is historical and against Nöldeke, 1879, and Christensen, 1929, that Aspebetos was not only an Arab but the first Arab phylarch. Shahid, 1989, pp. 64-65, also discusses Amorkesos who appears to follow the example of Aspebetos under Peroz in 464.

62 See Socrates HE 7.18 and Theodoret HE 5.38 for examples. We have seen above that the shahs quickly arranged high priests for their new conquests, so it is not unreasonable to assume that they used client kingdoms in a similar way.

63 Life of Euthymius 25.9.

64 Trombley, 1994, pp. 166-170.

65 An extensive discussion on Christian identity within the Sasanian lands has led to fascinating results. For instance, Gyselen, 2006, in which important work on Christian seals by Shaul Shaked and Philippe Gignoux is reviewed and expanded upon. Problems of dating undermine the advantage of this fascinating form of evidence, but it is clear that 
Christians in the heart of the empire gradually adapted to hybrid identity. It is tempting to speculate on how iconography of crosses could have played out across the border in 5th-century history. The presence of what Gyselen calls "Latin" crosses could be significant, since this form first appeared in the coinage of Pulcheria shortly before our war and has been read to represent a "crusader" cross intended to inspire Christians against the Sassanid persecutions, Holum, 1977. Did these crosses originate in the Arab communities between empires and become a symbol in 420 ?

66 Fiey, 1974, provides a sweeping survey of the success of Christianity in Persian lands following the period of our study.

1 Bérenger, 2012, draws out, especially from the epigraphical record, the tradition of recognizing the inherent dangers of being a diplomat. Of course, the long but routine trip to Ctesiphon that Marouta made many times cannot be compared directly to Theophilus's risky expedition.

2 Helm, 1932. There is a profound literature explicating the hundreds of treaties in this period and the subtle changes in conception for diplomatic words like foedus and deditio. Isaac, 1990, Blockley, 1992, Chrysos, 1992, Chrysos, 1989, Whitby, 2008, and Delaplace, 2012, would be good places to start.

3 Blockley, 1992, pp. 5-6.

4 Ammianus 17.5, Themistius Oration 4.57b.

5 Ammianus 18.6.17-19, tells a curious tale of Procopius's detention and efforts to pass coded messages to the Roman troops. Nechaeva, 2012, esp. pp. 192-196.

6 Ammianus Marcellinus, History 27.5.1 and 27.5.9.

7 Ammianus Marcellinus, History 30.2, 31.1, Blockley, 1992, pp. 37-38.

8 Claudian, On the Consulship of Stilicho 1.51-68 and John Lydus, De Magistratibus Reipublicae Romanae 3.53. Battistoni, 2012, explores the long and proud tradition of orators as ambassadors.

9 Discussed in Chapter 5.

10 Treadgold, 2004, p. 714.

11 Antonopoulos, 1992, shares an excellent caution to this very game of apportioning success or failure to diplomatic ventures.

12 Lee, 2009, but also see Lee, 1993. Nechaeva, 2012, delves into secretive behavior, mostly in later periods, but with some interesting commentary on the curious coded message from Procopius (mentioned above with Lucillianus), reported by Ammianus in the first person (18.6.17-19).

13 Chauvot, 2012, explicates an interesting case of failed diplomacy, with special interest in Ammianus's concept of munera ("gifts"). When Valentinian took over, he reduced the recurrent gift value to the Alamanni, who then rebelled and ravaged Gaul (364). Though there was not a failed diplomatic mission, the ambiguity of the word munera, ranging from yearly treaty payment to diplomatic symbols of exchange to "gifts," should be kept in mind.

14 Anfray, 1970, p. 269, explains the fascinating intricacies of Aksumite chronology that are themselves significant. The Greek inscription translated for Chapter 2 followed an Alexandrian system of dating based on the Roman Julian calendar. Using this, scholars can date the inscription within the three cycles of years that give us 349, 355, and 360 . Two important points should be added. One, that Aksum and subsequent polities followed Coptic practice as Christians for millennia and received their bishop from Egypt consistently until 1951. That is, this Ethiopian kingdom's church retained loyalty to Alexandria/Egypt. Two, the Greek inscription appears to have been posted along with one in Geez that sent a far less aggressively Christian message to Aksumite citizens who presumably would not understand the Greek.

15 Philostorgius asserted that Constantius sent the mission to Christianize the Himyarites. In the unlikely case that this assertion was accurate, the mission was obviously a failure.

16 Synesios, Letter 95, Hercher, 1873. 
17 de Francisco Heredero, 2014, gives a vivid portrait of the multiple ethnic groups gathered to defend the borders of northern Libya. She adds persuasively that the letters of Synesios point to a stronger loyalty to homeland - in this case, the Pentapolis - than to the empire.

18 Synesios, Letter 122.

19 Synesios uses the word, $\pi \rho 0 v o \mu \varepsilon v ́ o v \tau \varepsilon \varsigma$, which means both "forage" and "plunder," perhaps in order to create a humorous double entendre.

$20 \mathrm{He}$ has the deacon attack an enemy hoplite (ó $\pi \lambda i \tau \eta v)$ with nothing but a stone, vanquish the hoplite, strip the dead enemy's armor in epic fashion, and then pile more victims on as the fighting ensued.

21 Becker and Drocourt, 2012, esp. pp. 1-9, Becker, 2014b, and Becker, 2015.

22 Dolet, 2010. The topic is better studied in classical antiquity, 1985, Stouder, 2012, with the latter including an excellent bibliographical survey. Eilers, 2009, is essential reading, both for the range of papers and the methodological insights. Special attention to Eck, 2009 , who probes deeply into issues of textual survival, the extant record, and possible distortions therefrom.

23 Lee, 1993, pp. 40-48.

24 Dag Hammersköld, Nobel Prize winner in 1961, could be raised as an example of successful professional diplomats in the 20th century.

25 Finkelstein, 2003.

26 He himself would have emphasized his basketball career at the University of California, Berkeley.

27 Dolet, 2010. Mathisen, 2012, asserts that class (or at least rank) was essential in late Roman choices of ambassadors.

28 Dolet, 2010.

29 Trania, 2012, asserts that Marouta was sent by the court to Yazdgard's Council of Seleucia in 410 and generalizes that the Romans used clergy as diplomats and Sasanids did not. Even more interesting, following the Armenian sources, Nersēs's envoy appears to be the first use of an Armenian cleric for diplomacy with Rome (358).

30 As noted in Chapters 2 and 4, Theophilus's career is shrouded in mystery, but it is most likely that he was ordained bishop before 354 when he became enmeshed in the downfall of the Caesar Gallus.

31 On the contrary, the 5th-century Armenian sources valorize the linguistic sophistication of their polyglot clerical diplomats like Narses and Mesrop, Trania, 2012, p. 204.

32 Stein, 2008, reopens the discussion as to whether or not the Himyarites spoke their own documented dialect of highland ancient South Arabic, and thus, on stone, they were aping the inscriptional language of their forebears' in hegemony, the Sabaeans. As distinct as the highland dialect may be, it is most likely that the merchant communities by the coast and the royal court were familiar with more generalized dialects that Theophilus probably spoke.

33 Tobi, 2013, includes a Greek-language inscription from a synagogue in Himyar.

34 From Nöldeke, 1879, to Pigulevskaia, 1951, scholarship of profound depth laid the groundwork, but Smith, 1954, provides an accessible introduction, especially to the rich epigraphical remains. Yule, 2007; Potts, 1990; Robin, 1980; M. Bâfaqîh, 1990.

35 Nechaeva, 2014, pp. 178-180, discusses the importance of horses as diplomatic gifts in Arabic sources.

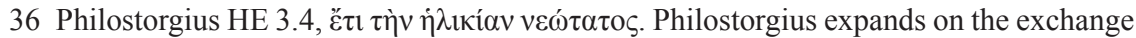
being in the time of Constantine. The passage does not imply that the emperor had anything to do with it, but we are still left to wonder what sort of deals were being made in the early 4th century in trade between Socotra and Rome.

37 Ammianus Marcellinus 17.5.2 mentions that Shapur sent gifts (munera) with Narses and that Constantius in turn sent gifts (munera) with Prosper, Spectatus, and Eustathius 17.5.15. This is the second time in Ammianus's history that he mentions diplomatic 
gifts. The first occasion is when Ammianus tells us that King Cottius of Gaul bestowed on Augustus carefully cleared paths through the Alps as a gift 15.10.2.

38 Ammianus Marcellinus 21.6 explains in a tone of mild disdain how Constantius gave gifts to the various Persian satraps and Armenian warlords in 360 to buy their loyalty when he was forced to go back west to deal with his cousin Julian's rebellion. Luxury clothing and many other sorts of gifts are specified, "cultu ambitioso indumentorum (the Armenian kings and Persian satraps) emercabantur et multiformibus donis." Within a few years, gift-giving appears to have become a standard part of Constantius's strategic arsenal. It is worth noting that Theodosius, father of the emperor Theodosius I, seems to have reverted back to the old ways when he handled the rebellion of the (Moorish and Donatist) general Firmus to whom he sends priests as envoys ("Christiani ritus antistites") and from whom he accepts gifts (missis muneribus), Ammianus Marcellinus 29.6.15-16. Ammianus appears conscious of Constantius's perceived weakness revealed in barbarous gift-giving when he emphasized that, upon Julian's accession to his throne in Constantinople, "barbarians" from the Rhine to the Ganges all sent him gifts, 22.7.10.

39 Aristotle, Politics, $1341 \mathrm{~b}$ ff., offers a good example describing how performing on a musical instrument demonstrates slavishness since the performer is acting to cause pleasure for others.

40 Eusebius, Life of Constantine 4.50, mentions the "Indians" sending a delegation to Con-

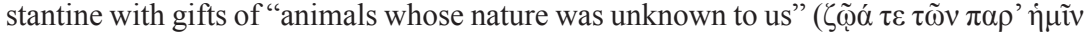

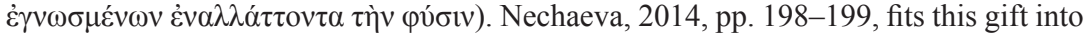
a long tradition and plausibly asserts that the "Indians" were the Himyarites. Eusebius cloaks his whole discussion of diplomacy in the Life of Constantine (Chapters 4.47 and 4.50 represent its entirety) in the traditional rhetoric that foreign gifts demonstrate Constantine's sole, glorious, and uncontested dominion from India to Britain.

41 Argued in Chapter 4.

42 Anthemius was praetorian prefect of the east at the child emperor's accession and is widely understood to have ruled for most of the first decade. For example, CTh 15.1.51 (413) has the emperor bestow credit for the new land wall in Constantinople on Anthemius. See, for instance, Blockley, 1992, pp. 52-59.

43 An attentive reader might suspect that Musonianus felt the need to "retire" in 358 shortly after this embassy due to the embarrassment he inflicted on Constantius via diplomatic miscues in 357-358. Adding Eustathius may have been one of these that Ammianus enjoyed calling to our attention.

44 Discussed in Chapter 4.

45 Becker, 2014a, demonstrates how the Romans from the 5th century on continued to frame their cultural superiority with gift exchange after they had lost military superiority. Deliyannis et al., 2019, claims ornate silver plates were used as Persian gifts as far back as the early-4th century. Bland, 2012, presents a convincing case for medallions as gifts to barbarians in the reign of Constantine, but these appear to be well below the level of serious international diplomacy and are also possibly rewards given to successful soldiers of barbarian lineage. Nechaeva, 2014, pp. 178-180, discusses later instances of horse (and mule) gifts.

46 Chapter 1.

47 Trimingham, 1978; Bowersock, 1980; Woods, 1996; Woods, 1998.

48 Chapter 5.

49 Swade, 1993; Toole, 1993.

50 An imitation of this machine now stands in the lobby of Intellectual Ventures in Bellevue, Washington.

51 Chapter 4.

1 Merrills and Miles, 2010, p. 123.

2 Liebeschuetz, 2003; Merrills and Miles, 2010. 
3 Liebeschuetz, 2003, supplies a concise and detailed history of the Vandal peoples.

4 Lapeyre, 1929, p. 11. Diesner, 1961, explores Fulgentius's youthful enthusiasm for eastern monasticism.

5 Chapter 3.

6 Dură, 2003.

7 PLRE Vitalianus 2, vol. 2, pp. 1171-1176, where some evidence is shared that he may have been of Gothic origin.

8 Comes and magister utriusque militiae praesentalis in the new regime of Justin, after five years of harassing and attacking the previous emperor, Anastasius, PLRE vol. 2, p. 1174.

9 Snaedal, 2009.

10 Chapter 5.

11 Liebeschuetz, 2003, p. 71, (citing Victor of Vita 2.55) mentions the Arian bishop Cyrila insisting that his discussion with a Nicene bishop be held in the Vandal language. This anecdote has similar implications to my reading of the epigram.

12 Shahid, 1964, pp. 116-119, Simeon of Beth Arsham representing the Miaphysite Christians of Persia; Isaac, a presbyter representing the Dyophysite ("orthodox") Christians of Persia; and Shilas, the ("Nestorian") catholicus of Persia.

13 The presence of an adequate number of Roman ships in the Red Sea raises questions similar to those discussed in Chapter 2.

14 Robin, 2010, pp. 70-75.

15 Greatrex, 1998, covers this war thoroughly and yet economically.

16 Robin, 2010, sums these up well.

17 If the subsequent Samaritan revolt of 529 is any evidence for religious hostility, anti-Jewish/Samaritan feelings in the empire were already running high. Procopius tells us that many Samaritans who had been feigning Christianity openly turned to "Manichaeanism," by which he may well have meant Persian Mazdakitism (Proc. SH 11.24).

18 The Palestinian Talmud was compiled in this traditional center of diaspora Judaism on the Sea of Galilee. The city never recovered its Jewish population after the persecutions, though it continued to be a center for Christian pilgrimage till it succumbed to Islamic rule in the 7 th century.

19 Book of Himyarites.

20 Nestorian Chronicles, Patrilogia Orientalis V, 331.

21 Pigulevskaya, 1960, and Pigulevskaya, 1961 is the most prominent.

22 Shahid, 1964.

23 Pseudo-Zacharias of Mitylene 8.5 tells us that Mundhir, on an expedition into Syria, sacrificed 400 nuns to a pagan goddess. In spite of this willingness to kill Christians (Miaphysite), his base in Persia was considered to consist of a large proportion of Nestorian Christians. So an open agreement to persecutions of Christians, in general, was not an option.

24 Smith, 1954, pp. 456-465 arguing from his interpretation of inscriptions.

25 Frye, 1983.

26 Vasiliev, 1950, p. 294, cites the histories of Hisham ibn Muhammed and ibn Iskhaq.

27 Martyrium Arethae 28.

28 Martyrium Arethae 29, Cosmas Indicopleustes 2.72 - also reported in Arabic sources, see Vasiliev, 1950, p. 295, n. 70.

29 Robin, 2010, p. 79.

30 Procopius, Wars 1.20.9.

31 Kruse, 2013.

32 Treadgold, 2007, p. 717.

33 Thurn, 2000, 18.56, translation modified from Smith, 1954, pp. 449-450.

34 Smith, 1954, pp. 449-450, Treadgold, 2007, p. 717.

35 Treadgold, 2007, p. 715. 
36 There is general agreement that Nonnosus's family, including his father Abraham, and his grandfather Euphrasius, all specialized diplomats to the Arabian world, originated somewhere in southern Mesopotamia and thus were recruited for cultural sensitivity and language skills, Bowersock, 2012, p. 285.

37 Braund, 1994, cites Priscus frs. 33 and 44 as well as Life of Daniel the Stylite 51. Braund sees in this episode an astute use of Christianity by Leo to strengthen Laz loyalty against the Sasanids.

38 For the Lazi and Iran in the 2nd half of the 5th century, see Menander 187 (de Boor); see also Braund, 1994, p. 276.

39 Agathias 3.5.4; Braund, 1991; Bertinelli, 1989, pp. 140-141.

40 Curta, 2019, explains the complexity of ethnicity in the 6th and 7th century Black Sea region as well as the need for archaeologists, historians, and linguists to cooperate in order to advance our now murky understanding.

41 J. Malalas, p. 361.

42 Malalas, pp. 361-362.

43 Engelhardt, 1974, p. 85, stresses the economic implications of Bosporus and its neighbor city Kherson: "Trotz der zahlreichen Hunneneinfälle bewahrten sie die griechische Kultur. Außerdem stellten sie die Hauptumschlagsplätze für den Handel zwischen Wolga- und Donbecken einerseits und Byzanz andererseits dar: Export von Getreide aus Kleinasien, Wein und Luxusgütern sowie Import von Fellen, Salz aus den Salinen von Cherson und Honigwaben wurden hier umgeschlagen." We will return to this key city below.

44 John of Nikiu (p. 141 in translation of R.H. Charles) makes Grepes a Hun, while John of Ephesus (Nau vol. 2, p. 475), John Malalas 356, George Cedrenus 1.643, and Michael the Syrian 2.192 call him a Herul. Cedrenus appears muddled calling him "Gretis of

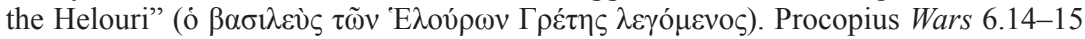
describes the Heruli at this time killing their own king, requesting a new one from Justinian named Suartuas, then abandoning him, and submitting to the Gepids. Due to this confusion, I am inclined to think that Malalas made an error ascribing Grepes to the Heruli and that this error entered the tradition. Within the context of Malalas's section on the Black Sea area, the discussion of the Balkan Heruli seems out of place. Considering all this, I am inclined to see Grepes as a king in the vicinity of Crimea as does Altheim (1961) vol. 3, p. 19.

45 Malalas 357.

46 Procopius, Wars 8.3.18-21.

47 Engelhardt, 1974, cites Reallexikon der Byzantinistik I.27 for a date of 543-546.

48 Seibt, 1992, p. 144, cites Zakaraia et al., 1979.

49 John of Ephesus HE 3.36-37.

50 Momigliano (1963) is the classic treatment of Eusebius's, and his genre's, factuality.

51 Proc. Wars 1.19.34.

52 Which Narses this was, acting under whose authority, and when are all significant questions for understanding Justinian's strategy. I tend to believe that Narses the eunuch had been sent to quell the uprising in Alexandria in 535 after which Theodosius, the patriarch, was expelled. Shortly thereafter, Narses the eunuch must have sent his client Narses, the so-called Persarmenian, to convert the temple of Isis at Philae. See Nautin, 1967.

53 Translation from Welsby (2002) 36.

54 For dating, see Grossmann, 1987, and Nautin, 1967. Liberatus Breviarium 20, an apparently independent source, assigns the mission to Theodora's authority alone.

55 Kush is the name most often used for the ancient civilization preceding the Nobadae, Merkurii, and Alodae in the Upper Nile valley. For the dating, see Welsby, 2002, p. 36.

56 Welsby, 2002, p. 37. 
57 See Török, 1988, p. 72: "It seems that the king of Nobatia who invited Theodore to continue Julian's missionary work is identical with King Eirpanome who ordered the erecting of a cross at Dendur sometime in the period of Theodore's Nubian activity (c. 545-551) or at the latest, before his death."

58 Welsby, 2002, p. 40, cites Edwards, 1994, and, for a similar situation at another site, Zurawski and el-Tayeb, 1994.

59 Welsby, 2002, p. 39, cites Zurawski, 1999.

60 Kirwan, 1987, reads the evidence to reach a conclusion opposed to mine. But the consensus of Shinnie, 1996, Török, 1988, and Welsby, 2002, against his conclusions has the virtue of being built on more recent excavations and interpretations.

61 Noonan, 2001, explicates the importance of Itil in the geopolitics of the 10th century.

62 Darrouzès, 1981, 3.619, catalogs the eight Gothic dioceses of the 10th century - a list that includes both Itil and Tmutorokan under the "archbishop of Gothia." Vernadsky, 1941, goes into convincing detail on the connection of this Gothic eparchy with Constantine's mission to the Khazars.

63 Featherstone, 2003, argues forcefully for the date 957 against several arguments for the date 946, Kresten, 2000, and Zuckerman, 2000.

64 Featherstone, 1990, pp. 297-305, includes an extensive English translation of the passages from the De Caeremoniis that highlight the remarkable extent and exquisite detail of diplomatic pageantry in the 10th century. In this case, Olga's visit is compared to that of Arab legates visiting from Amida and Corduba.

65 Cross and Sherbowitz-Wetzor, 1930, p. 121.

66 Raffensperger, 2007, p. 151.

67 Primary Chronicle, p. 117.

68 Ironically, Sophia's father, Thomas, fled the Ottoman attack on Constantinople to safety in Rome, where the pope paraded him in pomp as the newly declared Roman emperor in 1461. Sophia grew up in Rome, enjoying a remarkable Renaissance education under the tutelage of Cardinal Bessarion.

69 It should be noted that the Moscow mission was a failure, and by 1515, Kakheti was loyally bound to the Savafid shahs of Persia.

Altheim, F. and R. Stiehl, "Die Datierung des Königs Ezana von Aksum," Klio 39 (1961) 234-248.

Anfray, A., A. Caquot, and P. Nautin, "Une nouvelle inscription grecque d'Ezana, roi d'Axoum," Journal des savants (1970) 260-274.

Autiero, S., "Indian Ocean Trade: An Reassessment of the Pottery Finds," Vicino Oriente 19 (2015) 113-125.

Avi-Yonah, M., "The Development of the Roman Road System in Palestine," Israel Exploration Journal 1.1 (1950-51) 54-60.

Ballet, P., "De la Méditerranée à l'Océan Indien l’Égypte et le commerce de longue distance à l'époque romaine: les données céramiques," Topoi 5.2 (1996) 809-840.

Barnes, T.D., Athanasius and Constantius (Cambridge, 1993).

Bausi, A. (ed.), Languages and Cultures of Eastern Christianity: Ethiopia (London, 2012).

Black, S.L., "'In the Power of God Christ': Greek Inscriptional Evidence for the Anti-Arian Theology of Ethiopa's First Christian King," Bulletin of the School of Oriental and African Studies, University of London 71.1 (2008) 93-110.

Borstad, K., "History from Geography: The Initial Route of the Via Nova Traiana in Jordan," Levant 40.1 (2008) 55-70.

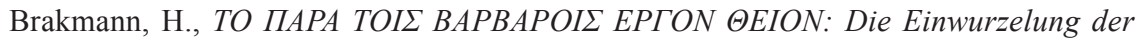
Kirche im spätantiken Reich von Aksum (Bonn, 1994). 
Brennecke, H., “Zwei Apologien des Athanasius an Kaiser Constantius II," Zeitschrift für Antikes Christentum 10.1 (2007) 67-85.

Briquel-Chatonnet, F., "L'expansion du christianisme en Arabie: l'apport des sources syriaques," Semetica et Classica 10 (2010) 177-188.

Burstein, S., "Ivory and Ptolemaic Exploration of the Red Sea: The Missing Factor," Topoi 6.2 (1996) 799-807.

Buschmann, K., "Motiv und Ziel des Aelius-Gallus-Zuges nach Südarabien," Die Welt des Orients 22 (1991) 85-93.

Casson, L., The Periplus of the Erythraean Sea (London, 1976).

Cerulli, E., "Perspectives on the History of Ethiopia," in A. Bausi (ed.), Languages and Cultures of Eastern Christianity (London, 2012) pp. 1-25.

Cracco Ruggini, L., "Leggenda e realtà degli Etiopi nella cultura tardo-imperiale," in Atti de IV congresso internazional di studi Etiopici (Rome, 1974) pp. 1:141-193.

Cuvigny, H. (ed.), La route de Myos Hormos: L'armée romaine dans le desert Orientale d'Égypte (Paris, 2003).

Deramay, J., "Introduction et restauration du christianism en Abyssinie (330-480)," Revue de l'histoire des religions 31 (1895) 131-161.

De Romanis, F. and A. Tchernia (eds.), Crossings - Early Mediterranean Contacts with India (New Delhi, 1997).

Desanges, J., "D'Axoum à l'Assam, aux portes de la Chine: Le Voyage du 'Scholasticus de Thèbes' (entre 360 et 500 après J.-C.)," Historia 18.5 (1969) 627-639.

Dihle, A., "L'Ambassade de Théophile l'Indien ré-examinée," in T. Fahd (ed.), L'Arabie préislamique et son environnement historique et culturel: Actes du Colloque de Strasbourg, juin 1987 (Leiden, 1989) vol. 2, pp. 461-468.

Dijkstra, M. and A.M.F.W. Verhoogt, "The Greek-Palmyrene Inscription," in S. Sidebotham (ed.), Berenike 1997: Report of the 1997 Excavations at Berenike (1999) pp. 208-218.

Dombrowski, B.W.W., "Frumentius/Abbâ Salâmâ: Zu den Nachrichten über die Anfänge des Christentums in Äthiopien," Oriens Christianus 68 (1984) 114-169.

Dridi, H. and M. Gorea, "La Grotte Sanctuaire de Suqutra," Archéologia 396 (2003) $48-57$.

Engels, D.W., Alexander the Great and the Logistics of the Macedonian Army (Berkeley, 1978).

Facey, W., "The Red Sea: The Wind Regime and Location of Ports," in P. Lunde and A. Porter (eds.), Trade and travel in the Red Sea region: Proceedings of the Red Sea Project 1. Held in the British Museum October 2002 (Oxford, 2002) pp. 7-17.

Gadja, I., "Quel monothéisme en Arabie du sud ancienne?" in J. Beaucamp, F. BriquelChatonnet and C.J. Robin (eds.), Juifs et Chrétiens en Arabie aux Ve et VIe Siècles (Paris, 2010) pp. 107-120.

Haas, C., "The Alexandrian Riots of 356 and George of Cappadocia," Greek Roman and Byzantine Studies 32.3 (1991) 281-301.

Haas, C., Alexandria in Late Antiquity: Topography and Social Conflict (Baltimore, 2006).

Haas, C., "Mountain Constantines: The Christianization of Aksum and Iberia," Journal of Late Antiquity 1.1 (2008) 101-126.

Haile, G., "The Homily in Honour of St. Frumentius Bishop of Aksum (EMML 1763 ff. 84v-86r)," Analecta Bollandiana 97 (1979) 309-318;

Hellyer, P., "Nestorian Christianity in the Pre Islamic UAE and Southeastern Arabia," Journal of Social Affairs 18.72 (2001) 79-99. 
Kennett, D., "The Decline of Eastern Arabia in the Sasanian Period," Arabian Archaeology and Epigraphy 18 (2007) 86-122.

Loreto, R., "Recent Studies in Pre-Islamic Yemen: An Overview," Rassegna di Studi Etiopici 4 (2012) 239-266.

Lunde, P. and A. Porter (eds.), Trade and Travel in the Red Sea Region: Proceedings of Red Sea Project I Held in the British Museum (Oxford, 2004).

Mairs, R., "Greek Identity and the Settler Community in Hellenistic Bactria and Arachosia," Migrations and Identities 1.1 (2008) 19-43.

Martin, A., Histoire 'Acéphale'et Index Syriaque des lettres festales d'Athanased'Alexandrie (Paris, 1985).

Martin, A., Athanase d'Alexandrie et l'église d'Égypte au Ive Siècle (328-373) (Paris, 1996).

Martin, L.R., "Horse and Cargo Handling on Medieval Mediterranean Ships," International Journal of Nautical Archaeology 31.2 (2002) 237-247.

Mayerson, P., "The Port of Clysma (Suez) in Transition from Roman to Arab Rule," Journal of Near Eastern Studies 55.2 (1996a) 119-126.

Mayerson, P., "Egeria and Peter the Deacon on the Site of Clysma (Suez)," Journal of the American Research Center in Egypt 33 (1996b) 61-64.

Munro-Hays, S.C.H., "The Dating of Ezana and Frumentius," Rassegna di Studi Etiopici 32 (1988) 111-127.

Munro-Hays, S.C.H., “Aksumite Overseas Interests,” Northeast African Studies 13.2/3 (1991) 127-140.

Nedungatt, G., "India Confused with Other Countries in Antiquity?" Orientalia Christiana Periodica 76.2 (2010) 315-333.

Peppard, M., "A Letter Concerning Boats in Berenike and Trade on the Red Sea," Zeitschrift für Papyrologie und Epigraphik 171 (2009) 193-198.

Phillips, J., "Punt and Aksum: Egypt and the Horn of Africa," The Journal of African History 38.3 (1997) 423-457.

Prioletta, A., "I musei dello Yemen: Nuovi documenti di Dhamār: la regione dal periodo dei mukarrib di Saba' fino all formazione de Himyar," Egitto e Vicino Oriente 31 (2008) 193-211.

Raith, M., P. Yule, and K. Damgaard, "The View from Zafar: An Archaeometric Study of the Aqaba Pottery Complex and Its Distribution in the 1st Millennium CE," Zeitschrift für Orient-Archäologie 6 (2013) 318-348.

Ramelli, I.L.E., "Early Christian Missions from Alexandria to 'India'. Institutional Transformations and Geographical Identifications," Augustinianum 51 (2011) 221-231.

Rasul, N. and I. Stewart (eds.), The Red Sea: The Formation, Morphology, Oceanography and Environment of a Young Ocean Basin (Heidelberg, 2015).

Redmount, C.A., "The Wadi Tumilat and the 'Canal of the Pharaohs'," Journal of Near Eastern Studies 54.2 (1995) 127-135.

Robin, C.J., "L'institution monarchique en Arabie du Sud antique: les contributions fondatrices d'A.F.L. Beeston réexaminées à lumière des découvertes les plus récentes," Proceedings of the Seminar for Arabian Studies 36 (2006) 43-52.

Schneider, R., “A New Aksumite Chronology,” Journal of Ethiopian Studies 21 (1988) 111-120.

Seland, E.H., "Archaeology of Trade in the West Indian Ocean 300 BC-AD 700," Journal of Archaeological Research 22 (2014) 367-402.

Selassie, S.H., Ancient and Medieval Ethiopian History till 1270 (Addis Ababa, 1972).

Sidebotham, S.E., Berenike and the Ancient Maritime Spice Route (Berkeley, 2011). 
Sidebotham, S.E., "Religion and the Burial at the Ptolemaic-Roman Red Sea Emporium of Berenike, Egypt," African Archaeological Review 31 (2014) 599-635.

Sidebotham, S.E. and J.E. Gates-Foster, The Archaeological Survey of the Desert Roads Between Berenike and the Nile Valley (Boston, 2018).

Sidebotham, S.E. and R.E. Zitterkopf, "Routes through the Eastern Desert," Expedition 37.2 (1995) 39-52.

Stark, R., The Triumph of Christianity: How the Jesus Movement Became the World's Largest Religion (2012).

Sterk, A., "Mission from Below: Captive Women and conversion on the East Roman Frontiers," Church History 79.1 (2010) 1-39.

Stroumsa, G.G., "Jewish Christianity and Islamic Origins," in B. Sadeghi, A.Q. Ahmed, A. Silverstwein, and R. Hoyland (eds.), Islamic Cultures, Islamic Contexts (Leiden, 2015) pp. 72-96.

Tobi, Y., "The Jews of Yemen in Light of the Excavation of the Jewish Synagogue in Qanī'," Proceedings of the Seminar for Arabian Studies 43 (2013) 349-356.

Tomber, R., "From the Roman Red Sea to beyond the Empire: Egyptian Ports and their Trading Partners," British Museum Studies in Ancient Egypt and Sudan 18 (2012) 201-215.

Ward, W., "Aila and Clysma: The Rise of Northern Ports in the Red Sea in Late Antiquity," in J. Starkey, P. Starkey, and T. Wilkinson (eds.), Natural Resources and Cultural Connections of the Red Sea (Oxford, 2007) pp. 161-171.

Warmington, B.H., "Ammianus Marcellinus and the Lies of Metrodorus," Classical Quarterly 31.2 (1981) 464-468.

Wendrich, W.S, R.S. Tomber, S.E. Sidebotham, J.A. Harrell, R.T.J. Cappers, and R.S. Bagnall, "Berenike Crossroads: The Integration of Information," Journal of the Economic and Social History of the Orient 46.1 (2003) 46-87.

Woods, D., "Three Notes on Aspects of the Arian Controversy c. 354-367 CE," The Journal of Theological Studies N.S. 44.2 (1993) 604-619.

Youinou, F., "Trois nations pour une ambassade: l'<énigme Métrodore $>$ Christianisation et relations internationales au IVe siècle ap. J.-C.: l'exemple de la question d'Orient sous Constantin," Latomus 67.1 (2008) 149-165.

Zitterkopf, R.E., "Routes through the Eastern Desert," Expedition 37.2 (1995) 39-52.

Aland, K. et al., The Greek New Testament (Stuttgart, 1968).

Barnes, T.D., Constantine and Eusebius (Boston, 1981).

Barnes, T.D., "The Capitulation of Liberius and Hilary of Poitiers," Phoenix 46.3 (1992a) 256-265.

Barnes, T.D., "Hilary of Poitiers on His Exile," Vigiliae Christianae 46 (1992b) 129-140.

Barnes, T.D., Athanasius and Constantius (Cambridge, 1993).

Barnes, T.D., "The Crimes of Basil of Ancyra," Journal of Theological Studies 47.2 (1996) $550-555$.

Barnes, T.D., "The Exile and Recalls of Arius," Journal of Theological Studies 60 (2009) 109-129.

Beckwith, C., "The Condemnation and Exile of Hilary of Poitiers at the Synod of Béziers (356 CE)," Journal of Early Christian Studies 13.1 (2005): 21-38.

Beckwith, C., Hilary of Poitiers on the Trinity (Oxford, 2008).

Bidez, J., Philostorgius Kirchengeschichte (Berlin, 1913).

Bidez, J. and G.C. Hansen (eds.), Sozomenus. Kirchengeschichte (Berlin, 1960).

Bladeau, P. (ed.), Exil et relégation: les tribulations du sage et du saint durant l'Antiquité romaine et chrétienne (Ier-VIe s. ap. J.-C.) (Paris, 2008). 
Brennecke, H.C., Hilarius von Poitiers und die Bischopfsopposition gegen Konstantius II (Berlin, 1984).

Brennecke, H.C, "Zwei Apologien von Athanasius an Kaiser Konstantius II," Zeitschrift für Antikes Christentum 10.1 (2006) 67-85.

Brennecke, H.C., U. Heil, and A. von Stockhausen (eds.), Athanasius Werke: Zweiter Band “die Apologien," (Berlin, 2006).

Caspari, C.P., Kirchenhistorische anecdota: nebst neuen Ausgaben partistischer und kirchlich-mittelalterlicher Schriften, vol. 1 (Oslo, 1883).

Crouzel, H., "Un résistant toulousain à la politique pro-arienne de l'empereur Constance II: l'evêque Rhodanius," Bulletin de littérature ecclésiastique 77 (1976): 173-190.

Dattrino, L., "Eusebio di Vercelli, vescovo, monaco, martire," Salesianum 72 (2010) 699-720.

de Senneville-Grave, G. (ed.), Sulpice Sévère Chroniques (Paris, 1999).

Drake, H., Constantine and the Bishops (Baltimore, 2000).

Drijvers, H.J., Cyril of Jerusalem: Bishop and City (Leiden, 2004).

Duffy, J. and J. Parker (eds.), The Synodicon Vetus (Washington, DC, 1979).

Fiedrowicz, M., "Paulinus von Trier - ein frühchristlicher Bekennerbischof im Spannungfeld von Kirche und Staat," Trierer theologische Zeitschrift 119.2 (2010) 149-164.

Fisher, C.D. (ed.), Tacitus Annals (Oxford, 1977).

Foerster, R. (ed.), Libanii Opera (Leipzig, 1908).

Fournier, E., "Exiled Bishops in the Christian Empire: Victims of Imperial Violence?," in H.A. Drake (ed.), Violence in Late Antiquity (Burlington, VT, 2006) pp. 157-166.

Gentili, S., "Politics and Christianity in Aquileia in the Fourth Century A.D.," L'Antiquité Classique 61 (1992).

Girardet, K.M., "Constance II, Athanase et l'édit d'Arles (353)," in C. Kannengiesser (ed.), Politique et Théologie chez Athanase d'Alexandrie (Paris, 1974a) pp. 63-91.

Girardet, K.M., “Appellatio: Ein Kapitel kirchlicher Rechtsgeschichte in den Kanones des vierten Jahrhunderts," Historia 23.1 (1974b) 98-127.

Girardet, K.M., Kaisergericht und Bischofsgericht: Studien zu den Anfängen des Donatistenstreites, 313-15, und zum Prozess des Athanasius von Alexandrien, 328-46 (Bonn, 1975).

Girardet, K.M., "Die Petition der Donatisten an Kaiser Konstantin (Frühjahr 313) historische Voraussetzungen und Folgen," Chiron 19 (1989) 186-206.

Girardet, K.M., "Gericht über den Bischof von Rom. Ein Problem der kirchlichen un der staatlichen Justiz in der Spätantike (4.-6. Jahrhundert)," Historische Zeitschrift 259.1 (1994) 1-38.

Girardet, K.M., Die konstantinische Wende: Voraussetzungen und geistige Grundlagen der Religionspolitik Konstantins des Grossen (Darmstadt, 2007).

Girardet, K.M., Kaisertum, Religionspolitik und das Recht von Staat und Kirche in der Spätantike (Bonn, 2009).

Girardet, K.M., Der Kaiser und sein Gott: das Christentum im Denken und in der Religionspolitik Konstantins des Grossen (Berlin, 2010).

Gorman, R., "Poets, Playwrights, and the Politics of Exile and Asylum in Ancient Greece and Rome," International Journal of Refugee Law 6.3 (1994) 402-424.

Gwynn, D., The Eusebians (Oxford, 2006).

Haas, C., Alexandria in Late Antiquity (Baltimore, 1997).

Hein, K., Eucharist and Excommunication: A Study in Early Christian Doctrine and Discipline (Frankfurt, 1975).

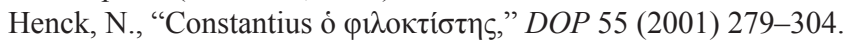


Holl, K., Epiphanius, Band 2: Panarion (Leipzig, 1922).

Kalleres, D., "Cultivating True Sight at the Center of the World: Cyril of Jerusalem and the Lenten Catechumenate," Church History 74.3 (2005) 431-459.

Kelly, C., Ruling the Later Roman Empire (London, 2004).

Lieu, S. and D. Montserrat, From Constantine to Julian: Pagan and Byzantine Views: A Source History (London, 1996).

Maraval, P. and P. Périchon (eds.), Socrate de Constantinople, Histoire ecclésiastique (Paris, 2004-7).

Mayer, W., "The Bishop as Crisis Manager: An Exploration of Early Fifth-Century Episcopal Strategy," in D. Luckensmeyer and P. Allen (eds.), Studies of Religion and Politics in the Early Christian Centuries (Strathfield, 2010) pp. 159-171.

Mirri, L.M., "Riferimenti patristici nei concili del sec. IV in Gallia," Annuarium historiae conciliorum; internationale Zeitschrift für Konziliengeschichtsforschung 35 (2003) 186-199.

Opitz, H.G. (ed.), Athanasius Werke (Berlin, 1934).

Parmentier, L. and F. Scheidweiler (eds.), Theodoret Kirchengeschichte (Berlin, 1954).

Parvis, S., Marcellus of Ancyra and the Lost Years of the Arian Controversy, 325-45 (Oxford, 2006).

Pfeiffer, M., Paenitentia Secunda: Das kirkliche Bußverfahren in Frühen Christentum (Leipzig, 2003).

Rapp, C., Holy Bishops in Late Antiquity (Berkeley, 2006).

Rocher, A., Contre Constance (Paris, 1987).

Rolfe, J.C. (ed.), Suetonius (Cambridge, MA and London, 1914).

Schwartz, E., Gesammelte Schriften (Berlin, 1959).

Seyfarth, W., Ammiani Marcellini Rerum Gestarum Libri Qui Supersunt (Leipzig, 1978).

Silli, P., Testi costantiniani nelle fonti literarie (Milan, 1987).

Simpson, A., Niketas Choniates: A Historigraphical Study (Oxford, 2013).

Speller, E., "A Note on Eusebius of Vercelli and the Council of Milan," Journal of Theological Studies 36 (1985) 157-165.

Stini, F., Plenum exiliis mare: Untersuchungen zum Exil in der römischen Kaiserzeit (Stuttgart, 2011).

Tietze, W., Lucifer von Calaris und die Kirchenpolitik des Constantius II (Tübingen, 1976).

Van Dam, R., The Roman Revolution of Constantine (Cambridge, 2007).

Washburn, D., "Tormenting the Tormentors: A Reinterpretation of Eusebius of Vercelli's Letter from Scythopolis," Church History 78.4 (2009) 731-755.

Washburn, D., Banishment in the Later Roman Empire, 284-476 CE (New York, 2013).

Winkelmann, F. (ed.), Eusebius Werke Band 1: über das Leben des Kaisers Konstantin (Berlin, 1975).

Winkelmann, F. (ed.), Philostorgius Kirchengeschichte (Berlin, 1981).

Wirbelau, E., "Exil für den römischen Bischof?," Saeculum 59 (2008) 29-46.

Woods, D., "The Date of the Translation of the Relics of SS. Luke and Andrew to Constantinople," Vigiliae Christianae 45.3 (1991) 286-292.

Arias Bonet, J.A., "Los agentes in rebus. Contribucion a estudio de la policia en al Bajo Imperio Romano," Anuario de historia del derecho español 27-28 (1957) 197-219.

Austin, N. and B. Rankov, Exploratio: Military and Political Intelligence in the Roman World From the Second Punic War to the Battle of Adrianople (London, 1995).

Becker, A., "Les modalités pratiques de la diplomatie romano-barbare dans le Code Théodosien," Quaderni camerti di studi romanistici 43 (2015) 103-117. 
Blum, W., Curiosi und Regendarii. Untersuchungen zur Geheimen Staatspolizei der Spätantike (Munich, 1969).

Bogaert, R., “Les opérations des banques de l'Égypt romaine,” Ancient Society 30 (2000) 135-269.

Boulenger, J.C., De Imperatore et Imperio Romano Libri XII (Lyon, 1618).

Bowersock, G., "Mavia, Queen of the Saracens,"in W. Eck, H. Galsterer, and H. Wolff (eds.), Studien zur antiken Sozialgeschichte: Festschrift Friedrich Vittinghoff (Vienna, 1980) pp. 477-495.

Bradbury, S., Selected Letters of Libanius from the Age of Constantius and Julian (Liverpool, 2004).

Cottier, M., "The Customs Districts of Roman Egypt," Proceedings of the Twenty-Fifth International Congress of Papyrology (2010) 141-148.

Drijvers, J.W., “Ammianus Marcellinus 15.13.1-2: Some Observations on the Career and Bilingualism of Strategius Musonianus," Classical Quarterly 46.2 (1996) 532-537.

Dvornik, F., Origins of Intelligence Services: The Ancient Near East, Persia, Greece, Rome, Byzantium, the Arab Muslim Empires, the Mongol Empire, China, Muscovy (New Brunswick, NJ, 1974).

Foerster, R. (ed.), Libanius, Opera (Leipzig, 1903-1927).

Ghica, V., "Pour une histoire du christianisme dans le désert occidental d'Égypte," Journal des savants 2 (2012) 189-280.

Giardina, A., Aspetti della burocrazia nel basso impero (Rome, 1977).

Gignout, P., Les quatre inscriptions du Mage Kirdir (Paris, 1991).

Haas, C., Alexandria in Late Antiquity (Baltimore, 1996).

Hamilton, W. (trans.), Ammianus Marcellinus: The Later Roman Empire (A.D. 354-378) (London, 1986).

Hansen, G.C., Anonyme Kirchengeschichte (Berlin and New York, 2002).

Hartmann, U., "Die Parthischen Stationen des Isidor von Charax: eine Handelsroute, eine Militärkarte oder ein Werk geographischer Gelehrsamkeit?" in J. Wiesehöfer and S. Müller (eds.), Parthika: Greek and Roman Authors' Views of the Arsacid Empire (Wiesbaden, 2017) pp. 87-125.

Hercher, R. (ed.), Epistolographi Graeci (Paris, 1873).

Hirschfeld, O., "Die agentes in rebus," Sitzungsberichte der Königlish Preussischen Akademie der Wissenschaften zu Berlin (1893) 421-441.

Holl, K., Epiphanius, Bände 1-3 (Leipzig, 1915, 1922, 1933).

Jerphagnon, L., "Une curiosité: les agentes in rebus dans l'oeuvre de saint Augustin," in P. Defosse (ed.), Hommages à Carl Deroux. V. Christianisme et Moyen Âge. Néolatin et survivance de la latinité (Brussels, 2003) pp. 165-169.

Jones, A.H.M., A.H.M. Martin, J.R. Martindale, and J. Morris, The Prosopography of the Later Roman Empire, vol. 1 (Cambridge, 1971).

Kelly, G., Ammianus Marcellinus: The Allusive Historian (Cambridge, 2008).

Lee, A.D., Information and Frontiers (Cambridge, 1993).

Lenski, N., "Valens and the Monks: Cudgeling and Conscription as a Means of Social Control," Dumbarton Oaks Papers 58 (2004) 93-117.

Luisier, P., "Les années de l'indiction dans les inscriptions des Kellia," Zeitschrift für Papyrologie und Epigraphik 159 (2007) 217-222.

Marcos, M., "Some Notes on the Backchannel Communications of the Prefect Musonianus with the Persians," Historia 61.4 (2012) 507-510.

Millar, F., "Linguistic Co-existence in Constantinople: Greek and Latin (and Syriac) in the Acts of the Synod of 536 C.E.," Journal of Roman Studies 99 (2009) 92-103. 
Mommsen, T., Theodosiani Libri XVI (Berlin, 1905).

Moser, M., Emperor and Senators in the Reign of Constantius II (Cambridge, 2018).

Paschoud, F., Frumentarii, Agentes in rebus, Magistriani, Curiosi, Veredarii: problèmes de terminologie (Bonn, 1983).

Purpura, G., "I Curiosi e la schola agentum in rebus," Annali del Seminario Giuridico della Università di Palermo 34 (1973) 166-273.

Russell, N. (trans.), Cyril of Alexandria (London, 2000).

Scholten, H., "Römische Diplomatie im 4. Jhd. n.Chr.: eine Doppelstrategie des praefectus praetorio Orientis Musonianus?" Historia 47.4 (1998) 454- 467.

Seager, R., "Rome and Persia 357-9: The Role of Tamsapor," in C.S. Kraus, J. Marincola, and C. Pelling (eds.), Ancient Historiography and its Contexts: Studies in Honour of A. J. Woodman (Oxford, 2010) pp. 155-164.

Sheldon, R.M, Espionage in the Ancient World (London, 2003).

Sinnegan, W., "Two Branches of the Late Roman Secret Service," American Journal of Philology 80.3 (1959) 238-254.

Thomas, J.D., "Epigraphai and Indictions in the Reign of Diocletian," The Bulletin of the American Society of Papyrologists 15.1/2 (1978) 133-145.

Trimingham, J.S., "Mawiyya: The First christian Arab Queen," The Near East School of Theology Theological Review 1.1 (1978) 3-10.

Woods, D., "Strategius and 'Manichaeanism'," Classical Quarterly 51.1 (2001) 255-264.

Albert, G., Goten in Konstantinopel: Untersuchungen zur oströmischen Geschichte um das Jahr 400 n. Chr. (Munich, 1984).

Allen, P. and W. Mayer, John Chrysostom (London, 2000).

Barnes, T.D. and G. Bevan (trans.), Funeral Speech for John Chrysostom (Liverpool, 2013).

Barry, J., “Diagnosing Heresy: Ps.-Martyrius' Funeral Speech for John Chrysostom,” Journal of Early Christian Studies 24.3 (2016) 395-418.

Battifol, P., "De quelques homélies de S. Jean Chrysostome et de la version gothique des écritures gothiques," Revue Biblique 8 (1899) 566-572.

Cosentino, S., "Social Instability and Economic Decline of the Ostrogothic Community in the Aftermath of the Imperial Victory: The Papyri Evidence," in J. Herrin and J. Nelson (eds.), Ravenna: Its Role in Earlier Change and Exchange (London, 2016) pp. 133-149.

Delgado Jara, I., "Los ultimos años del episcopado de san Juan Cristóstomo," Helmantica 54 (2003) 269-294.

Dolezal, S., "Joannes Chrysostomos and the Goths," Graecolatina Pragensia 21 (2006) $165-185$.

Gambacorta, F., "The Silver Coinage of Aelia Eudoxia (400-404) in the Light of Two New Light Miliarenses," The Numismatic Chronicle 171 (2011) 197-202.

Girardi, M., "Dinamiche multietniche ed interreligiose sul Limes Danubiano nel IV secolo: il martirio di Saba il Goto," Classica et Christiana 7.1 (2012) 117-141.

Goodspeed, E.J., Die ältesten Apologeten (Göttingen, 1915).

Green, D.H., "Linguistic and Literary Traces of the Ostrogoths," in S.J. Barnish and F. Marazzi (eds.), The Ostrogoths from the Migration Period to the Sixth Century: An Ethnographic Perspective (Oxford, 2008) pp. 387-404.

Gryson, R., Scolies Ariennes sur le concile d'Aquilé (Paris, 1980).

Gwynn, D., The Eusebians: The Polemic of Athanasius of Alexandria and the Construction of the 'Arian Controversy,' (Oxford, 2007). 
Gwynn, D., "Archaeology and the 'Arian Controversy' in the Fourth Century," in D. Gwynn and S. Bangert (eds.), Religious Diversity in Late Antiquity (Leiden, 2010) pp. 229-263.

Heather, P., The Goths and Romans 332-489 (Oxford, 1991).

Ivanov, S., Vizantiinskoe Missionerstvo (Moscow, 2003).

Kalleres, D., "Cultivating True Sight at the Center of the World: Cyril of Jerusalem and the Lenten Catechumenate," Church History 74.3 (2005) 431-459.

Kelly, J.N.D., Golden Mouth (Ithaca, NY, 1995).

Laird, R., "John Chrysostom and the Anomoeans: Shaping an Antiochene Perspective on Christology," in W. Mayer and B. Neil (eds.), Religious Conflict from Early Christianity to the Rise of Islam (Berlin, 2013) pp. 129-150.

Lenski, N., "The Date of the Gothic Civil War and the Date of the Gothic Conversion," Greek, Roman, and Byzantine Studies 36.1 (1995) 51-87.

Malingrey, A.M., J. Daniélou, and R. Flacelière (eds.), Jean Chrysostome. Sur l'incompréhensibilité de Dieu (Paris, 1970).

Malingrey, A.M., Jean Chrysostome: Lettres à Olympias (Paris, 1968).

Mayer, M., "Constantinopolitan Women in John's Circle," Vigiliae Christianae 53.3 (1999) 265-288.

Mayer, W., "John Chrysostom as Bishop: The View from Antioch," Journal of Ecclesiastical History 55.3 (2004) 455-466.

Mayer, W., "The Audience(s) for Patristic Social Teaching: A Case Study," in B.J. Matz and J. Verstraeten (eds.), Reading Patristic Texts on Social Issues: Issues and Challenges for the Twenty-First Century (Washington, DC, 2011) pp. 85-99.

Mayer, W., "Re-theorizing Religious Conflict: Early Christianity to Late Antiquity and Beyod," in W. Mayer and C.L. de Wet (eds.), Reconceiving Religious Conflict: New Views from the Formative Centuries of Christianity (London, 2018a) pp. 3-29.

Mayer, W., "Media Manipulation as a Tool in Religious Conflict: Controlling the Narrative Surrounding the Deposition of John Chrysostom," in W. Mayer and C.L. de Wet (eds.), Reconceiving Religious Conflict: New Views from the Formative Centuries of Christianity (London, 2018b) pp. 151-168.

Nigro, G.A., "Niceta, Inna, e altri martiri goti," Annali di storia dell'esegesi 29.1 (2012) 131-147.

Poguntke, A., "Das römische Heermeisteramt im 5. Jahrhundert: Überlegungen zum Verhältnis zwischen Kaiser und Heermeister in Ost und West," in C. Föller and F. Schulz (eds.), Osten und Westen 400-600 n. Chr.: Kommunication, Kooperation, und Konflikt (Stuttgart, 2016) pp. 239-262.

Reischl, W.C. and J. Rupp (eds.), Cyrilli Hierosolymorum archiepiscopi opera quae supersunt omnia (Munich, 1848).

Schäferdiek, K., "Johannes Chrysostomos und die Wulfilanische Kirchensprache," Zeitschrift für Kirchengeschichte 117 (2006) 289-296.

Sibiescu, V.G., "L'activité missionaire de saint Jean Chrysostom parmi les Goths: VIIIe homélie," Glasul Bisericii 32 (1973) 375-388 (in Romanian).

Sivan, H., "Wulfila's Own Conversion," Harvard Theological Review 89.4 (1996) $375-377$.

Stanfill, J., "John Chrysostom's Gothic Parish and the Politics of Space," Studia Patristica 15 (2013) 345-349.

Stanfill, J., Embracing the Barbarian: John Chrysostom's Pastoral Care of the Goths (Fordham University, 2015).

Thomson, E.A., The Visigoths in the Time of Ulfila (Oxford, 1966). 
Van Nuffelen, P., "Theophilus against John Chrysostom: The Fragments of a Lost liber and the Reasons for John's Deposition," Adamantius 19 (2013) 139-155.

Voicu, S.J., "In Pentecosten sermo 1 (PG 52.803-808; CPG 4536): il problema dell'autenticità," in M. Maritano (ed.), Historiam perscrutari: miscellanea di studi offerti al prof. Ottorino Pasquato (Rome, 2002) pp. 849-861.

Ward-Perkins, B., "Where is the Archaeology and Iconography of Germanic Arianism?" Journal of Late Antique Archaeology 6.1 (2010) 265-289.

Washburn, D., "The Letter Collection of John Chrysostom," in C. Sogno, B.K. Sorin, and E.J. Watts (eds.), Late Antique Letter Collections: A Critical Introduction and Reference Guide (2016) pp. 190-204.

Wenger, A., "Notes inédites sur les empereurs Théodose I, Arcadius, Théodose II, Léon I," Revue des études byzantines 10 (1952) 47-59.

Winkelmann, F., Historia ecclesiastica (fragmenta apud Photium): Philostorgius. Kirchengeschichte (Berlin, 1981).

Wolfram, H., History of the Goths (Berkeley, CA, 1988).

Zuckerman, C., "Cappadocian Fathers and the Goths," Travaux et Mémoires du Centre de rescherche d'histoire et civilization de Byzance 11 (1991) 473-486.

Abka'i-Khavari, M., Das Bild des Königs in der Sasanidenzeit (Hildesheim, 2000).

Alram, M., "Early Sasanian Coinage," in V. Curtis and S. Stewart (eds.), The Sasanian Era (London, 2008) pp. 17-30.

Ashkelony, B.B. and A. Kofsky, Christian Gaza in Late Antiquity (Leiden, 2004).

Berti, V., "Il cristianesimo siriaco. Protaginisti, stagioni e node problematice dalla prima evangelizzazione all'esordio del V secolo," in S. Ronchey (ed.), Costantino I: enciclopedia costantiniana sulla figura e l'immagine dell'imperatore del cosidetto editto di Milano 313-213 (Rome, 2013) pp. 849-861.

Brière, M., "Un homélie inédite d'Atticus," Revue de l'Orient Chrétien 9 (1933) 160-186.

Briquel-Chatonnet, F., "L'expansion du christianisme en Arabie: l'apport des sources syriaques," Semitica et Classica 3 (2010) 177-188.

Briquel-Chatonnet, F. and A. Desreumaux, "Oldest Syriac Christian Inscription Discovered in North-Syria," Hugoye: Journal of Syriac Studies 14.1 (2011) 45-61.

Brock, S., "Some Aspects of Greek Words in Syriac," in A. Dietrich (ed.), Synkretismus im syrisch-persischen Kulturgebiet (Göttingen, 1975) pp. 80-108.

Brock, S., "Christians in the Sasanian Empire: A Case of Divided Loyalties," Studies in Church History 17 (1982a) 1-19.

Brock, S., "The Homily by Marutha of Tagrit on the Blessing of the Waters at Epiphany," Oriens Christianus 66 (1982b) 51-74.

Brock, S., "Eusebius and Syriac Christianity," in H.W. Attridge and G. Hata (eds.), Eusebius, Christianity, and Judaism (Detroit, MI, 1992) pp. 212-234.

Brock, S., 'L'église de l'Orient dans l'empire sassanide jusqu'au VI' siècle et son absence aux conciles de l'Empire romain," Istina 40 (1995), pp. 25-43.

Brown, P., "The Diffusion of Manichaeism in the Roman Empire," Journal of Roman Studies 59 (1969) 92-103.

Canepa, M., The Two Eyes of the Earth: Art and Ritual of Kingship between Rome and Sasanian Iran (Berkeley, 2009).

Canivet, P. and A. Leroy-Molinghen (eds./trans.), Théodoret de Cyr, Histoire des moines de Syrie (Paris, 1977).

Chabot, J.B., Synodicon Orientale (Paris, 1902). 
Chaumont, M.-L., "Les Sassanides et la christianisation de l'Empire iranien au IIIe siècle de notre ère," Revue de l'histoire des religions 165.2 (1964) 165-202.

Chaumont, M.-L., La christianisation de l'empire Iranien (Louvain, 1988).

Corbier, M., "Rome, un empire bilingue," in L. Villard (ed.), Langues dominantes, Langues dominées (Rouen, 2008) pp. 30-55.

Daryaee, T., Sasanian Iran (224-651CE): Portrait of a Late Antique Empire (Costa Mesa, CA, 2008).

Decret, F., "Les conséquences sur le christianisme en Perse de l'affrontement des empires romain et sassanide: de Shâpûr I ${ }^{\text {er }}$ à Yazdgard I Ir, " Études augustiniennes 14 (1979) 91-152.

Edwell, P., "Sasanian Interactions with Rome and Byzantium," in D. Potts (ed.), Oxford Handbook of Ancient Iran (Oxford, 2013) pp. 840-855.

Erhart, V., "The Development of Syriac Christian Canon Law in the Sasanian Empire," in R. Mathisen (ed.), Law, Society and Authority in Late Antiquity (Oxford, 2001) pp. 115-129.

Feldtkeller, A., Identitatätssuche des syrischen Urchristentums: Mission, Inkulturation und Pluralität im ältesten Heidenchristentum (Gottingen, 1993).

Fiey, J.M., "Maruta de Martyropolis d'aprés Ibn al-Azraq (? 1181)," Analecta Bollandiana 94 (1976) 35-45.

Frye, R., "Notes on the Early Sasanian State and Church," in G. Furlani (ed.), Studi orientalistici in onore di G. L. Della Vida (Rome, 1956) pp. 314-345.

Frye, R., "Political History of Iran under the Sasanians," in E. Yarshater (ed.), Cambridge History of Iran, vol. 3 (Cambridge, 1983) pp. 116-177.

Gagé, J. and G. Walter, La montée des Sassanides et l'heure de Palmyre (Paris, 1964).

Garsoian, N., The Epic Histories Attributed to P'awstos Buzand (Cambridge, MA, 1989).

Garsoian, N., L'église Arménienne et le grand schisme d'Orient (Louvain, 1999).

Gatier, P.-L., "La christianisation de l'Antiochène dans l'Antiquité tardive," in E. Brads, B. Aitken, and J.M. Fossey (eds.), The Levant: Crossroads of Late Antiquity. History, Religion and Archaeology (Montreal, 2014) pp. 145-163.

Gero, S., Barsauma of Nisibis and Persian Christianity in the Fifth Century (Leuven, 1981).

Gignoux, P., Les quatre inscriptions du Mage Kirdir (Paris, 1991).

Greatrex, G., "The Two Fifth-Century Wars between Rome and Persia," Florilegium 12 (1993) 1-14.

Harrak, A., The Acts of Mâr Mârî the Apostle (Atlanta, 2005).

Holum, K., "Pulcheria's Crusade A.D. 421-22 and the Ideology of Imperial Victory," Greek, Roman and Byzantine Studies 18 (1977) 153-174.

Holum, K., Theodosian Empresses: Women and Imperial Dominion in Late Antiquity (Berkeley, California, 1982).

Honigmann, E. and A. Maricq, Recherches sur les Res Gestae divi Saporis (Brussels, 1953).

Howard-Johnston, J., "State and Society in Late Antique Iran," in V. Curtis and S. Stewart (eds.), The Sasanian Era (2008) pp. 118-129.

Jullien, F., "Le monachisme chrétien dans l'empire Iranien (IVe-XIVe Siècles)," in R. Gyeselen (ed.), Chrétiens en terre d'Iran (Paris, 2006) vol. 1, pp. 143-184.

Kawerau, P. and T. Kroll (trans.), The Chronicle of Arbela (Louvain, 1985).

Laird, R., "John Chrysostom and the Anomoeans: Shaping an Antiochene Perspective on Christology," in W. Mayer and B. Neil (eds.), Religious Conflict from Early Christianity to the Rise of Islam (Berlin, 2013) pp. 129-150. 
Liebeschuetz, J.H.G., "Epigraphic Evidence on the Christianisation of Syria," in J. Fitz (ed.), Limes: Akten des XI. Internationalen Limeskongresses (Székesfehérvár, 1976) pp. 485-508.

Liebeschuetz, J.H.G., "Problems Arising from the Conversion of Syria," in D. Baker (ed.), The Church in Town and Countryside (Oxford, 1979) pp. 17-24.

Lieu, S.N.C., "Captives, Refugees and Exiles: A Study of Cross-Frontier Civilian Movements and Contacts between Rome and Persia from Valerian to Jovian," in P. Freeman and D. Kennedy (eds.), The Defence of the Roman and Byzantine East (Oxford, 1986) pp. 475-505.

Malingrey, A.-M., Jean Chrysostome. Lettres à Olympias (Paris, 1968).

Marcus, R., "The Armenian Life of Marutha of Maipherkat," Harvard Theological Review 25 (1932) 47-71.

Marval, P. (ed.), Egérie. Journal de voyage (Paris, 1982).

Mayer, W., "John Chrysostom the Bishop: The View from Antioch," Journal of Ecclesiastical History 55.3 (2004) 455-466.

Mayer, W. and P. Allen, The Churches of Syrian Antioch (300-638 CE) (Leuven, 2012).

McDonough, S., "A second Constantine? The Sasanian King Yazdgard in Christian History and Historiography," Journal of Late Antiquity 1.1 (2008) 127-141.

Millar, F., "Christian Monasticism in Roman Arabia at the Birth of Mahomet," Semitica et Classica 2 (2009) 97-115.

Neusner, J., A History of the Jews in Babylonia, vol. 5 (Leiden, 1970).

Noret, J., "La Vie grecque ancienne de S. Maruta de Mayferkat," Analecta Bollandiana 91 (1973) 77-103.

Payne, R. and M. Soroush (eds.), The Archaeology of Sasanian Politics (Berlin, 2014).

Pourshariati, P., Decline and Fall of the Sasanian Empire (London, 2009).

Price, R.M. (trans.), A History of the Monks in Syria (Collegeville, MN, 1985).

Rubin, Z., "Diplomacy and War in the Relations between Byzantium and the Sassanids in the Fifth Century AD," in P. Freeman and D. Kennedy (eds.), The Defence of the Roman and Byzantine East (Oxford, 1986) pp. 677-695.

Russell, J., Zoroastrianism in Armenia (Cambridge, MA, 1987).

Sako, L., Le rôle de la hiérarchie Syriaque orientale dans les rapports diplomatiques entre la Perse et Byzance aux VE-VII ${ }^{e}$ siècles (Paris, 1986).

Schwartz, E., Kyrillos von Skythopolis, Texte und Untersuchungen (Leipzig, 1939).

Shahid, I., Byzantium and the Arabs in the Fifth Century (Washington, DC, 1989).

Shaked, S., "Religion in the Late Sasanian Period: Eran, Aneran, and other Religious Designations," in V. Curtis and S. Stewart (eds.), The Sasanian Era (London, 2008).

Smith, K., "Constantine and Judah Maccabee: History and Memory in the Acts of the Persian Martyrs," Journal of the Canadian Society for Syriac Studies 12 (2012) 16-33.

Stanfill, J., Embracing the Barbarian: John Chrysostom's Pastoral Care of the Goths (New York, 2015).

Tchalenko, G., Villages antiques de la Syrie du Nord: Le Massif du Bélus à l'époque romaine (Paris, 1953).

Trombley, F., Hellenic Religion and Christianization c. 370-529, 2 vols. (Leiden, 1993-4).

Van Dam, R., "From Paganism to Christianity in Late Antique Gaza," Viator 16 (1985) $1-20$.

Van Rompay, L., "L'informateur syrien de Basile de Césarée: à propos de Genèse 1,2," Orientalia Christiana Periodoca 58 (1992) 245-251.

Vööbus, A., The Canons Ascribed to Maruta of Maipherkat (Leuven, 1982).

Widengren, G. (L. Jospin, trans.), Les religions de l'Iran (Paris, 1968). 
Wiesehöfer, J., “'Geteilte Loyalitäten': Religiöse Minderheiten des 3. Und 4. Jahrhunderts n. Christ im Spannungsfeld zwischen Rom und dem sasanidischen Iran," Klio 75 (1993) 362-382.

Yannoulatos, A., "Monks and Mission in the Eastern Church During the Fourth Century," International Review of Missions 50 (1969) 208-228.

Barnes, T.D., "Constantine and the Christians of Persia," Journal of Roman Studies 75 (1986) 126-136.

Brock, S., "Christians in the Sasanian Empire: A Case of Divided Loyalties," Studies in Church History 17 (1982) 1-19.

Brock, S., 'L'église de l'Orient dans l'empire sassanide jusqu'au VI'e siècle et son absence aux conciles de l'Empire romain," Istina 40 (1995), pp. 25-43.

Christensen, A., Le règne de Kawâdh I et le communisme mazdakite (Copenhagen, 1929).

Debié, M., "Nisibe sauvée des eaux: les sources de Théodoret et la place des version syriaques," in B. Caseau (ed.), Pèlerinages et lieux saints dans l'Antiquité et le Moyen Âge: Mélanges offerts à Pierre Maraval (Paris, 2006) pp. 135-151.

Decret, F., "Les conséquences sur le christianisme en Perse de l'affrontement des empires romain et sassanide: de Shâpûr I ${ }^{\mathrm{er}}$ à Yazdgard I ${ }^{\mathrm{er}}$," Études augustiniennes 14 (1979) 91-152.

Dunn, G.D., "Flavius Constantius, Galla Placidia, and the Aquitanian Settlement of the Goths," Phoenix 69.3/4 (2015) 376-393.

Edwell, P., "Osrhoene and Mesopotamia between Rome and Arsacid Parthia," in J.M. Schlude and B.B. Rubin (eds.), Arsacids, Romans and Local Elites (Oxford, 2017) pp. 111-135.

Festugière, A.-J., Les moines d'orient III/1: Les moines de Palestine (Paris, 1962).

Fiano, E., "The Trinitarian Controversies in Fourth-Century Edessa," Le Muséon 128.1-2 (2015) 85-125.

Fiey, J.M., "Les communautés syriaques en Iran des premiers siècles à 1552," Acta Iranica 3 (1974) 279-297.

Frendo, D., "Constantine's Letter to Shapur II, its Authenticity, Occasion, and Attendant Circumstances," Bulletin of the Asia Institute, New Series 15 (2001) 57-69.

Garsoian, N., Church and Culture in Early Medieval Armenia (Surrey, 1999).

Geary, P., "Barbarians and Identity," in G.W. Bowersock, P. Brown, and G. Grabar (eds.), Late Antiquity: A Guide to the Postclassical World (Cambridge, MA, 1999) pp. 107-129.

Geary, P., "Political Identity, Ethnic Identity, Genetic Identity: The Dangers of Conceptual Confusion," in W. Pohl, M. Diesneberger, and B. Zeller (eds.), Neue Wege der Frühmitterlalterforschung - Bilanz und Perspectiven (Vienna, 2018) pp. 35-41.

Gignoux, P., "À la frontière du syriaque et de l'iranien: quelques confluences tirées des Actes des martyrs perses," Semetica Classica 3 (2010) 189-193.

Greenwood, T., "Armenia," in S. Johnson (ed.), Oxford Handbook of Late Antiquity (Oxford, 2012) pp. 115-141.

Griffith, S., "Ephraem, the Deacon of Edessa, and the Church of the Empire," in T. Halton and J. Willman (eds.), Diakonia: Studies in Honor of Robert T. Meyer (Washington, 1986) pp. 22-52.

Griffith, S., "The Doctrina Addai as a Paradigm of Christian Thought in Edessa in the Fifth Century," Hugoye: Journal of Syriac Studies 6.2 (2009) 269-292.

Gyselen, R., "Les témoignages sigillographiques sur la présence chrétienne dans l'empire Sassanide," in R. Gyselen (ed.), Chrétiens en terre d'Iran: implantation et acculturation, Studia Iranica, Cahier 33, Chrétiens en terre d'Iran, vol. 1 (Paris, 2006) pp. 17-78. 
Harvey, S., "Embodiment in Time and Eternity: A Syriac Perspective," St. Vladimir's Theological Quarterly 43.2 (1999) 105-125.

Holum, K., "Pulcheria's Crusade A.D. 421-22 and the Ideology of Imperial Victory," Greek, Roman and Byzantine Studies 18 (1977) 153-172.

Howard, G., The Teaching of Addai: Texts and Translations (Chico, CA, 1981).

Jullien, C., "La minorité chrétienne 'Grecque' en terre d'Iran à l'époque Sassanide," in R. Gyselen (ed.), Chrétiens en terre d'Iran: implantation et acculturaton, Studia Iranica, Cahier 33, Chrétiens en terre d'Iran, vol. 1 (Paris, 2006) pp. 105-142.

Lenski, N., "The Date of the Gothic Civil Wars and the Date of the Gothic Conversion," Greek Roman and Byzantine Studies 36.1 (1995) 51-87.

Lenski, N., Failure of Empire: Valens and the Roman State in the Fourth Century A.D. (Berkeley, 2002).

Liebeschuetz, J.H.W.G., Barbarians and Bishops: Army, Church, and State in the Age of Arcadius and Chrysostom (Oxford, 1992).

Lieu, S.N.C., "Captives, Refugees and Exiles: A Study of Cross-Frontier Civilian Movements and Contacts between Rome and Persia from Valerian to Jovian," in P. Freeman and D. Kennedy (eds.), The Defence of the Roman and Byzantine East (Oxford, 1986) pp. 475-505.

Looijenga, T., Texts and Contexts of the Oldest Runic Inscriptions (Leiden, 2003).

Nöldeke, T., Geschichte der Perser und Araber zur Zeit der Sasaniden aus der arabischen Chronik des Tabari (Leiden, 1879).

Payne, R.E., A State of Mixture: Christians, Zoroastrians, and Iranian Political culture in Late Antiquity (Berkeley, 2015).

Pohl, W., "Aux origines d'une Europe ethnique: transformations d'identités entre Antiquité et Moyen Âge," Annales HSS 1 (2005) 183-208.

Rapp, S., The Sasanian World through Georgian Eyes: Caucasia and the Iranian Commonwealth in Late Antique Georgian Literature (London, 2014).

Russell, P., "Nisibis as the Background to the Life of Ephrem the Syrian," Hugoye 8 (2005) 179-235.

Scardigli, P., "Neuentdeckte gotische Sprachreste," in W. Streitberg and P. Scardigli (eds.), Die gotische Bibel, Band 3 (Heidelberg, 2000) pp. 500-522.

Scopello, M., "Un témoin de la controverse religieuse entre Chrétiens et Manichéens aux frontières de l'Iran: Les Acta Archelai," in C. Jullien (ed.), Controverses des Chrétiens dans l'Iran sassanide (Paris, 2008) pp. 147-168.

Seleznyov, N.N., "Nestorius of Constantinople: Condemnation, Suppression, Veneration," Journal of Eastern Christian Studies 62.3-4 (2010) 165-190.

Shahid, I., Byzantium and the Arabs in the Fifth Century (Washington, DC, 1989).

Smith, K., "Constantine and Judah the Maccabee: History and Memory in the Acts of the Persian Martyrs," Journal of the Canadian Society for Syriac Studies 12 (2012) 16-33.

Smith, K., Constantine and the Captive Christians of Persia: Martyrdom and Religious Identity in Late Antiquity (Berkeley, 2016).

Smith, R., "The Casting of Julian the Apostate 'in the Likeness' of Alexander the Great: A Topos in Antique Historiography and its Modern Echoes," Histos 5 (2011) 44-106.

Swain, B., "Goths and Gothic Identity in the Ostrogothic Kingdom," in J.J. Arnold, M. Shane Bjornlie, and K. Sessa (eds.), A Companion to Ostrogothic Italy (Leiden, 2016) pp. 203-233.

Trombley, F., Hellenic Religion and Christianization c. 370-529, 2 vols. (Leiden, 1993-4).

Walker, J., The Legend of Mar Qardagh (Berkeley, CA, 2006). 
Wood, P., "Syriac and the Syrians," in S. Johnson (ed.), Oxford Handbook of Late Antiquity (Oxford, 2012) pp. 170-194.

Zuckerman, C., "Heraclius and the Return of the Holy Cross," in C. Zuckerman (ed.), Constructing the Seventh Century (Paris, 2013) pp. 197-218.

Anfray, A., A. Caquot, and P. Nautin, "Une nouvelle inscription grecque d'Ezana, roi d'Axoum," Journal des savants (1970) 260-274.

Antonopoulos, P.T., "The Less Obvious Ends of Byzantine Diplomacy," in J. Shepard and S. Franklin (eds.), Byzantine Diplomacy (Aldershot, 1992) pp 315-320.

Bâfaqîh, M., L'unification du Yémen antique: la lutte entre Saba', Himyar et le Hadramawt du Ier au IIlème siècle de l'ère Chrétienne (Paris, 1990).

Battistoni, F., "Retori e ambasciatori dall'ellenismo al tardo imperio," in A. Becker and N. Drocourt (eds.), Ambassadeurs et ambassades au coeur des relations diplomatiques (Metz, 2012) pp. 127-141.

Becker, A., "La girafe et la clepsydre: offrir des cadeaux diplomatiques dans l'Antiquité tardive," Monde 5 (2014a) 27-42.

Becker, A., "Les évêques et la diplomatie Romano-barbare en Gaule au Ve siècle," in M. Gaillard (ed.), L'empreinte chrétienne en Gaule, du IVe au IXe siècle (Brepols, 2014b) pp. 45-60.

Becker, A., "Les modalités pratiques de la diplomatie romano-barbare dans le Code Théodosien," Quaderni camerti di studi romanistici 43 (2015) 103-117.

Becker A. and N. Drocourt (eds.), Ambassadeurs et ambassades au coeur des relations diplomatiques: Rome-Occident médiéval-Byzance (VIIIe s. avant J.-C. -XIIe s. après J.-C.) (Metz, 2012).

Bérenger, A., "Être ambassadeur, une mission à hauts risques?" in A. Becker and N. Drocourt (eds.), Ambassadeurs et ambassades au coeur des relations diplomatiques (Metz, 2012) pp. 83-100.

Bland, R., "Gold for the Barbarians? Uniface Gold Medallions of the House of Constantine Found in Britain and Ireland," Britannia 43 (2012) 217-225.

Blockley, R., East Foreign Policy. Formation and Conduct from Diocletian to Anastasius (Leeds, 1992).

Bowersock, G., "Mavia Queen of the Saracens," in W. Eck, H. Galsterer, and H. Wolff (eds.), Studien zur antiken Sozialgeschichte: Festschrift Friedrich Vittinghoff (Vienna, 1980) pp. 477-495.

Chauvot, A., "Legatio, clientèle et munera. À propos d'Ammien Marcellin XXVI,5,7," in A. Becker and N. Drocourt (eds.), Ambassadeurs et ambassades au coeur des relations diplomatiques (Metz, 2012) pp. 143-166.

Chrysos, E., "Legal Concepts and Patterns for the Barbarians' Settlement on Roman Soil," in E. Chrysos and A. Schwarcz (eds.), Das Reich und die Barbaren (Vienna, 1989) pp. 13-23.

Chrysos, E., "Byzantine Diplomacy, AD 300-800: Means and Ends," in J. Shepherd and S. Franklin (eds.), Byzantine Diplomacy (London, 1992) pp. 25-40.

de Francisco Heredero, A., "Synesios of Cyrene and the Defence of Cyrenaica," in A. de Francisco Heredero, D. Hernández de la Fuente, and S. Torres Prieto (eds.), New Perspectives on Late Antiquity in the Eastern Roman Empire (Cambridge, 2014) pp. 163-190.

Delaplace, C., "La diplomatie de l'Empire romain dans l'antiquité tardive," in A. Becker and N. Drocourt (eds.), Ambassadeurs et ambassades au coeur des relations diplomatiques (Metz, 2012) pp. 167-181. 
Deliyannis, D., H. Dey, and P. Squatriti, “The Hormizd Plate, Persia, Fifth-Sixth Century,” in D. Deliyannis, H. Dey, and P. Squatriti (eds.), Fifty Early Medieval Things (Ithaca, NY, 2019) pp. 58-61.

Dolet, E. (D. Amherdt, ed.), De officio legati, De immunitate legatorum, De legationibus Ionnis Langiachi Episcopi Lemovicensis (Geneva, 2010).

Eck, W., "Diplomacy as Part of the Adminstrative Process," in C. Eilers (ed.), Diplomats and Diplomacy in the Roman World (Leiden, 2009) pp. 192-207.

Eilers, C. (ed.), Diplomats and Diplomacy in the Roman World (Leiden, 2009).

Finkelstein, L.S., "Remembering Ralph Bunche," World Policy Journal 20.3 (2003) 70-73.

Helm, R., "Untersuchungen über den auswärtigen diplomatischen Verkehr des römischen Reiches im Zeitalter der Spätantike," Archiv für Urkundenforschung 12 (1932) 375-436.

Hercher, R. (ed.), Epistolographi Graeci (Paris, 1873).

Isaac, B., The Limits of Empire: The Roman Army in the East (Oxford, 1990).

Jal, P., "Place et rôle des legati et legationes dans le récit livien," Revue des Études Latines 63 (1985) 118-131.

Lee, A.D., Information and Frontiers: Roman Foreign Relations in Late Antiquity (Cambridge, 1993).

Lee, A.D., "Abduction and Assassination: The Clandestine Face of Roman Diplomacy in Late Antiquity," The International History Review 31.1 (2009) 1-23.

Mathisen, R.W., "Patricii, Episcopi, et Sapientes: Le choix des ambassadeurs pendant l'antiquité tardive dans l'empire romain et les royaumes barbares," in A. Becker and N. Drocourt (eds.), Ambassadeurs et ambassades au coeur des relations diplomatiques (Metz, 2012) pp. 227-238.

Nechaeva, E., "Les activités secrètes des ambassadeurs dans l'antiquité tardive," in A. Becker and N. Drocourt (eds.), Ambassadeurs et ambassades au coeur des relations diplomatiques (Metz, 2012) pp. 183-202.

Nechaeva, E., Embassies - Negotiations - Gifts: Systems of East Roman Diplomacy in Late Antiquity (Stuttgart, 2014).

Nöldeke, T., Geschichte der Perser und Araber zur Zeit der Sasaniden aus der arabischen Chronik des Tabari (Leiden, 1879).

Pigulevskaia, N., Vizantiia na putiakh v Indiu: iz istorii torgovli Vizantii s Vostokom v IV-VI vv. (Moscow, 1951) [German translation: Byzanz auf den Wegen nach Indian: Aus der Geschichte des byzantinischen Handels mit dem Orient vom 4. Bis 6. Jahrhundert (Berlin, 1969)].

Potts, D.T., The Arabian Gulf in Antiquity (Oxford, 1990).

Robin, C., "Judaïsme et christianisme en Arabie du Sud d'après les source épigraphiques et archéologiques," Proceedings of the Seminar for Arabian Studies 10 (1980) 85-96.

Smith, S., "Events in Arabia in the 6th Century A.D.," Bulletin of the School of Oriental and African Studies 16 (1954) 425-468.

Stein, P., "The 'Himyaritic' Language in pre-Islamic Yemen: A Critical Re-evaluation," Semetica et Classica 1 (2008) 203-212.

Stouder, G., "Des manuels de diplomatie à l'usage du légat romain?" in A. Becker and N. Drocourt (eds.), Ambassadeurs et ambassades au coeur des relations diplomatiques (Metz, 2012) pp. 11-29.

Swade, D.D., "Redeeming Charles Babbage's Mechanical Computer," Scientific American 268.2 (1993) 86-91.

Tobi, Y., "The Jews of Yemen in Light of the Excavation of the Jewish Synagogue in Qan̄̄'," Proceedings of the Seminar for Arabian Studies 43 (2013) 349-356. 
Toole, B.A., Ada, the Enchantress of Numbers (Moreton-on-Marsh, 1993).

Trania, G., "L'ambassade de l'Arménien Nersēs/Narseus (a. 358)," in A. Becker and N. Drocourt (eds.), Ambassadeurs et ambassades au coeur des relations diplomatiques (Metz, 2012) pp. 203-209.

Treadgold, W., "The Diplomatic Career and Historical Work of Olympiodorus of Thebes," The International History Review 26.4 (2004) 709-733.

Trimingham, J.S., "Mawiyya: The First Christian Arab Queen," The Near East School of Theology Theological Review 1.1 (1978) 3-10.

Whitby, M., "Byzantine Diplomacy: Good Faith, Trust and Co-operation in international Relations in Late Antiquity," in P. De Souza and J. France (eds.), War and Peace in Ancient and Medieval History (Cambridge, 2008) pp. 120-140.

Woods, D., "The Saracen Defenders of Constantinople in 378," Greek Roman and Byzantine Studies 37 (1996) 259-279.

Woods, D., "Maurus, Mavia, and Ammianus," Mnemosyne 51.3 (1998) 325-336.

Yule, P., Spätantike im Jemen/Late Antique Yemen (Aichwald, 2007).

Altheim, F., Geschichte der Hunnen (Berlin, 1961).

Bertinelli, A., "Al confine tra l'impero romano e la Persia in età tardoantica; la questione della Lazica," Quaderni catanesi di studi classici e medievali 1 (1989) 117-146.

Bowersock, G., "Nonnosus and Byzantine Diplomacy in Arabia," Rivista storica italiana 124.1 (2012) 282-291.

Braund, D., "Procopius on the Economy of Lazica," Classical Quarterly 41.1 (1991) 221-225.

Braund, D., Georgia in Antiquity (Oxford, 1994).

Charles, R.H. (trans.), The Chronicle of John, Bishop of Nikiu (London, 1916).

Cross, S.H. and O.P. Sherbowitz-Wetzor (eds. and trans.), The Russian Primary Chronicle, Laurentian Text (Cambridge, MA, 1930).

Curta, F., "Ethnicity in the Steppe Lands of the Northern Black Sea Region During the Early Byzantine Times," Archaeologia Bulgarica 23.1 (2019) 1-38.

Darrouzès, J., Notitiae episcopatuum ecclesiae Constantinopolitaniae (Paris, 1981).

Diesner, H.J., "Jugend und Mönchtum des Fulgentius,” Helikon 1 (1961) 677-685.

Dură, N.V., "Christianism in Pontic Dacia: The 'Scythian Monks' (Daco-Roman) and the Contribution to the Advance of Ecumenical Unity and the Development of the European Christian Humanist Culture," Revue roumaine d'histoire 42 (2003) 5-17.

Edwards, D.N., "Post-Meroitic ('X-Group') and Christian Burials at Sesibi, Sudanese Nubia. The excavations of 1937," Journal of Egyptian Archaeology 80 (1994) 159-178.

Engelhardt, I., Mission und Politik in Byzanz (Munich, 1974).

Featherstone, M., "Olga's Visit to Constantiople," Harvard Ukrainian Studies 14 (1990) 293-312.

Featherstone, M., "Olga's Visit to Constantinople in De Ceremoniis," Revue des études byzantines 61 (2003) 241-251.

Frye, R., "Political history of Iran under the Sasanians," in E. Yarshater (ed.), Cambridge History of Iran, vol. 3 (Cambridge, 1983) pp. 116-177.

Greatrex, G., Rome and Persia at War, 502-532 (Leeds, 1998).

Grossman, P., "Die Kirche des Bischofs Theodorus im Isistempel von Philae. Versuch einer Rekonstruction," Rivisti degli Studi Orientali 58 (1987) 107-111.

Kirwan, L.P., "The Birth of Christian Nubia: Some Archaeological Problems," Rivista degli Studi Orientali 58 (1987) 119-134. 
Kresten, O., 'Staatsempfänge' im Kaiserpalast von Konstantinoplel um die Mitte des 10. Jahrhunderts (Vienna, 2000).

Kruse, M., "The Speech of the Armenians in Procopius: Justianian's Foreign Policy and the Transition between Books 1 and 2 of the Wars," Classical Quarterly 63.2 (2013) 866-881.

Lapeyre, P.G.-G. (ed.), Vie de saint Fulgence de Ruspe (Paris, 1929).

Liebeschuetz, J.H.W.G., "Gens into Regnum: The Vandals," in H.-W. Goetz, J. Jarnut, and W. Pohl (eds.), Regna and Gentes: The Relationship between Late Antique and Early Medieval Peoples and Kingdoms in the Transformation of the Roman World (Leiden, 2003) pp. 55-84.

Merrills, A. and R. Miles, The Vandals (Oxford, 2010).

Momigliano, A., "Pagan and Christian Historiography in the Fourth Century A.D.," in A. Momigliano (ed.), Pagansm and Christianity in the Fourth Century (Oxford, 1963) pp. 79-99.

Nautin, P., "La conversion du temple de Philae en église chrétienne," Cahiers archéologiques 17 (1967) 1-43.

Noonan, T.S., "The Khazar Qaghanate and Its Impact on the Early Rus' State: The translatio imperii from Itil to Kiev," in A.M. Khazanov and A. Wink (eds.), Nomads in the Sedentary World (Richmond, England, 2001) pp. 76-102.

Pigulevskaya, N.V., "Les rapports sociaux a Nedjran au début du VI ${ }^{\mathrm{e}}$ siecle de l'ère chrétienne, I," Journal of the Economic and Social History of the Orient 3 (1960) 113-130.

Pigulevskaya, N.V., "Les rapports sociaux a Nedjran au début du VI ${ }^{\mathrm{e}}$ siecle de l'ère chrétienne, I," Journal of the Economic and Social History of the Orient 4 (1961) 1-14.

Raffensperger, C., "Rusian Economic and Marital Policy: An Initial Analysis of Correlations," Russian History 34 (2007) 149-159.

Robin, C.J., "Nagran vers l'époque du massacre: notes sur l'histoire politique, économique, et institutionnelle et sur l'introduction du Christianisme," in J. Beaucamp, F. BriquelChatonnet, and C.J. Robin (eds.), Juifs et chrétiens en Arabie aux Ve et VIe siècles: regards croisés sur les sources (Paris, 2010) pp. 42-106.

Seibt, W., "Westgeorgien (Egrisi, Lazica) in früchristlicher Zeit," in R. Pillinger, A. Pülz, and H. Vetters (eds.), Die Schwarzmeerküste in der Spätantike und im frühen Mittelalter (Vienna, 1992) pp. 137-144.

Shahid, I., "Byzantino-Arabica: The Conference of Ramla, A.D. 524," Journal of Near Eastern Studies 23.2 (1964) 115-131.

Shinnie, P.L., Ancient Nubia (London, 1996).

Smith, S., "Events in Arabia in the 6th century A.D.," Bulletin of the School of Oriental and African Studies 16 (1954) pp. 425-468.

Snaedal, M., "The 'Vandal' Epigram," Filologia Germanica - Germanic Philology 1 (2009) 181-214.

Thurn, I., Ioannis Malalae Chronographia (Berlin, 2000).

Török, L., Late Antique Nubia (Budapest, 1988).

Treadgold, W., "World Histories of John Malalas and Eustathius of Epiphania," The International History Review 29.4 (2007) 709-745.

Vasiliev, A.A., Justin the First: An Introduction to the Epoch of Justinian the Great (Cambridge, MA, 1950).

Vernadsky, G., "The Eparchy of Gothia," Byzantion 15 (1941) 67-76.

Welsby, D.A., The Medieval Kingdoms of Nubia (London, 2002).

Zakaraia, P.V., A. Lekvinadze, and N. Lomouri, "Fouilles de Nokalakévi Archéopolis. Résumé," Bedi Kartlisa 37 (1979) 194-202. 
Zuckerman, C., "Le voyage d'Olga et la première ambassade espagnole à Constantinople en 946," Travaux et Mémoires 13 (2000) 647-672.

Zurawski, B., "Medieval Nubian Regalia: Innovation versus Tradition," in D. Welsby (ed.), Recent Research in Kushite History and Archaeology: Proceedings of the Eight International Conference of Meroitic Studies (London, 1999) pp. 223-234.

Zurawski, B. and M. el-Tayeb, "The Christian Cemetery of Jebel Ghaddar North," Nubica 3.1 (1994) 297-317. 